\title{
Intellectual Property Rights and Standard-Setting Organizations
}

\author{
Mark A. Lemley†
}

\section{TABLE OF Contents}

Introduction

I. The Nature and Importance of Standard-Setting Organizations ..... 1896

A. The Value of Standardization ................................................1896

B. Organizational Forms of Standardization ................................ 1898

C. The Relationship of Standardization to Intellectual Property ... 1901

II. How Standard-Setting Organizations Treat Intellectual Property

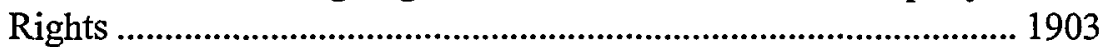

A. Organizations Studied.............................................................. 1903

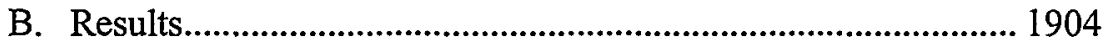

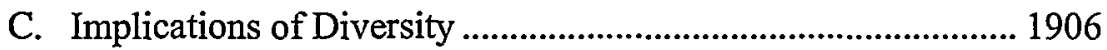

III. The Enforceability of Standard-Setting Organization Rules

Restricting Intellectual Property.................................................. 1909

A. Standard-Setting Organization Intellectual Property Rules

as Creatures of Contract Law................................................. 1909

1. Are Bylaws Binding Contracts? ......................................... 1909

2. The Effect of Withdrawal............................................... 1912

3. Parsing the Terms of Standard-Setting Organization

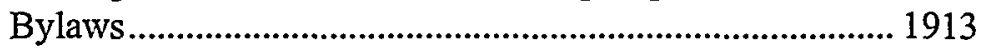

4. Enforcement of Bylaws as Contracts .............................. 1914

Q 2002 Mark A. Lemley.

$\dagger$ Professor of Law, School of Law, University of California, Berkeley (Boalt Hall); of counsel, Keker \& Van Nest, San Francisco, California. Thanks to Oracle and ANSI for a generous grant supporting this project; to Robert Barr, Erv Basinski, Bernie Black, Steve Calkins, Carl Cargill, Julie Cohen, William Cohen, John Danforth, Aaron Edlin, Bob Glushko, Jennifer Gray, Rose Hagan, Mark Janis, Jay Kesan, Ed Kitch, Michael Klausner, Amy Marasco, David McGowan, Rob Merges, Janice Mueller, Peggy Radin, Pam Samuelson, Josh Sarnoff, Carl Shapiro, Howard Skaist, Bob Skitol, Jeff Strnad, Phil Weiser and participants at the Telecommunications Policy Research Conference, the Berkeley Patent System Reform Conference, the Oracle/ANSI Conference on standard setting at George Washington University, the FTC-DOJ hearings on IP and antitrust, the Bay Area Group on Economics and Law, and workshops at Stanford Law School and the Georgetown University Law Center for comments on an earlier draft or other helpful discussions; to Colleen Chien, Ryan Garcia, and Laura Quilter for research assistance; and to the Open Group, Sun Microsystems, Erv Basinski and Carl Cargill for helping me navigate the morass of standard-setting organizations in computer networking. 


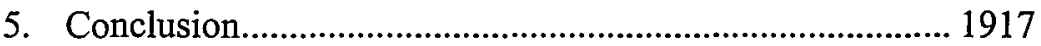

B. Enforceability Under Intellectual Property Law....................... 1918

1. Disclosure Obligations and Equitable Estoppel ................. 1918

a. Application to Standard-Setting Organization Rules... 1919

b. Application Outside of Standard-Setting

Organizations.

2. Reasonable and Nondiscriminatory Licensing

Obligations and Implied License.

C. Tort Liability for Nondisclosure of Intellectual Property ......... 1927

1. Antitrust Theories of Liability...........................................1927

2. Common Law Alternatives to Antitrust ........................... 1935

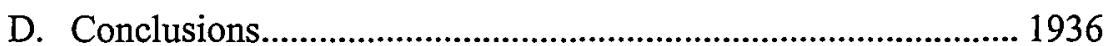

IV. Antitrust Limits on Standard-Setting Organization Intellectual Property Rules

A. Intellectual Property as Procompetitive .................................. 1938

B. Joint-Defense Agreements as Licensee Cartels ........................ 1939

C. Standard-Setting Organization Rules Restricting Intellectual

Property as Antitrust Violations ............................................. 1943

1. Disclosure Requirements............................................... 1943

2. Royalty-Free or Compulsory Licensing Requirements...... 1944

D. Conclusions

V. Standard-Setting Organization Intellectual Property Rules as Private Ordering in the Shadow of Patent Law ............................... 1948

A. Intellectual Property Rules as Efficient Private Ordering......... 1948

B. The Reality of "Messy" Private Ordering................................ 1954

VI. Designing Optimal Standard-Setting Organization Policies ............ 1957

A. Optimizing Standard-Setting Organization Intellectual

Property Rules: Suggestions for Organizations and

Members ............................................................................ 1957

1. Define the Intellectual Property Rights in Question.......... 1957

2. Take Process Seriously.................................................. 1960

3. Eschew Disclosure-Only Policies .................................... 1960

4. Decide Where Your Organization Falls on the Open-Closed Continuum.................................................. 1962

5. Permit Licenses that Control Fragmentation...................... 1963

6. Give Content to the Reasonable and Nondiscriminatory Licensing Requirement

7. Require Members to Evaluate and Comply with the

Standard-Setting Organization's Policy

B. Implications for Policy Makers............................................ 1968

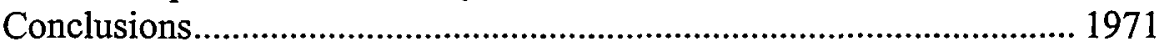

Appendix. 


\title{
Intellectual Property Rights and Standard-Setting Organizations
}

\author{
Mark A. Lemley
}

Standard-setting organizations ("SSOs") regularly encounter situations in which one or more companies claim to own proprietary rights that cover a proposed industry standard. The industry cannot adopt the standard without the permission of the intellectual property ("IP") owner (or owners). How SSOs respond to those who assert IP rights is critically important. Whether or not private companies retain IP rights in group standards will determine whether a standard is "open" or "closed." It will determine who can sell compliant products, and it may well influence whether the standard adopted in the market is one chosen by a group or one offered by a single company. SSO rules governing $I P$ rights will also affect how standards change as technology improves.

Given the importance of SSO rules governing IP rights, there has been surprisingly little treatment of SSO intellectual property rules in the legal literature. My aim in this article is to fill that void. To do so, I have studied the IP policies of dozens of SSOs, primarily but not exclusively in the computer networking and telecommunications industries. This is no accident; interface standards are much more prevalent in those industries than in other fields.

In the end, I hope to convince the reader of four things. First, SSO rules governing IP fundamentally change the way in which we must approach the study of IP. It is not enough to consider IP rights in a vacuum; we must consider them as they are actually used in practice. And that means considering how SSO rules affect IP incentives in different industries. Second, there is a remarkable diversity among SSOs in how they treat IP rights. This diversity is largely accidental, and does not reflect conscious competition between different policies. Third, the law must accommodate the modern role of SSOs. Antitrust rules may unduly restrict SSOs even when those organizations are serving procompetitive ends. And enforcement of SSO IP rules presents a number of important but unresolved problems of contract and IP law, issues that will need to be resolved if SSO IP rules are to fulfill their promise of solving patent holdup problems.

My fourth conclusion is an optimistic one. SSOs are a species of private ordering that may help solve one of the fundamental dilemmas of IP 
law: the fact that intellectual property rights seem to promote innovation in some industries but harm innovation in others. SSOs may serve to ameliorate the problems of overlapping IP rights in those industries in which IP is most problematic for innovation, particularly in the semiconductor, software, and telecommunications fields. The best thing the government can do is to enforce these private ordering agreements and avoid unduly restricting SSOs by overzealous antitrust scrutiny.

"Without standardization there wouldn't be a modern economy.""

\section{INTRODUCTION}

The standard economic theory of intellectual property ("IP") is well known. Intellectual creations are public goods that are much easier and cheaper to copy than they are to produce in the first place. Absent some form of exclusive right over inventions, no one (or not enough people) will bother to innovate. IP rights are thus a "solution" to the public-goods problem because they privatize the public good, giving potential inventors an incentive to engage in research and development. ${ }^{2}$

In the real world, things aren't so simple. People innovate for many reasons, and in many industries the existence of IP rights doesn't appear to be chief among them. ${ }^{3}$ IP rights have different impacts on different industries, depending on the nature and cost of innovation, the maturity of the industry, and the relationship between patentable inventions and marketable products. ${ }^{4}$ These different characteristics, coupled with uncertainty about how much incentive IP rights actually give, have led to vigorous debates about the wisdom of IP rights in particular contexts, notably software and electronic commerce. ${ }^{5}$

The effect of IP isn't just a matter of law, however, or even of private licensing deals. There is another sort of organization that mediates between IP owners and users. Standard-setting organizations ("SSOs") are industry groups that set common standards in a variety of significant areas.

1. James Surowiecki, Turn of the Century, WIRED, Jan. 2002, at 85 .

2. For a discussion of the standard theory, see Mark A. Lemley, The Economics of Improvement in Intellectual Property Law, 75 Tex. L. Rev. 989, 993-1000 (1997).

3. See, e.g., Richard C. Levin et al., Appropriating the Returns from Industrial Research and Development, 1987 Brookings Papers on Econ. Activity 783; Wesley M. Cohen, et al., Protecting Their Intellectual assets: Appropriability Conditions and Why U.S. Manufacturing Firms Patent (OR NOT) (Nat'l Bureau of Econ. Research, Working Paper No. W7552, 2000).

4. For an empirical demonstration of this, see John R. Allison \& Mark A. Lemley, The Growing Complexity of the United Statcs Patent System, 82 B.U. L. Rev. 77 (2002) (showing that patents are extremely heterogeneous across industries); Levin et al., supra note 3; COHEN ET AL., supra note 3.

5. See, e.g., Julie E. Cohen \& Mark A. Lemley, Patent Scope and Innovation in the Software Industry, 89 CaLif. L. Rev. 1 (2001); Pamela Samuelson et al., A Manifesto Concerning the Legal Protection of Computer Programs, 94 Colum. L. Rev. 2308 (1994). 
Telephones talk to each other, the Internet works, and hairdryers plug into electrical sockets because private groups have set "interface" standards, allowing compatibility between products made by different manufacturers. With such interface standards, it is important that different coinpanies can make products that comply with the standard. But SSOs increasingly encounter situations in which one or more companies claim to own proprietary rights that cover a proposed industry standard. ${ }^{6}$ This prevents the industry from adopting the standard without the permission of the IP owner or owners.

How SSOs respond to those who assert IP rights against a proposed standard is critically important. Whether or not a private company retains IP rights in a group standard will determine whether the standard is "open" or "closed." It will determine who can sell compliant products, and it may well influence whether the standard adopted in the market is one chosen by a group or one offered by a single company. SSO rules governing IP rights may also influence the incentives to develop new technologies and affect how standards change as technology improves. To give just one example of the importance of SSO IP rules, the Internet runs on a set of open, nonproprietary protocols in large part because the Internet Engineering Task Force ("IETF"), the SSO that controls the TCP and IP protocols, had a longstanding policy that it would not adopt proprietary standards. That policy has now changed. The World Wide Web Consortium ("W3C") also recently considered changing its policy to permit proprietary Web standards, prompting a firestorm of criticism. ${ }^{8}$ Assertions by IBM and Microsoft of patents that allegedly cover the ebXML and SOAP electronic-commerce protocols have also caused huge controversy in the Internet standards community. ${ }^{9}$ It remains to be seen whether the open nature of the Internet will

6. See, e.g., Ken Krechmer, Communications Standards and Patent Rights: Conflict or Coordination? 2 (2002) (draft working paper, on flle with author) ("The cost of patent rights for communications products is expanding ... patent claims and charges are rising, and negotiations over such matters often create delays in communications standards development worldwide.").

7. The new policy is available at The Internet Engineering Task Force, IETF Page of Intellectual Property Rights Notices, at http://www.ietf.org/ipr.html (last visited Nov. 12, 2002).

8. See, e.g., Janice Mueller, Patent Misuse Through the Capture of Industry Standards, 17 BERKELEY TECH. L.J. 623, 630 (2002) [hereinafter Mueller, Misuse] (describing this debate); Wade Roush, Web Tolls Ahead?, 105 TECH. REv. 20 (Jan/Feb. 2002). At this writing, the W3C appeared likely to adhere to its royalty-free patent-licensing policy. See Margaret Kane, W3C Retreats from Royalty Policy, CNET News.coin, at http://news.com.com/2100-1023-845023.html (Feb. 26, 2002).

9. See, e.g., David Berlind, IBM, Microsoft Plot Net Takeover, ENTERPRISE, available at $\mathrm{http} / /$ www.zdnet.com/filters/printerfriendly/0,6061,2861123-92,00.html (Apr. 11, 2002). IBM later backed down on its ebXML patent. See e-mail from Robert S. Sutor, Director, IBM e-business Standards Strategy, to the ebXML Joint Coordinating Committee, available at http://lists.ebxml.org/ archives/ebxml/200204/msg00004.html (Apr. 18, 2002 18:27 EST). 
survive this shift to proprietary standards, ${ }^{10}$ but in any event the magnitude of the stakes should be clear. Whether interface standards are open or closed depends in large part on the rules SSOs adopt and how those rules are enforced.

Given the importance of SSO rules that govern IP rights, they have received surprisingly little treatment in the legal literature until quite recently. ${ }^{11}$ In this Article I attempt to fill that void. To begin, I have studied the IP policies of dozens of SSOs, primarily but not exclusively in the computer-networking and telecommunications industries. My selection of these industries is no accident; interface standards are much more prevalent

10. For an argument that the Internet is moving in this direction, see LAWRENCE LESSIG, THE Future of IdeAs: The Fate of THE COMmons in a CONNECTEd World (2001).

11. The literature on antitrust and SSOs is voluminous, but most of it considers issues unrelated to IP. Among the better sources are James J. Anton \& Dennis A. Yao, Standard-Setting Consortia, Antitrust, and High-Technology Industries, 64 ANTiTRust L.J. 247, 248, 262-63 (1995); Jack E. Brown, Technology Joint Ventures to Set Standards or Define Interfaces, 61 ANTrTRust L.J. 921 (1993); Sean P. Gates, Standards, Innovation, and Antitrust: Integrating Innovation Concerns Into the Analysis of Collaborative Standard Setting, 47 EMORY L.J. 583 (1998); H.S. Gerla, Federal Antitrust Law and Trade and Professional Association Standards and Certification, 19 U. DAYTON L. Rev. 471 (1994); Jonathan T. Howe \& Leland Badger, The Antitrust Challenge to Non-Profit Certification Organizations: Conflicts of Interest and a Practical Rule of Reason Approach to Certification Programs as Industry-Wide Builders of Competition and Efficiency, 60 WASH. U. L.Q. 357 (1982) (endorsing a fact-specific rule-of-reason approach); Thomas M. Jorde \& David J. Teece, Rule of Reason Analysis of Horizontal Arrangements: Agreements Designed to Advance Innovation and Commercialize Technology, 61 AnTITRust L.J. 579 (I993); Mark A. Lemley, Antitrust and the Internet Standardization Problem, 28 CoNN. L. REv. 1041 (1996) [hereinafter Lemley, Internet Standardization]; Thomas A. Piraino, Jr., The Antitrust Analysis of Network Joint Ventures, 47 HaStings L.J. 5 (1995); Mark Shurmer \& Gary Lea, Telecommunications Standardization and Intellectual Property Rights: A Fundamental Dilemma?, in Standards Policy For Information INFRASTRUCTURE 378 (Brian Kahin \& Janet Abbate eds., 1995); David Teece, Information Sharing, Innovation, and Antitrust, 62 ANTITRust L.J. 465 (1994); Philip J. Wciser, Internet Governance, Standard Setting, and Self-Regulation, 28 N. KY. L. Rev. 822 (200I) [hereinafter Weiser, Internet Governance]; Melonie L. McKenzie, Note, How Should Competing Software Programs Marry? The Antitrust Ramifications of Private Standard-Setting Consortia in the Software Industry, 52 SYRAcuse L. REv. 139 (2002).

There have been a few recent articles that tackle the problem of SSOs and IP rights. See, e.g., Michael G. Cowie \& Joseph P. Lavelle, Patents Covering Industry Standards: The Risks to Enforceability Due to Conduct Before Standard Setting Organizations, 30 AIPLA Q.J. 95 (2002); Janice Mueller, Patenting Industry Standards, 34 J. MarSHALI L. Rev. 897 (2001) [hereinaftcr Mueller, Patenting Industry Standards]; Mark R. Patterson, Inventions, Industry Standards, and Intellectual Property, 17 Berkeley TECH. L.J. 1043 (2002); Michael J. Schallop, The IPR Paradox: Leveraging Intellectual Property Rights to Encourage Interoperability in the Network Computing Age, 28 AIPLA Q.J. 195 (2000); Carl Shapiro, Navigating the Patent Thicket: Cross Licensing, Patent Pools, and Standard Setting, in InNovation Policy AND the EConomy (Adam Jaffe et al., eds., Nat'1 Bureau of Econ. Research, 2001) [hereinafter Shapiro, Thicket]; Daniel J. Gifford, Developing Models for a Coherent Treatment of Standard-Setting Issues Under the Patent, Copyright and Antitrust Laws (Apr. 19, 2002) (draft working paper, on file with author). For less academic works, see Robert P. Feldman et al., The Effect of Industry Standard Setting on Patent Licensing and Enforcement, IEEE COMM., July 2000, at 112; Jason Kipnis, Beating the System: Abuses of the Standards Adoption Process, IEEE COMM., July 2000, at 102; ANDREW UPDEG ROVE, Is THERE A Need for Government Regulation of the Standard Setting Process?, at http://www.ftc.gov/opp/intellect/020418updegrovel.pdf (last visited Nov. 26, 2002). 
there than in other fields. ${ }^{12}$ In Part I, I provide some background on SSOs and discuss the value of group standard setting in network markets. In Part II, I discuss my empirical research, which demonstrates a remarkable diversity among SSOs, even within an imdustry, in how they treat IP rights. I argue that this diversity is largely accidental, and does not reflect conscious competition between different policies. In Part III, I analyze a host of unresolved contract, $\mathrm{IP}$, and antitrust law issues that relate to the applicability and enforcement of such IP policies. Enforcement of SSO IP rules presents a number of important but unsettled legal problems-issues that must be resolved if SSO IP rules are to fulfill their promise of solving patent holdup problems. In Part IV, I consider the constraints that the antitrust laws place on the ability of SSOs to adopt IP policies. Under current law, antitrust rules may unduly restrict SSOs even when those SSOs are serving procompetitive ends. Part V offers a theory of SSO IP rules as a sort of messy private ordering that allows companies to bargain around overlapping IP rights in those mdustries in which it is most important that they do so. SSO IP rules hold out the promise of efficient bargaining in the shadow of IP law, although the reality does not always match the theory. Finally, in Part VI I offer ideas for how the law and the SSOs themselves can improve the efficiency of this private-ordering process.

SSO rules governing IP fundamentally change the way in which we must approach the study of IP law. It isn't enough to consider IP rights in a vacuum; we must consider them as they are actually used in practice. And that means considering how SSO rules affect IP incentives im different industries. My conclusion is a qualifiedly optimistic one. SSOs are a species of private ordering that may help solve one of the fundamental dilemmas of IP law: the fact that IP rights seem to promote innovation im some industries but harm innovation in others. SSOs may serve to ameliorate the problems of overlapping IP rights in those industries in which $I P$ is most problematic for innovation, particularly in the semiconductor, software, and telecommumcations fields. But this process of private ordermg isn't perfect, and there isn't a very good "market" for IP rules driving them towards efficiency. This leaves a dual role for the governinent: on the one hand, to enforce these private-ordering agreements and avoid unduly restricting SSOs by overzealous antitrust scrutiny; but on the other hand to scrutinize the standard-setting process to ensure that SSO IP rules do in fact work as they are intended. 


\section{The NATURE AND Importance of STANDARd-SeTting ORganizations}

\section{A. The Value of Standardization}

Standards (and SSOs) come in a variety of forms. ${ }^{13}$ I define a standard rather broadly as any set of technical specifications that either provides or is intended to provide a common design for a product or process. Some standards are extremely complex and technical in nature. For example, the set of application-programming interfaces that defines compatibility with the Microsoft Windows operating system is an industry standard; those who know and use the proper interfaces are compliant with the standard, and their products will "interoperate" with the Microsoft operating system. But standards need not be so sophisticated. Ordinary consumers use a wide variety of standardized products in everyday life. In the United States, electrical plugs and outlets are built to a particular standard for voltage, impedance, and plug shape. Without this standardization, no one could stay in a hotel room and have any confidence that his hair dryer would work in the hotel's outlet. The modern economy has countless standardized products, including, just to name a few, telephone service, computer-modem communication protocols, and automobile ignition and transmission systems.

As these examples attest, standardization has significant consumer benefits in many markets. ${ }^{14}$ This is especially true in so-called "network markets," where the value of a product to a particular consumer is a function of how many other consumers use the same (or a compatible) product. ${ }^{15}$ The paradigmatic example is the telephone network, in which the value of the product is driven entirely by the number of other people on the same network. Still other products, like computer operating systems, have some intrinsic value regardless of how many people use them, but gain value as more and more consumers adopt them. In these industries, consumers benefit from standardization not only because they can reliably use their products in remote locations, but also because they can exchange information with others who use the same standard. Further, in markets for complementary products, companies will often gear their production to work with a product that is an industry standard, rather than a product that

13. Indeed, Peggy Radin has argued that standards are not just technical, but legal, and that the two types are converging. Margaret Jane Radin, Online Standardization and the Integration of Text and Machine, 70 FoRdHAM L. REv. 1125 (2002).

14. On the value of standardization, see Gifford, supra note 11, at 11-12.

15. For literature on network effects, see, for example, Joseph Farrell \& Garth Saloner, Standardization, Compatibility, and Innovation, 16 RaND J. Econ. 70 (1985); Michael Katz \& Carl Shapiro, Network Externalities, Competition, and Compatibility, 75 AM. ECoN. REv. 424 (1985); Mark A. Lemley \& David McGowan, Legal Implications of Network Economic Effects, 86 CALIF. L. REV. 479 (1998) [hereinafter Lemley \& McGowan, Networks]; S.J. Liebowitz \& Stephen E. Margolis, Network Externality: An Uncommon Tragedy, 8 J. ECON. PERSP. 133 (1994). 
has only a small market share. For example, software vendors are more likely to write application programs that are compatible with Microsoft's operating system than with other operating systems, because there are more consumers for such a product. This in turn reinforces the desire of consumers to buy the product everyone else buys-a phenomenon known as "tipping." I6 In network markets, then, standardization may well be inevitable, and certainly carries substantial consumer benefits.

Even in non-network markets, standard setting can have a variety of procompetitive and other beneficial effects. For example, standards can facilitate competitive markets for replacement parts or service in durablegoods industries. Further, in many industries, standards may be valuable for reasons unrelated to or even inimical to competition. Construction products must meet industry standards for fire resistance, and doctors, lawyers, and many other professionals must meet minimum licensing standards. These latter standards aren't procompetitive im the narrow sense of encouraging price competition; indeed, they may have the opposite effect. But standards of this type can still promote social welfare by ensuring that imperfect information does not lead consumers to buy dangerous products or hire unqualified doctors simply because they cost less. ${ }^{17}$

While standardization can be beneficial in a wide variety of markets, it is worth distinguishing between two different types of standards: standards that control imteroperability in a network market and those that govern the quality or safety of a product. In the former group, which I will call "network," "compatibility," or "interface" standards, the intrinsic value of the standard selected is only part of the social benefit of standard setting. Simply agreeing on a standard for two products to interact has value in a network market, whether the interface actually chosen is the best one or not. Indeed, in some cases it may be more important that an industry coalesces around a single standard than which particular standard is chosen. ${ }^{18}$ By contrast, standard setting outside of network markets tends to be concerned primarily with the intrinsic value of the product itself, and

16. See Michael L. Katz \& Carl Shapiro, Systems Competition and Network Effects, 8 J. EcoN. PeRSP. 93, 105-06 (1994).

17. Whether a consumer-protection justification renders an otherwise anticompetitive agreement legal is a matter of some debate. On the one hand, the Supreme Court seemed to rule out any antitrust defense based along these lines in National Soc'y of Professional Engineers v. United States, 435 U.S. 679,696 (1978) ("[T] competition itself is unreasonable."). On the other hand, many lower courts have recognized such a defense, holding at least that it precludes per se illegality. See, e.g., Kreuzer v. Am. Acad. of Periodontology, 735 F.2d 1479, 1493-94 (D.C. Cir. 1984) (holding that a rule that restricted organizational membership to those who exclusively practiced a stated dental specialty was subject to rule-of-reason analysis); Wilk v. Am. Med. Ass'n, 719 F.2d 207, 221 (7th Cir. 1982) (holding that "patient care" defense raised by organization required rule-of-reason treatment). Because this debate does not directly conceru IP cases, its resolution is outside the scope of this Article.

18. For example, there is no intrinsic value in driving on either the left or the right side of the road, but it is critically important that everyone in a particular region pick the same side. 
only secondarily with the network benefits of agreement on a particular standard. These latter standards may guarantee minimum licensing qualifications for the professions or specify safety codes that consumer products must meet. ${ }^{19}$

In this Article, I am primarily concerned with compatibility standards. Those standards are more likely than safety standards to be exclusive. There are many different medical practices or electrical conduits that may be acceptable, but generally there aren't many different protocols that will connect one to the Internet. Thus, for those safety standards that are covered by IP rights, it is easier to "design around" the IP rights by adopting a permitted alternative than it is in a non-network market. As a result, IP rights tend to be less important with respect to safety standards than compatibility standards. ${ }^{20}$

\section{B. Organizational Forms of Standardization}

Standardization may take a variety of organizational forms..$^{21}$ One approach to achieving interoperable standards is for a private industry organization open to all companies to adopt a single standard. If the members of such a group collectively have a significant market share, their adoption of a standard may produce the "tipping" effect described above, bringing the rest of the industry into line. ${ }^{22}$

19. Or they may do stranger things. See Jessup v. Am. Kennel Club, 61 F. Supp. 2d 5 (S.D.N.Y. 1999), aff'd per curiam 210 F.3d 111 (2d Cir. 2000), cert. denied, 531 U.S. 1072 (2001) (involving an antitrust challenge to an American Kennel Club standard that set a minimum-height requirement for show dogs).

20. This isn't to say that safety SSOs never have IP rules or that enforcement of those rules does not present interesting issues. See, e.g., In re Am. Soc'y of Sanitary Eng'g, 106 F.T.C. 324, 329 (1985) (holding that an SSO could not reject standards solely on the basis that they were patented). Janice Mueller goes so far as to suggest that patents are neeessary for interface standards but not for products that comply with health and safety standards. Mueller, Misuse, supra note 8, at 651-53. But Mueller seems to be thinking of patents that cover a health and safety standard set by the government that mandates the use of a single product. The case on which she foeuses, involving Unoeal's assertion of a patent covering reformulated gasoline mandated by the California Air Resources Board, fits that model. Union Oil Co. of Cal. v. Atl. Richfield Co., 208 F.3d 989 (Fed. Cir. 2000), cert. denied, 531 U.S. 1183 (2001). But that is a rare situation indeed. For a discussion of the facts of the Unocal case, see Scott $\mathrm{H}$. Segal, Fuel For Thought: Clean Gasoline and Dirty Patents, 51 Am. U. L. Rev. 49 (2001).

In any event, most of the disputes concerning SSO IP rules arise in the telecommunications, computer, and semiconductor markets. See infra note 263.

21. On the choice between formal and de facto standardization, see Joseph Farrell \& Garth Saloner, Coordination Through Committees and Markcts, 19 RAND J. Econ. 235 (1988).

22. See supra note 16 and accompanying text. SSOs have the potential to harness network effects while permitting competition within a single standard. See MARTIN LIBICKI ET AL., SCAFFolding THE New Web: Standards and Standards Policy for the Digital Economy (2000); Lemley \& McGowan, Networks, supra note 15, at 516; Marcus Maher, An Analysis of Internet Standardization, 3 VA. J.L. \& TECH. 5, 999 27-30 (1998). Of course, not all SSOs havc such market control. As Libicki observes, many of the most successful SSO standards started small and grew to become dominant. See Martin C. Libicki, Standards: The Rough Road to the Common Byte, in STANDards Policy For INFORMATION INFRASTRUCTURE 35, 75 (Brian Kahin \& Janet Abbate eds., 1995); see also Jim Isaak, Information Infrastructure Meta-Architecture and Cross-Industry Standardization, in STANDARDS 
Not all standards are created by private SSOs, however. Two other organizational forms are worth considering. First, a standard may arise from the operation of the market, as consumers gravitate towards a single product or protocol and reject its competitors. ${ }^{23}$ This form of "de facto" standardization is particularly likely in markets characterized by strong network effects, because of the large benefits associated with adopting the same product everyone else does. To take just one example, the Microsoft operating systeins are clearly de facto standards; no SSO "adopted" them as the preferred or official operating systems, but the inarket chose Microsoft as the winner of a standards competition.

The other possibility is that the government might identify and set the appropriate standards and coinpel all participants in the market to comply. The government does this from time to time. For example, the Federal Communications Commission ("FCC") sets standards for interconnection between telephone networks and standards governing the use of products that might interfere with broadcast communications. ${ }^{24}$ In the 1990 s, the U.S. government stepped into the debate over the proper standard for high definition television ("HDTV"), selecting a standard that unified U.S. HDTV development but was at odds with standards adopted in Japan and Europe..$^{25}$ Similarly, government agencies such as the Advanced Research Projects Agency and the National Science Foundation played a crucial role in the development of the Internet, including the creation of Internet interconnection protocols. ${ }^{26}$ Indeed, some private Internet SSOs such as InterNIC and the IETF were once government-sponsored organizations. ${ }^{27}$

In this Article I shall primarily be concerned with the activities of private SSOs. While de facto standards do raise significant antitrust issues relating to IP, they are analytically distinct from the ones I discuss here. ${ }^{28}$

POLICY For INFORMation INFRAstructure 100, 101 (Brian Kahin \& Janet Abbate eds., 1995) (arguing that group or open standards "must also reach the status of being 'de facto' to be sufficient").

23. On de facto standards as an alternative to group standards, see Lemley, Internet Standardization, supra note 11, at 1060-65; Maureen A. O'Rourke, Striking a Delicate Balance: Intellectual Property, Antitrust, Contract, and Standardization in the Computer Industry, 12 HARV. J.L. \& TECH. 1, 5 (1998).

24. See 47 C.F.R. $\$ 68.1(2000)$.

25. See Denise Caruso, Debate Over Advanced TV Gives the F.C.C. a Chance to Be Assertive, N.Y. TmEs, June 17, 1996, at D5; F.C.C. Proposes Standards for Digital Television, N.Y. Times, May 10,1996 , at $\mathrm{D} 4$.

26. See, e.g., Jay P. Kesan \& Rajiv C. Shah, Fool Us Once Shame on You-Fool Us Twice Shame on Us: What We Can Learn from the Privatizations of the Internet Backbone Network and the Domain Name System, 79 WASH. U. L.Q. 89 (2001).

27. Id.

28. For a discussion of the antitrust and IP issues raised by de facto standards, see Joseph Farrell \& Michael L. Katz, The Effects of Antitrust and Intellectual Property Law on Compatibility and Innovation, 43 ANTITrust Bull. 609 (1998); Lemley, Internet Standardization, supra note 11, at 1060-62; John E. Lopatka \& William H. Page, Microsoft, Monopolization, and Network Externalities: Some Uses and Abuses of Economic Theory in Antitrust Decision Making, 40 
Generally speaking, a de facto standard will be proprietary unless the standard setter chooses to release it to the public. Government-set standards also present a very different set of issues, in part because of the stateaction and petitioning-immunity doctrines. ${ }^{29}$ Government standard setting is also on the wane, as more and more responsibility for standardization devolves upon the private sector. ${ }^{30}$

While standardization has great economic value in many markets, group standard setting also poses some potential threats to competition. Absent network effects, economists generally presume that consumers fare best when many companies compete to offer different sorts of products. To the extent that standardization on a single product reduces consumer choice, it may be undesirable. ${ }^{31}$ Of course, if a market is truly competitive, unnecessary standardization eventually should disappear in the face of competition presented by different sorts of products offered by new entrants. But SSOs may be able to impede such competition, in effect acting as a cartel with the power to reduce output by excluding certain kinds of products. ${ }^{32}$ Thus, courts must balance the procompetitive virtues of SSOs against the risks that they will facilitate collusion. ${ }^{33}$ The general nature of this problem is discussed in more detail below. ${ }^{34}$ But it would be a mistake to generalize from the competitive risks of group standard setting to a conclusion that SSOs themselves normally ought to be suspect. Rather, courts should give some deference to the legitimate aim of standardizing

ANTITRUST Bull. 317 (1995); David McGowan, Networks and Intention in Antitrust and Intellectual Property, 24 J. CoRP. L. 485 (1999); O'Rourke, supra note 23.

29. For more detail on these doctrines, see 1 Philip E. Areeda \& Herbert HovenKamp, ANTITRUST LAW ๆf 200-231 (2d ed. 2000).

30. See, e.g., Christopher T. Marsden, Cyberlaw and International Political Economy: Towards Regulation of the Global Information Society, 2001 L. REv. Mich. ST. U. DET. C.L. 355, 358-59 (2001) [hereinafter Marsden, Cyberlaw]. For a detailed discussion of government standard setting in the Internet environment, see Christopher T. Marsden, The Challenges of Standardization-Towards the Next Generation Internet, in lNTERNET TV (Eli Noam et al., eds.) (forthcoming 2002); Kesan \& Shah, supra note 26.

31. See 13 Herbert HovenKamp, ANTITrust Law q 2136 (1999) (standardization can reduce competition by eliminating desirable product differentiation).

32. See Anton \& Yao, supra note 11, at 249-51; Thomas A. Piraino, Jr., A Proposed Antitrust Approach to Collaborations Among Competitors, 86 lowA L. REv. 1137, 1204 (2001); Elbert L. Robertson, A Corrective Justice Theory of Antitrust Regulation, 49 CATH. U. L. Rev. 741, 760-63 (2000). Sometimes an SSO wields economic power because it consists of the largest companies in the industry. But some SSOs may wield direct legal control over a market, either directly (as where the courts delegate to bar associations the power to control entry into the profession) or indirectly (as where a private SSO adopts standards that are routinely enacted into law by legislatures or city councils).

For an argument that the risk of price coordination has increased as the internet makes it easier for competitors to discover each othcr's product and price information, see Jonathan B. Baker, Identifying Horizontal Price Fixing in the Electronic Marketplacc, 65 ANTITRUST L.J. 41 (1996).

33. Cf. Robert Pitofsky, Antitrust and Intellectual Property: Unresolved Issues at the Heart of the New Economy, 16 BERKeley TECH. L.J. 535, 550 (2001) (arguing that SSOs can facilitate innovation, but are also subject to abuse).

34. See infra Part 1V. For more detail, see 13 Hovenkamp, supra note 31, q 2231 b; 2 HerberT HovenKamp ET AL., IP AND ANTITRUST ch. 35 (2002). 
products, particularly in network markets. ${ }^{35}$ And they should acknowledge that group standard setting may be more desirable than de facto standardization because it allows for competition in making products that comply with the standard.

\section{The Relationship of Standardization to Intellectual Property}

Briefly stated, the issues analyzed in this Article arise when an SSO adopts (or fails to adopt) a standard that is covered in whole or in part by an IP right-generally but not necessarily an IP right owned by a party that has some dealings with the SSO ${ }^{36}$ Prior work by Joe Farrell found that IP rights create divergent vested interests among participants in SSOs, and therefore delay formal standard setting and make consensus less likely. ${ }^{37}$ To combat these effects, SSOs frequently use formal or informal mechanisms, such as rules governing the ownership of IP or joint defense arrangements, to lessen an IP owner's control over a standard they adopt. These arrangements may themselves be challenged as anticompetitive, but they may also be necessary to ensure that competition in a network market isn't disrupted by IP owners.

These arrangements are the subject of this Article. They are a form of private ordering that enables market participants to collectively "contract around" initial entitlements of IP rights. To evaluate the effect of this form of private ordering, I flrst discuss the results of my empirical mvestigation into how these rules actually work. I then discuss the legal implications of SSO IP rules-both their enforceability under contract and IP law and their antitrust consequences. I next try to fit SSO IP rules into a larger theoretical context, examining both the "messy" nature of private ordering by SSOs and how SSO IP rules may help solve significant holdup problems in IP law.

Whether and how an SSO regulates IP rights will determine whether the standards it sets are "open" or "closed." Group standards set by SSOs that do not restrict IP rights at all are likely to be closed. Because one or more members of the SSO likely owns a patent covering the standard, that

35. For a more detailed argument along these lines, see Lemley, Internet Standardization, supra note 11, at 1079-86; Phil Weiser, Networks Unplugged: Towards a Model of Compatibility Regulation Between Information Platforms 12 (2001) (draft working paper, on file with author) [hereinafter Weiser, Networks Unplugged]. A recent Supreme Court deeision suggests that the law is moving in this direction. See Cal. Dental Ass'n. v. FTC, 526 U.S. 756, 759-65 (I999) (finding "quick look" rule of reason inappropriate when applied to the rules of an SSO).

36. If an SSO adopts as a standard a technical desigu covered by a patent owned by a nonmember, only a more limited set of antitrust issues arise. The IP owner is entitled to enforce its patent against those who use the standard. By contrast, refusal to adopt a standard covered by a patent owned by a third party could present antitrust issues, which I discuss infra Part IV.C.2.

37. See, e.g., Joseph Farrell, Standardization and Intellectual Property, 30 JuRIMETRIcs J. 35, 44 (1989); Joseph Farrell, Choosing the Rules for Formal Standardization 15-16 (Jan. 14, 1996) (draft working paper, on file with author) [hereinafter Farrell, Choosing]. 
company will effectively control the standard; its patent gives it the right to enjoin anyone else from using the standard. ${ }^{38}$ Because many SSOs want the public to be free to use their standard, they will often require members to give up any IP protection that covers the standard. The resulting standard is open-anyone is free to use it. ${ }^{39}$ There is a voluminous literature on the relative value of open and closed standards, especially in network industries, and a vociferous debate over the merits of both approaches. ${ }^{40}$

In the next Part, I study a number of SSO IP policies and find both open and closed groups. Importantly, however, most SSOs that I study fall into neither category. ${ }^{41}$ Rather, these SSOs occupy a middle ground between open and closed standards. They permit their meinbers to own IP rights, but require those meinbers to commit in advance to licensing those rights on specified terms and to forgo injunctive relief altogether. These standards are open in the sense that no one can be prohibited from using them. ${ }^{42}$ But they are also proprietary; those who would use the standard must pay royalties to the IP owner. This intermediate approach is a way of valuing IP while at the same time reducing the risk that IP rights will

38. See 35 U.S.C. $\S 283$ (2000) (authorizing injunctive relief). Patents are protected by a "property rule" regime in which an injunction is the expected remedy. See ROBERT P. MERGES ET AL., Intellectual Property in the New Technological Age 321-23 (2d ed. 2000).

39. Technically, the standard is open only in the sense that members of the SSO have waived any claims of $1 \mathrm{P}$ ownership. There is no way to prevent nonmembers from later asserting $1 \mathrm{P}$ rights.

40. See Dennis W. Carlton \& Robert H. Gertner, Intellectual Property, Antitrust aND Strategic Behavior (Nat'l Bureau of Econ. Research, Working Paper No. 8976, 2002); David Friedman, Standards as Intellectual Property: An Economic Approach, 19 U. DAYTON L. REv. 1109, 1122 (1994); Mark A. Lemley, Standardizing Government Standard-Setting Policy for Electronic Commerce, 14 BerKeley TECH. L.J. 745, 751-52 (1999); Mark A. Lemley \& David McGowan, Could Java Change Everything? The Competitive Propriety of a Proprietary Standard, 43 ANTITRUST BulL. 715 (1998); Marsden, Cyberlaw, supra note 30, at 382-83; David McGowan, The Problems of the Third Way: A Java Case Study, in Regulating the Global INFormation Societr 243 (Christopher Marsden ed. 2000); Mueller, Patenting Industry Standards, supra note 11; Mueller, Misuse, supra note 8, at 650-51; Schallop, supra note 11, at 195; Molly van Houweling, Cultivating Open Information Platforms: A Land Trust Model, 1 J. Telecom. \& High TECH. L. (forthcoming 2002); Weiser, Internet Governance, supra note 11, at 825-32; Philip J. Weiser, Law and Information Platforms, $1 \mathrm{~J}$. TELECOM. \& HiGH TECH. L. (forthcoming 2002) [hereinafter Wciser, Information Platforms]; Philip J. Weiser, The Internet, Innovation, and Intellectual Property Policy 13 n.46 (2002) (draft working paper, on file with author); UPDEGROVE, supra note 11.

The relative value of open and closed standards in what Phil Weiser calls "information platforms" may differ depending on the layer of technology the standard would cover. There is a reasonable argument for open platforms at the lower or infrastructure layers even if the higher software and content layers are proprietary. For a discussion of the layered model of the Internet, see Kevin Werbach, A Layered Model for Internet Policy (2000) (draft working paper, on file with author). $C f$. Mark A. Lemley \& Lawrence Lessig, The End of End-to-End: Preserving the Architecture of the Internet in the Broadband Era, 48 UCLA L. REv. 925, 939-40 (2001) (discussing the related but distinct question of whether technology should be located in the higher or lower layers).

41. See infra notes 57-62 and accompanying text.

42. Virtually all of these intermediate approaches require that licenses be granted on nondiscriminatory terms, preventing an IP owner from closing the standard to particular competitors. 
impede standardization and hold up innovation. ${ }^{43}$ It therefore offers a "third way" of handling the allocation of rights in standards. ${ }^{44}$

II

\section{How STANDARD-SeTting ORganizations Treat INTELlectuaL PROPERTY RighTS}

\section{A. Organizations Studied}

To see how SSOs treat IP rights, I surveyed the rules and bylaws of forty-three different SSOs. The SSOs I chose were ones to which companies in the telecommunications and computer-networking industries, where many of the most contentious IP issues arise, were likely to belong. They included both large national or international SSOs that set standards in a variety of industries, smaller SSOs centered within particular industries, and consortia that formed around specific standards. The collection of SSOs here is by no means comprehensive, even within the telecommunications and computer-networking industries. ${ }^{45}$

I sought to identify several pieces of information with respect to an SSO's policy on IP rights. I first asked whether the SSO had any policy at all regarding IP. If they did, I then sought to determine whether the policy covered only patents, or whether it covered other forms of IP rights as well. I also sought to categorize the policy according to three factors. First, I determined whether it required disclosure of an IP right (I also made certain subsidiary determinations, such as the nature of the obligation, if any, to search a firm's own inventory for relevant patents, and whether disclosure extended to pending as well as issued patents). Second, I determined the effect of an IP disclosure on the standard-setting process under the policy: chiefly, whether the SSO would refuse to adopt a standard covered by a patent or whether it would apply different procedural rules to the process of adopting such a standard. Finally, I determined whether the SSO imposed a licensing requirement on IP owners and, if so, the nature of that requirement.

43. See Shapiro, Thicket, supra note 11.

44. Cf. Weiser, Internet Governance, supra note 11, at 826-32 (discussing possible means of allocating rights, and noting an intermediate position between open and proprietary approaches).

45. The particular SSOs I chose were in one or both of the following groups: (1) ones of which Sun Microsystems was a member in the late 1990s and which were still in existence as of January 2001. Some of the SSOs 1 studied permit only governments to be members; 1 nonetheless included them if Sun participated as an observer; (2) groups listed at http://www.consortiuminfo.org/ ssl/links.php?cat $=1$ that fit into the telecommunications or computer networking categories. The policies were checked and updated in June 2002. Consortiuminfo.org, Consortium and Standards List, at http://www.consortiuminfo.org/ssl/links.php?cat=1. 1 have consolidated multiple working SSOs operating under the aegis of the same SSO and subject to the same policy. 


\section{B. Results $^{46}$}

What is most striking about the data is the significant variation in policies among the different SSOs. Of the forty-three SSOs I studied, thirty-six had written policies governing the ownership of IP rights, four had no policy at all, ${ }^{47}$ two had statements on their website about IP rights but no official policy, and one had a policy that was still in development. ${ }^{48}$ Most SSOs without any policy were small, industry-specific groups; all of the large SSOs I studied had well-developed policies in this area. Further, from 1999 to 2002 more organizations developed policies, reflecting the increased salience of the issue. ${ }^{49}$ These rules tended to be set in the bylaws of the SSOs, although the organizational diversity of SSOs meant that arrangements in any given case may have been more or less formal. ${ }^{50}$

The requirements imposed by the policies varied significantly from SSO to SSO. The majority of SSOs that had a policy (twenty-four of thirtysix) imposed either an express or implied obligation that members disclose IP rights of which they are aware. Those SSOs that did not require disclosure generally imposed other conditions that obviated the need for disclosure. For example, some SSOs required royalty-free licensing of all member IP rights that cover a group standard, whether or not they were disclosed to the SSO. ${ }^{51}$

There was greater variation, however, with respect to what must be disclosed. While virtually all the policies I studied covered patents, a smaller (but still significant) number also covered copyright and trademark rights, or referred globally to "intellectual property rights" subject to the policy. ${ }^{52}$ Where patents are concerned, most SSOs considered only issued patents. There was rarely discussion of the problem of pending patent applications. ${ }^{53} \mathrm{~A}$ few SSOs considered the issue, but did not require the

46. The full data from this survey are printed in the Appendix, infra.

47. At least, no policy that either I or my research assistant could find. Some SSOs may make their policy available only to members.

48. The policies were collected in mid-1999 and reviewed in early 2001 , then reviewed again in mid-2002. Except where noted the discussion in the text refers to the policies as they existed in June 2002.

49. In 1999 , only twenty-one of twenty-nine organizations I studied (or $72 \%$ ) had policies; by 2002 , thirty-eight of forty-three ( $88 \%$ ) had either a policy or some official statement on IP rights.

50. With respect to mandatory disclosure policies, for example, some policies are merely statcd in bylaws, while others require members to affirmatively sign a statement indicating that they do not own IP rights in a particular proposed standard.

51. This was the policy of 120 SIG and Wired for Management. Similarly, RosettaNet required assignment of IP rights to the SSO itself, and the British Standards Institute relied on a provision of British patent law that gave licenses to members as of right. Only one SSO, the Distributed Management Task Force, had a policy that neither required disclosure nor included some automatic provision for $\mathrm{IP}$ owners giving up or licensing their rights.

52. Thirteen of the thirty-six SSOs with policies applied the policy only to patents. Many other organizations applied different rules to patents and copyrights.

53. As we will see, this is a significant problem. See infra notes 154-60 and accompanying text. 
disclosure of pending applications, which are ordinarily kept confidential. Four SSOs (the ITU, the ECMA, the Joint Electronics Devices Engineering Council's ("JEDEC"), and OSGi) required disclosure of all pending patent applications. Two other SSOs had an intermediate policy: the ATM Forum required disclosure of published patent applications, but not unpublished ones, ${ }^{54}$ while the Open Mobile Alliance required disclosure even of unpublished patent applications, but only from a member who was also the proponent of a standard.

Curiously, very few of the SSO rules I studied required a member to search either its own files or the broader literature to identify relevant IP rights. Only four SSOs (NIST, the European Telecommunications Standards Institute ("ETSI"), the Open Group, and the Frame Relay Forum) required such a search, and ETSI's requirement was subject to waiver; it provided that either ETSI or the member would be required to conduct a search..$^{55}$ Only the Frame Relay Forum specified the sort of search that must be conducted, and even that was done in broad terms (a "reasonable" search). As I discuss below, the failure of SSOs to require searches, while understandable given the time and resource constraints under which members operate, gives rise to serious problems. ${ }^{56}$

Most SSOs permitted members to own IP rights in a standard, although they often discouraged it. Only two SSOs appeared to flatly prohibit ownership of IP rights by a private party. ${ }^{57}$ In addition, four SSOs studied (I2O SIG, RosettaNet, MWIF, and Wired for Management) permitted a mcmber to own patents, but only if they agreed to license the patents to other members on a royalty-free basis. Royalty-free licensing allows IP rights to retain some value, since they can be asserted against products that do not embody the standard, but it is essentially worthless against other members of the SSO. ${ }^{58}$ ISO required members to give up patent rights, though not other sorts of IP rights. ${ }^{59}$ Other SSOs discouraged ownership of IP without actually forbidding it. ETSI would reconsider its decision to approve a standard if the standard turned out to be controlled by an IP

54. In most of the world, patent applications are published eighteen months after filing. In the United States, patent applications until recently were kept secret unless and until a patent issued. However, since 1999, most U.S. patent applications are published eighteen months after filing, although some applicants can maintain their application as a secret beyond that point. See 35 U.S.C. $\S 122$ (2000). Even before 1999, many U.S. patent applications were publishcd because the applicants also filed abroad.

55. One other group (the ECMA) provided that "members will determine" what IP rights apply to the standard, which might be thought to compel members to identify and disclose their IP rights.

56. See infra notes 297-300 and accompanying text.

57. $O M G$ and $D I N$.

58. Whether such an IP right could be asserted against nonmembers using the standard is an open question.

59. Another ten SSOs had different rules for patents and copyrights, permitting reasonable and nondiscriminatory licensing for patcnts but requiring assignment or royalty-free licensing of copyrights. This is the inverse of ISO's rule. 
right. The ATM Forum required a three-fourths majority to approve a standard governed by an IP right, and similarly made it easier to revoke a standard if it was found to be covered by an IP right. Several SSOs expressly discouraged the ownership of IP in standards, but would permit them in exceptional cases. ${ }^{60}$ And at least one SSO (the Open Mobile Alliance) appeared to take inconsistent positions on the ownership of IP. ${ }^{61}$

Even those SSOs that permitted members to own IP rights that cover a standard generally imposed some conditions on the use of that IP. The most common condition was that IP rights be licensed on "reasonable and nondiscriminatory terms"; twenty-nine of the thirty-six SSOs with policies required members to license their patent rights on such terms. As noted above, another six SSOs required assignment or royalty-free licensing. Three SSOs had a looser standard, requesting that members agree to license their patents on reasonable and nondiscriminatory terms, but not requiring that they do so.

While "reasonable and nondiscriminatory licensing" thus appears to be the majority rule among SSOs with a patent policy, relatively few SSOs gave much explanation of what those terms mean or how licensing disputes would be resolved. Only two SSOs specifically provided that the licensing obligation compels a member to license to everyone in the world using the standard, not just to license to other members. It does not necessarily follow that the remaining SSOs intended to restrict the licensing obligation; ${ }^{62}$ rather, it appears that they simply had not addressed the issue in their policies. Four SSOs either gave content to the obligation by specifying what a "reasonable" term means, or provided a mechanism for the SSO to resolve disputes about license terms and fees. And one SSO required not only that a license term be reasonable and nondiscriminatory, but also that it not constitute "monopolistic abuse" of a patent. In short, while IP owners at many SSOs were required to license their rights on reasonable and nondiscriminatory terms, it isn't clear what those obligations mean in practice.

\section{Implications of Diversity}

The fact that different SSOs have different mles governing IP rights (or no rules at all) means that it is very difficult for IP owners to know ex

60. See Comité Europeén de Normalisation, CEN/CENELEC Guide No. 8, Standardization and Intellectual Property Rights $\S 1$ (1992), available at http://www.cenorm.be?BOSS?supmat/refdoc/ mm008.htm (allowing ownership of standards "in exceptional cases" only); Am. Nat'l Standards lnst., Guidelines for Implementation of the ANSI Patent Policy, at http://www.ansi.org/public/ library/guides/ppguide.html (1998) (permitting patented standards only if "technical reasons justify this approach"); Internet Eng'g Task Force, Home Page, at http://www.ietf.org/ (last visited Sept. 13, 2002) (stating that it "prefers" unpatented technology).

61. See supra text accompanying note 54 .

62. Such a restriction would pose serious antitrust concerns. See 2 HovenKAMP ET AL., supra note $34, \S 35.3$. One group (the Parlay Group) did restrict reasonable and nondiscriminatory licensing to members only. 
ante what rules will govern their rights. Because there is no standard set of rules, companies must investigate the bylaws of each SSO they join in order to understand the implications of joining. While this doesn't seem too onerous a burden in the abstract, a number of practical considerations indicate that companies are unlikely to be fully informed about their IP position.

First, most companies in technology industries participate in more than one SSO. To take just one exainple, in 1998 Sun Microsysteins participated in eighty-seven different SSOs. For purposes of this study, I have consolidated those SSOs, eliminating those that are subsets of another SSO and rely on the parent SSO's IP policy. For example, many of the SSOs Sun belonged to operated under the umbrella of IEEE or ANSI. I have also elininated those SSOs that were no longer in existence as of January 2001. Even after such consolidation, the list is impressive. ${ }^{63}$ Similarly, there are dozens of different SSOs associated with Internet technical standards alone. ${ }^{64}$

Thus, technology companies don't inerely have to figure out what rules apply to them, but they also face a labyrinth of different SSOs with overlapping subject natter concerns, each with its own set of rules. Because SSOs are concerned only with IP rights that affect their particular standards, the likely result will be that sonie of a company's IP rights will be subject to effective forfeiture, more will be subject to disclosure and licensing requirements, and sonie will not be restricted. Lawyers would have to examine each SSO, each standard, and each patent carefully to know for sure which rule applies.

This brings us to a second practical problen1. Lawyers rarely participate im standard-setting ineetings. A company's representative to such an SSO is normally an engineer with little or no understanding of patent law. Indeed, in many cases my sense is that the decision whether or not to join an SSO is made at a fairly low level within a company, without the involvement of senior businesspeople, much less lawyers. If the SSO in question is one of the few that compels assignment or royalty-free licensing, or requires a search for IP, the decision to join may inadvertently commit the coinpany to give up inajor IP rights.

Because of these practical limitations, inost technology companies today face a hodgepodge of rules and obligations of which they are only dimly aware. In the remaining Parts, I explore some of the legal rules that bear on SSOs, identify some of the problems that arise in articulating and enforcing IP policies, and offer some suggestions to all the players involved-members, SSOs, courts, and scholars-for how to think about the IP rules of SSOs.

63. See Figure 1.

64. See ConsortiumInfo.org, supra note 45. 
Figure 1. Standard-Setting Organization List by Function

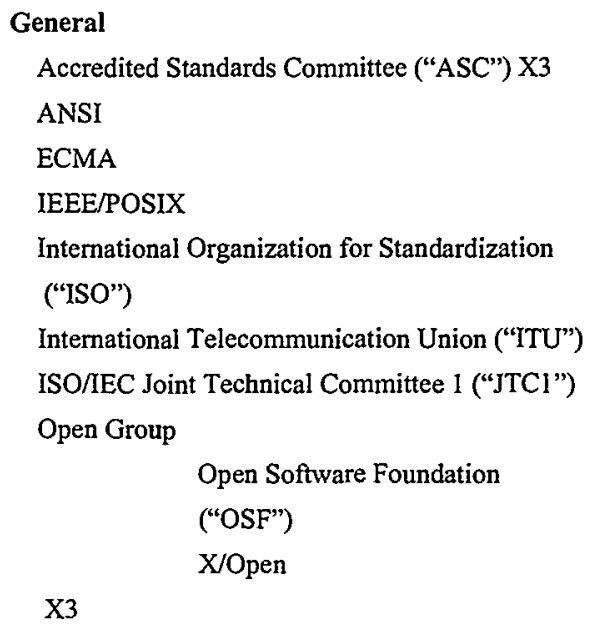

\section{Communications and Networking}

Asynchronous Transfer Mode ("ATM") Forum CommerceNet

Financial Services Technology Consortium ("FSTC")

Frame Relay Forum ("FRF")

Internet Society

Internet Engineering Tax Force ("IETF") Internet RFCs

\section{Communications and Networking, Cont.}

Information Infrastructure Standards Panel ("IISP")

Network Management Forum ("NMF")

World Wide Web Consortium ("W3C")

\section{Desktop and Graphics}

Component Integration Laboratories ("CIL")

Desktop Management Task Force ('DMTF”)

International Color Consortium ("ICC")

Interactive Multimedia Association ("IMA")

Moving Pictures Experts Group ("MPEG")

Multimedia and Hypermedia Information Coding

Experts Group ("MHEG")

Open GL

$\mathrm{X}$ Consortium

\section{US Government and Other Nations}

Asia Oceanic Workshop ("AOW")

Chinese Open Systems Association ("COSA")

Defense Information Systems Agency ("DISA")

DoD Specifications and Standards

European Commission DGXIII/E Open

Information Interchange ("OII") Initiative

European Workshop for Open Systems ("EWOS")

Federal Information Processing Standards ("FIPS")

Japanese Industrial Standards Committee ("IISC")

National Institute of Standards \& Technology

("NIST")

Open Systems Environment Implementors

$$
\text { Workshop ("OIW") }
$$




\section{III \\ The ENFORCEABILITY OF STANDARD-SETTING ORganization RULES RESTRICTING INTELLECTUAL PROPERTY}

In order to understand the full import of SSO IP rules, we must consider whether and to what extent those rules are binding on members of an SSO. Whether SSO IP rules constitute private ordering in the shadow of IP law depends on how the law treats those rules. Unfortunately, there is virtually no case law on this subject. But even a cursory review of the contract and patent law issues such rules raise suggests that the problem is a complicated one. In this Part, I evaluate the legal rules, concluding that contract and IP law should be interpreted to enforce SSO IP rules, but that existing doctrine poses some obstacles to effective enforcement.

\section{A. Standard-Setting Organization Intellectual Property Rules as Creatures of Contract Law}

\section{Are Bylaws Binding Contracts?}

SSO IP rules have legal significance only to the extent they are enforceable. ${ }^{65}$ Because the IP policies are at base agreements by members of the SSO to abide by certain rules regarding IP ownership, their enforceability is initially a question of contract law.

At the outset, it is worth emphasizing that an SSO bylaw at most can bind those companies that are members of the SSO. Nonmembers aren't party to the contract, and will not be held to have agreed to the bylaws. ${ }^{66}$

65. They may have some effect as nonbinding norms as well. I do not consider those effects in this Article.

66. One possible exception to this limitation might take the form of a "viral" approach to standard setting. An SSO may seek to impose its rules not just on members, but on anyone who uses the standard. It might do this either by purporting to create a contract accepted by performance-the act of using the standard-or by copyrighting the specifications of the standard and conditioning a license to the copyright on agreement to comply with the IP rules. Such a viral approach, binding anyone who comes into contact with the standard, has parallels in both the "shrinkwrap license" cases and in open source contracting. Peggy Radin has referred to shrinkwrap licenses as "covenants that run with" software, because even those who aren't part of any express agreement are purportedly bound by a contract that is attached to the program itself, and which provides that using the software constitutes agreement to its terms. Margaret Jane Radin \& $\mathrm{R}$. Polk Wagner, The Myth of Private Ordering: Rediscovering Legal Realism in Cyberspace, 73 CHI.-KeNT L. REv. 1295, 1312 (1998). On the viral-contract nature of open-source licenses, see Robert W. Gomulkiewicz, How Copyleft Uses License Rights to Succeed in the Open Source Software Revolution and the Implications for Article $2 B$, 36 Hous. L. REv. 179 (1999); David McGowan, Legal Implications of Open-Source Software, 2001 U. ILL. L. Rev. 241; Ira V. Heffan, Note, Copyleft: Licensing Collaborative Works in the Digital Age, 49 STAN. L. REv. 1487 (1997).

There are a number of potential problems with such a viral approach. First, it is far from clear that courts would enforce an "agreement" merely attached to a description of an interface standard. In the analogous case of shrinkwrap licenses, courts are sharply divided as to enforceability, with a slight majority holding them unenforceable. See MARK A. LEMLEY ET AL., SOFTwARE AND INTERNET LAW 
So SSO IP rules do not guarantee that a standard is free of IP claims altogether, or that all IP owners have agreed to license their rights on reasonable and nondiscriminatory terms. At most, they clear rights associated with the subset of IP owners who are members of the SSO.

Even members of an SSO will be bound by its bylaw only if that bylaw is an enforceable contract. Whether and how a particular company is bound to obey a bylaw may depend on the form of that company's assent: did it sign a document agreeing to give up rights, or is waiver merely inferred from membership in the SSO? Obviously, the strongest case for enforcement of an IP bylaw is one im which members of the SSO sign contracts committing themselves to comply with the bylaw. Such agreements can be case specific, as where members sign agreements to license patents that cover particular standards on reasonable and nondiscriminatory terms, or they can be general agreements to comply with the rules. There is no reason to think such a signed agreement would not be enforceable. But relatively few SSOs actually include IP policies in a written contract with their members. Indeed, some SSOs don't have membership contracts at all.

A second way by which the bylaws might become binding contracts is incorporation by reference. An SSO's contract might contain a general statement requiring members to read and comply with the SSO's bylaws. Such agreements are relatively common, and should not present siguificant enforceability problems. So long as the member is on notice of the rules with which it must comply, those rules properly can be deemed part of the contract. ${ }^{67}$ The issue is somewhat more problematic if the bylaws change

ch. 6 (2d ed. forthcoming 2003). While this isn't the place for a detailed discussion of the shrinkwrap cases, the reluctance of many courts to infer assent to a variety of terms from the mere act of using a program suggests that a viral approach to standards will be problematic as well. Second, the opensource licenses depend on the existence of a core of copyrightable material that the user can't do without; the theory is that if you don't agree to the terms of the open-source license, you don't get any right to use the original copyrighted material. See Gomulkiewicz, supra; McGowan, supra, at 255; Free Software Found., GNU General Public License (June 1991), at http://www.fsf.org/copyleft/gpl.html. But the copyright status of an industry standard is far more precarious, because copyright doesn't protect functional attributes of a work. 17 U.S.C. $\S 102(b)(2000)$; Lotus Dev. Corp. v. Borland Int'l, 49 F.3d 807 (1st Cir. 1995); Computer Assocs. v. Altai, Inc., 982 F.2d 693 (2d Cir. 1992). For a discussion of the copyrightability of protocols, which are often the subject of industry standard setting, see MARK A. LEMLEY ET AL., SOFTWARE AND INTERNET LAW 167-70 (2000). The only potentially copyrightable portion of an industry standard will thus be the descriptive language of a specification, leaving IP owners who want to avoid assigning their IP rights free to copy the functional aspects of the standard itself. In any event, I am not aware of any SSO that has taken such a viral approach to its IP rules. As a practical matter, therefore, the principle stated in the text is correct: SSO IP rules only bind members of the SSO.

67. See, e.g., Koefoot v. Am. Coll. of Surgeons, 692 F. Supp. 843,860 (N.D. Ill. 1988). This court noted:

Under lllinois law the members of voluntary associations and the associations themselves are contractually bound to follow the bylaws, rules, and regulations of the association. By joining the association, a member accepts this obligation as a condition of menbership. By accepting the member into the association, the association aceepts this obligation as a limitation on its ability to impair the member's status. 
from time to time; presumably the member should be given some notice of the changes. Change is likely to be an issue with respect to IP rules, simce many SSOs adopted or changed their IP rules relatively recently, ${ }^{68}$ and those rules may bind preexisting members of the SSO. Still more problematic are cases in which the bylaw is never agreed to by or brought to the attention of a member, and in which the SSO claims that mere membership in the SSO constitutes agreement to the terms of the rule. Even here, however, the case law strongly suggests that merely joining an SSO is sufficient to constitute consent to be governed by the SSO's bylaws. ${ }^{69}$

Finally, in some circumstances an SSO's IP rule may not be written at all. In at least one case, the Rambus $v$. Infineon litigation discussed below, ${ }^{70}$ the complainant argued that the IP owner should be bound not only by JEDEC's express IP policy, which covered only issued patents, but also by the unwritten understanding of all members that pending patent applications should also be disclosed. Obviously it is preferable for an SSO to set out in writing the obligations of its members. But contracts don't have to be in writing to be binding. Indeed, even an express oral agreement isn't always required. Courts will (and regularly do) imply contracts from sufficient factual circumstances. ${ }^{11}$ Further, the meaming of written or oral contracts will be informed by the norms of an industry and by the particular course of dealing of the parties to the agreement. ${ }^{72}$ Thus, if members of an SSO regularly treat a rule that requires disclosure of patents as also requiring disclosure of patent applications, they may be held to have impliedly agreed to disclose applications. Whether such an agreement will be implied depends on the factual circumstances of the case, and in particular on the state of mind of the parties. Failure to specify the rules in writing invites factual disputes over what the rule is, as in Rambus.

Id.

68. Three examples of SSOs in my study that made or considered changes to their IP rules during the period of the study are the IETF, the W3C, and ETS1. See infra Appendix.

69. See, e.g., Imel v. Zohn Mfg. Co., 481 F.2d I81, I83 (I0th Cir. I973) ("The plaintiffs are members of Local 263. As such they are bound by the constitution and bylaws of the Joint Board and Amalgamated, under which LocaI 263 is an affiliated and subordinate body."); Nelson v. Belle Fourche Irr. Dist., 845 F. Supp. I36I, 1366 (D.S.D. I994) ("As a member and elector of the irrigation district, plaintiff is bound by the district board's bylaws, rules and regulations which dictate the conditions under which plaintiff has a right to receive and use water.'); Laguna Royale Owners Ass'n v. Darger, I74 Cal. Rptr. I36, 138 (Cal. Dist. Ct. App. 1981) ("As owner of a unit in the project, the Dargers automatically became members of the Association and were bound by the Association's bylaws.").

70. Rambus, Inc. v. Infineon Techs. AG, 164 F. Supp. $2 d 743$ (E.D. Va. 2001). See infra notes 154-60 and accompanying text.

71. See, e.g., E. Allen Farnsworth, Contracts $\$ 3.10$ (2d ed. 1990) (explaining that a contract may be formed "by spoken or written words or by other conduct"; those in the latter category are sometimes called "implied-in-fact" contracts).

72. See, e.g., U.C.C. $\$ 1-205$ (2001) (providing that contracts may be interpreted by reference to the course of dealing between parties or within an industry as a whole); RESTATEMENT (SECOND) OF CONTRACTS $\$ \$ 219-222$ (1981); FARNSWORTH, supra note 7I, § 7.13. 


\section{The Effect of Withdrawal}

If an IP owner has entered into a binding contract by joining an SSO, under what circumstances may it terminate that contract? SSO bylaws generally don't have termination dates; the contract thus formed is presumably in force as long as the IP owner is a member of the SSO. The normal rule of contract law is that contracts without a specified term are terminable at will upon reasonable notice to the other party. ${ }^{73}$ Thus, members can presumably withdraw from an SSO at any time upon reasonable notice. But until they do, they will likely be bound by the SSO's IP rules.

Once a member decides to withdraw from an SSO, it may argue that its obligations to license its IP rights terminate immediately. Such a result would be unsatisfactory, however, for at least two reasons. First, it would permit unscrupulous members to "game" the system by withdrawing and then rejoining an SSO in order to avoid having their IP covered by the SSO's rule. To take an extreme example, a member should not be able to propose a standard, withdraw from the SSO shortly before the meeting that adopts that standard (thereby avoiding any disclosure or licensing obligation), and then rejoin the SSO after the standard is adopted. Second, an agreement to license IP rights is presumably an ongoing commitment; indeed, in the absence of an express contractual termination date most courts construe patent licenses to extend until the expiration of the patent. ${ }^{74} \mathrm{~A}$ member that has agreed to license its IP rights covering a standard on reasonable and nondiscriminatory terms has presumably committed to an ongoing license, not a temporary one. For that member to be able to revoke a license already granted for an existing standard when it leaves the SSO would leave users of existing standards with debilitating uncertainty. It would also encourage strategic behavior by firms that promise to license their patents, only to revoke that promise once the standard was widely adopted. ${ }^{75}$

A better approach is to bind members to disclose or license patents that cover any standard adopted or under consideration while the IP owner

73. FARNSWORTH, supra note 71, § 2.14 .

74. See, e.g., Bettis Rubber Co. v. Kleaver, 233 P.2d 82, 84-85 (Cal. Ct. App. 1951). In copyright cases, the issue is more complex. The circuits are split, with some courts finding that a copyright license with no termination provision runs for thirty-five years, and others concluding that such a license is terminable at will. Compare Korman v. HBC Fla., lnc., 182 F.3d I291 (11th Cir. 1999) and Walthal v. Rusk, 172 F.3d 481, 484-85 (7th Cir. I999) (holding that 17 U.S.C. $\$ 203$, which governs the termination of licenses to use copyrighted material, does not create a minimum term for licenses of indefinite duration), with Rano v. Sipa Press, Inc., 987 F.2d 580, 585 (9th Cir. 1993) (holding that 17 U.S.C. $\S 203$ creates a minimum term of thirty-five years for licenses of indefinite duration).

75. Indeed, this sort of behavior was precisely what the Federal Trade Commission ("FTC") alleged to have occurred in the Dell Computer case. See infra notes 149-53 and accompanying text. 
was a member of the SSO. ${ }^{76}$ The disclosure obligation would be satisfied at the time of disclosure, but in some circumstances the licensing obligation would continue beyond the termination of the member's relationship with the SSO. This shouldn't worry us too much, however; contract law frequently enforces particular terms in an agreement even after the relationship has ended. To take just one example, employees and licensees of trade secrets are bound to keep the secret confidential even after their relationship with the trade secret owner terminates. ${ }^{77}$ It seems fair to impose a similar obligation here. Indeed, without such an obligation, a company could effectively revoke its commitinent to an SSO IP rule by withdrawing strategically during the standardization process and then suing other members for infringement once the standard had been set.

\section{Parsing the Terms of Standard-Setting Organization Bylaws}

Assuming that a member is bound to the terms of an SSO IP rule, courts will have to determine exactly what those terms require. As we have seen, there is tremendous diversity in requirements among SSOs. ${ }^{78}$ Their bylaws differ along at least two dimensions: what IP is covered, and what is required of IP owners. While many of the policies are easy enough to interpret-a policy either covers copyrights or it doesn't, for instanceothers are more problematic. In Intel v. VIA Technologies, Inc. ${ }^{79}$ for example, the court had to decide whether a license of a patent that covered a standard covered only the basic features of the standard or included optional ones as well.

What is required of IP owners likewise can present difficult questions. One of the most common requirements imposed on IP owners is an obligation to license IP rights on reasonable and nondiscriminatory terms. But virtually no SSO policies specify what that phrase means, leaving courts to decide what terms are "reasonable." There are presumably easier ways of determining whether a license is "nondiscriminatory," at least in circumstances in which the IP owner has already licensed to others. But even here questions will arise. The IEEE, for example, has taken the position that a refusal to license isn't discriminatory if it is made in response to a lawsuit by the putative licensee. ${ }^{80}$ But whether such an antagonistic situation really

76. A more aggressive approach would bind new members to license patents covering all existing standards promulgated by the SSO. But such a retroactive policy could throw into question preexisting license arrangements, and may therefore be undesirable.

77. See, e.g., Unif. Trade Secrets Act $\$ 1$ (2)(ii)(B)(II), codified at, e.g., CAl. Civ. Code $\$ 3426.1$ (2)(ii)(B)(II) (1997).

78. See supra Part 11.B (discussing this diversity in detail).

79. 174 F. Supp. 2d 1038 (N.D. Cal. 2001).

80. IEEE Policy $\$ 6$. Even the meaning of this policy term is open to interpretation. Some have read the IEEE policy to permit IP owners to avoid licensing anyone with whom they are in a dispute, including a dispute over the fee for the license itself. This is a rather strained reading, as the policy 
justifies a refusal to license patents that cover an industry standard is open to question. ${ }^{81}$

One might argue that the absence of any definition of reasonable terms renders the IP rule hopelessly vague and therefore unenforceable as a contract. After all, if the parties have agreed to license, but haven't agreed on the terms of the license, is there really a meeting of the minds? But it is a well-established principle of contract law that the parties need not specify a price in order to create a binding agreement. In the absence of a price, courts will supply a reasonable and customary price term. ${ }^{82}$ While there is more than just price missing from SSO IP rules-they do not specify the duration of the license, for example-those terms too may be filled in by operation of law. ${ }^{83}$ Application of these contract principles to SSO IP rules suggests that an unspecified "reasonable" royalty term does not leave unbridled discretion with the IP owner to set the terms. Rathcr, courts will determine what royalty is reasonable based on industry custom-here, the treatment of patents of similar scope in related industries. ${ }^{84}$

\section{Enforcement of Bylaws as Contracts}

If a company's nondisclosure of or refusal to license its patent violates an SSO rule requiring disclosure of IP rights, and the SSO rule constitutes a binding agreement, that rule will be enforceable by a claim for breach of contract. However, there are some limitations to the enforceability of such a contract. First, not all of the parties who might be accused of infringing the patent are likely to be members of the SSO, and nonmembers presumably lack standing to sue for breach of contract. Even within an SSO, it isn't altogether clear that members of the SSO, rather than the SSO itself, have standing to enforce the agreement.

would effectively amount to a promise to license the patent only if the parties can agrce on terms. Such a "promise" is no different than the right the IP owner would have had in the abscnce of the policy.

81. In the antitrust context, compare Intergraph Corp. v. Intel Corp., 195 F.3d 1346 (Fed. Cir. 1999) (holding that an IP owner was free to terminate a licensee who sued it for infringement of the licensee's own IP), with In re Intel Corp., No. 9288 (F.T.C. 1999), available at http://www.ftc.gov/ os/1999/9903/d09288intelagreement.htm (forbidding Intel from terminating licensees merely because they sued it, with certain exceptions). See also 1 Herbert HovenKamp et Al., IP and ANTITRust $\S$ 13.4(d) (2002).

82. See, e.g., U.C.C. § 2-305 (2001).

83. Thus, courts regularly conclude that a patent license with no specified term expires when the patent does. See supra note 74. For a more general discussion of terms omitted from contracts that are filled in by operation of law, see FARNSwORTH, supra note $71, \S 7.17$.

84. Courts already make a similar determination in patent infringement cases when the patent owner cannot demonstrate lost profits. See 35 U.S.C. $\$ 284$ (2000). Courts rely on a multifactor test to determine what royalty is reasonable. See, e.g., Georgia-Pacific Corp. v. U.S. Plywood Corp., 318 F. Supp. 1116 (S.D.N.Y. 1970), aff'd in relevant part, Georgia-Pacific Corp. v. U.S. Plywood-Champion Papers, Inc., 446 F.2d 295 (2d Cir. 1971). The fifteen Georgia-Pacific factors have become a standard measure of reasonable royalties in patent cases. See, e.g., Smithkline Diagnostics, Inc. v. Hclena Labs. Corp., 926 F.2d 1161 (Fed. Cir. 1991). 
Contract law distinguishes between parties to a contract and thirdparty intended beneficiaries, both of whom may enforce contracts, and incidental beneficiaries, who generally may not. ${ }^{85}$ Nonmembers of SSOs presumably fall within the latter category, at least absent some express undertaking in the SSO bylaws to the contrary. ${ }^{86}$ Contracts generally aren't interpreted to render the public at large a beneficiary, as a contrary reading would require. ${ }^{87}$ As a result, even if an IP owner has committed herself contractually to license IP, members of the public cannot sue to enforce that contract. This result is somewhat troubling, particularly if the intent of the SSO policy is for IP owners to license everyone on reasonable and nondiscriminatory terms, not just other members. But it seems to be compelled by the limited nature of the legal rules regarding third-party beneficiaries. $^{88}$

Members of the SSO can make a more compelling case that they are the intended beneficiaries of SSO policies. While most contracts involving bylaws are agreements between a member and the SSO itself, the SSO is merely an association that is in turn composed of other members. Many SSOs have no independent staff or structure apart from their membership. It would seem anomalous to permit only the SSO to enforce those bylaws, particularly when the issue will almost always arise in the course of IP litigation between members, not in litigation to which the SSO is a party.

Those who would enforce an SSO IP rule may also be able to seek relief under the doctrine of promissory estoppel. While the law of contracts traditionally did not enforce a promisee's unsolicited reliance on a gratuitous promise, ${ }^{89}$ more modern cases that follow the Restatement (Second) of Contracts permit third parties to recover their reliance interest in certain circumstances. Specifically, the Restatement provides:

A promise which the promisor should reasonably expect to induce action or forbearance on the part of the promise or a third person and which does induce such action or forbearance is binding if injustice can be avoided only by enforcement of the promise..$^{90}$

85. See, e.g., FARNSWORTH, supra note $71, \S 10.3$.

86. REstateMENT (SECOND) Contracts $\$ 302$ (1981).

87. Intended beneficiaries must be specifically identifiable at the time of performance of the contractual obligation. See FARNSworTH, supra note $71, \$ 10.3$. This requirement might be satisfied by waiting until each member of the public comes forward to demand a license, but it is arguable whether the parties to SSO IP rules in fact intend to bring an unknowable class of people within the scope of the contract.

88. The problem may be ameliorated somewhat by the doctrines of estoppel and implied license in IP law. See infra Part III.B for a discussion of those doctrines. Further, at least one court has found a nonmember SSO to be an intended third-party beneficiary entitled to enforce a contract. See ESS Tech v. PC-Tel, No. C-99-20292 at 5 (N.D. Cal. 1999).

89. See, e.g., FARNSWORTH, supra note $71, \$ 2.19$.

90. Resta TEMENT (SECOND) OF CONTRACTS $\$ 90$ (1981). 
To take advantage of this provision, a company would have to demonstrate that it actually relied on the IP owner's promise to license its patents. Of necessity, therefore, the company must have been aware of that promise. The IP owner must also have had reason to know that the company would have expected to benefit from the promise. Assuming both conditions are met, it does seem just to permit both members and nonmembers to benefit from enforcement of the license.

Even once a proper plaintiff to sue for breach of contract has been identified, it isn't clear that any damages remedy would be adequate to compensate for the full social harm caused by the breach. Contractual obligations generally aren't enforced by injunctive relief-here, compelling the IP owner to grant licenses. Rather, the ordinary measure of contract damages is what the party injured by the breach expected to gain from performance of the contract. ${ }^{91}$ In the case of agreements to license on reasonable and nondiscriminatory terms, that expectation is presumably a right to use the patented standard upon payment of a reasonable royalty. If an IP owner breaches such a contract, it may retain the right to enforce its IP rights, but the injured parties would be entitled to recover the value of the use they would have made of the standard, less the royalty they would have paid. ${ }^{92}$ Such a remedy does not fully compensate society for the harm caused by the IP owner's breach, however. Other companies may still be enjoined from using the patented standard, which may create deadweight losses in the market for goods embodying the standard. Further, as noted above, nonmembers may have no remedy for losses they incur as a result of breach.

To some extent, this problem may be solved by specific performance. While contract law normally relies on damages as an exclusive remedy, courts will grant injunctive relief compelling a defendant to perform a contractual obligation if damages would be an inadequate remedy. ${ }^{93}$ Specific performance of an obligation to license on royalty-free or reasonable and nondiscriminatory terms seems particularly appropriate; the defendant had already agreed to give up a legal right in exchange for something of value, and is merely being prevented from asserting the right it had given up. ${ }^{94}$

91. See, e.g., FARNSWORTH, supra note $71, \S \S 12.7-12.8$.

92. This assumes that members have standing to enforce the bylaw; see supra notes 88-89 and accompanying text.

93. See FARNSWORTH, supra note $71, \S 12.6$ (noting that specific performance is possible where damages are inadequate).

94. One possible limit concerns the indefiniteness of a "reasonable and nondiscriminatory" licensing agreement that does not specify terms. While, as noted in the text accompanying note 82 , the failure to specify price or other terms will not void a contract, Farnsworth notes that more definiteness is required to compel specific performance because of the risk that defendant will be held in contempt for failing to perform an unclear contract. Id. $\S 12.7$. But in ESS Tech v. PC-Tel, No. C-99-20292 at 5 (N.D. Cal. 1999), the court found that a promise to license made to an SSO was sufficiently specific to compel performance. 
The remedy problem is even greater for breach of a disclosure obligation. Injunctive relief compelling disclosure isn't a terribly effective remedy; a failure to disclose the existence of an IP right is a problem only if people aren't aware of the IP right, and if they aren't aware of it they can hardly know to sue. ${ }^{95}$ Injured SSOs or members will be able to sue for breach only after they find out about the existence of the right, presumably when the IP owner asserts that right against someone using the standard. Expectation damages will be hard to establish in that situation. They will depend on a court's ability to reconstruct what would have happened in the SSO meeting had the SSO meinbers been aware of the IP right, a difficult task under the best of circumstances. Measuring damages is particularly difficult for those SSOs that compel disclosure but do not coinpel licensing, since it isn't clear that disclosure of a patent would have changed the SSO's decision to adopt a standard. Further, the real harm from nondisclosure-the possibility that an SSO adopted a proprietary standard when it thought it was adopting an open standard, and so helped the IP owner control a market-isn't one that contract law can easily remedy. If mefficient breaches of SSO bylaws are to be discouraged, the remedy will have to be found elsewhere.

One possibility is for the SSO itself to specify the sanction for breach. For example, the old ETSI policy provided that members must agree to license their patents on "fair, reasonable, and non-exclusive" terms to other ETSI members. If a member refused to do so, the sanction was a loss of IP licenses from all other members. ${ }^{96}$ Other SSOs might similarly try to remedy social harms by specifying a substantial sanction for breach, but such provisions are likely to run afoul of the general rule of contract law that prohibits penalty damages. ${ }^{97}$

\section{Conclusion}

Even if SSO IP rules are enforceable contracts, the law of contracts has loopholes. IP owners who agree to an SSO bylaw and then breach that agreement are unlikely to internalize the full costs of that breach. They may induce reliance by third parties that have no right to enforce the contract. They may enforce their IP rights against a marketplace that adopted a standard with the expectation that it was not proprietary, enjoining competitors and recovering supracompetitive profits while being forced to pay

95. Such an injunction might be useful in a continuing relationsbip against a pattern of nondisclosure, but only if the injunction is written broadly enough that nondisclosure in a different context would constitute contempt.

96. For a description of this policy, see Rudi Bekkers \& Isabelle Liotard, European Standards for Mobile Communications: The Tense Relationship Between Standards and Intellectual Property Rights, 21 Eur. Intell. Prop. Rev. 110, 121 (1999). ETSI changed its standard to a weaker nondisclosure requirement under pressure from the United States. See id. at 122.

97. See, e.g., U.C.C. \$ 2-718 (2001); FARNSWORTH, supra note 71, \$12.18. 
only expectation damages. The possibility of breach without serious consequences is even greater when the obligation breached involves only disclosure and not licensing. In such cases, it isn't clear that contract law provides any effective remedy for the injuries such a breach causes the $\mathrm{SSO}$, its members, and the general public.

\section{B. Enforceability Under Intellectual Property Law}

Because of the problems with contractual enforcement of SSO IP rules, those injured by an IP owner have turned to IP law itself to "enforce" SSO bylaws. At least two related patent-law doctrines may apply when a patent owner has failed to comply with SSO rules: equitable estoppel and implied license. Which doctrine is most applicable depends upon which obligation the patent owner is accused of violating: disclosure or reasonable and nondiscriminatory licensing.

\section{Disclosure Obligations and Equitable Estoppel}

The most likely candidate for dealing with a failure to disclose IP rights is the doctrine of equitable estoppel. Equitable estoppel applies where "a patentee, through misleading conduct, leads the alleged infringer to reasonably infer that the patentee does not intend to enforce its patent against the alleged infringer. Conduct may include specific statements, action, inaction, or silence where there was an obligation to speak." 98 To use equitable estoppel as a defense to infringement, the infringer must show that it relied on the misleading conduct and will be materially prejudiced if the patent is enforced. ${ }^{99}$

For several reasons, the equitable estoppel doctrine is particularly well suited to dealing with IP owners who fail to disclose their IP rights. ${ }^{100}$ First, the doctrine does not require affirmatively misleading statements, but also applies to silence in circumstances where there "was a clear duty to speak." obligation as a contractual matter, violating that duty may give rise to estoppel. Second, the estoppel cases do not require proof of intent to mislead. Rather, the only question is whether the patent owner's "course of conduct reasonably gave rise to an inference" that it would not enforce the patent. ${ }^{102}$ Thus, estoppel should apply even in the relatively common case in which a patent owner's failure to disclose was inadvertent or merely negligent, and

98. A.C. Aukerman Co. v. R.L. Chaides Constr. Co., 960 F.2d 1020, 1028 (Fed. Cir. 1992) (in banc).

99. Id.

100. For a discussion of equitable estoppel as applied to nondisclosure of patents to SSOs, see David M. Schneck, Setting the Standard: Problems Presented to Patent Holders Participating in the Creation of Industry Uniformity Standards, 20 Hastings CoMm. \& ENT. L.J. 641, 649-51 (1998).

101. A.C. Aukerman, 960 F.2d at 1028.

102. Id. 
not part of a scheme to deceive the SSO. ${ }^{103}$ Finally, unlike the limited remedies available in contract cases, proof of equitable estoppel will bar the IP owner from any relief. ${ }^{104}$ As a result, IP owners who violate a disclosure obligation-thereby inducing members of an SSO to believe they have no patents covering the standard or will not enforce them-may be precluded from obtaining damages or injunctive relief against those members.

\section{a. Application to Standard-Setting Organization Rules}

There are a number of cases suggesting that companies who fail to disclose a known patent to an SSO niay be estopped from later asserting that patent against members of the SSO once it has adopted the patented technology as a standard. ${ }^{105}$ In Stambler v. Diebold, Inc., for example, the court found estoppel on the basis of conduct before an SSO even in the absence of an SSO rule requiring disclosure:

Ten years before this suit was filed, plaintiff concluded that the proposed Thrift or MINTS standard imfringed his patent. It was well known to plaintiff and throughout the industry that the same provisions the plaintiff is relying on for infringement were being contemplated as national and imternational standards. Moreover, in the mid-1970's plaintiff sat on an American National Standard Institute standards committee after concluding that the proposed Thrift and MINTS standards infringed his patent. Plaintiff subsequently left the cominittee without notifying it of the alleged infringement of his patent. Under these circumstances, plaintiff had a duty to speak out and call attention to his patent. Plaintiff contacted defendant only once, ten years before this suit was filed. In 1975, plaintiff testified that he believed defendant as infringing his patent. However, plaintiff failed to bring suit until ten years later. Plamtiff had a duty to speak out and his silence was affirmatively misleading. Plamtiff could not remain silent while an entire industry implemented the proposed standard and then when

103. Contrast this with the rule in antitrust cases, which at least nominally requires proof of intent to monopolize. See Herbert HovenKamp, Federal Antitrust Policy $\$ 6.4 c$ (1994).

104. A.C. Aukerman, 960 F.2d at 1028.

105. See Stambler v. Diebold, Inc., 11 U.S.P.Q.2d 1709, 1714-15 (E.D.N.Y. 1988), aff'd 878 F.2d 1445 (Fed. Cir. 1989) (unpublished); Potter Instrument Co. v. Storage Tech. Corp., 207 U.S.P.Q. 763, 766-67 (E.D. Va. 1980), aff'd 641 F.2d 190 (4th Cir. 1981); see also Wang Labs., Inc. v. Mitsubishi Elecs. Am., Inc., 29 U.S.P.Q.2d 1481, 1495-96 (C.D. Cal. 1993) (holding that an equitable estoppel claim raised a triable issue of fact). The Fourth Circuit did not reach the equitable estoppel issue in Potter Instrument, but indicated in dictum that it would be inclined to find such an estoppel. Potter Instrument, $641 \mathrm{~F} .2 \mathrm{~d}$ at 192 . Estoppel from misleading silence is possible, but rare, under Federal Circuit precedent. See Jamesbury Corp. v. Litton Indus. Prods., Inc., 839 F.2d 1544, 1553 (Fed. Cir. 1988) (minority opinion). 
the standards were adopted assert that his patent covered what manufacturers believed to be an open and available standard..$^{106}$

Stambler is arguably too sweeping, since it applies estoppel from silence even in the absence of an express duty to speak. But it certainly suggests that a party who breaches an express duty may be estopped from later enforcing a patent. Similarly, even in the absence of an express duty to disclose, affirmatively misleading statements about IP to an SSO should give rise to estoppel. For example, if a company consistently represents to an SSO that its proposed standards are "open" or "non-proprietary," it may be estopped from later asserting IP rights that cover those standards even if the SSO had no policy on the subject. ${ }^{107}$

One limit on the application of equitable estoppel in the SSO context concerns its use by nonmembers of the SSO ${ }^{108}$ Because equitable estoppel requires reliance by the defendant to its detriment, accused infringers can invoke estoppel only if they actually relied on the IP owner's statements (or silence) in determining their course of conduct. At a minimum, reliance requires that the accused infringer be aware of the statements. But the Federal Circuit's treatment of the issue seems to require more:

Reliance is not the same as prejudice or harm, though frequently confused. An infringer can build a plant being entirely unaware of the patent. As a result of infringement, the infringer may be unable to use the facility. Although harmed, the infringer could not show reliance on the patentee's conduct. To show reliance, the infringer must have had a relationship or communication with the plaintiff which lulls the infringer into a sense of security ... ${ }^{109}$

While one might read this to suggest that the patent owner must communicate directly with the accused infringer, ${ }^{110}$ in the context of standard setting such a reading is too narrow. Where the patent owner has made a representation to the SSO about its IP rights, and that representation is publicly available, ${ }^{111}$ nonmembers should reasonably be able to rely on those representations. Similarly, where a patent owner has told the SSO that it has no patents that cover a proposed standard, accused infringers who know of

106. 11 U.S.P.Q.2d at 1712.

107. Cf. Wang Labs., Inc. v. Mitsubishi Elecs. Am., Inc., 103 F.3d 1571 (Fed. Cir. 1997) (finding that representations of openness to the marketplace could bind patentee). A similar issue arose with Sun Microsystems and the Java standard. These issues are discussed in more detail in Lemley \& McGowan, supra note 40, at 770-72 (suggesting that Sun be bound by a sort of open-systems estoppel).

I08. Another issue is whether a misrepresentation must be intentional. For an argument that gross negligence should suffice, see Cowie \& Lavelle, supra note 11, at 106-08.

109. A.C. Aukerman, $960 \mathrm{~F} .2 \mathrm{~d}$ at 1043.

110. See, e.g., Mueller, Misuse, supra note 8, at 659 ("Third parties who did not participate in the standards-setting activity and had no contact with the patentee would be unable to establish detrimental reliance.").

111. See, e.g., Internet Eng'g Task Force, supra note 60 (collecting notices by IP owners of rights that are claimed in 1ETF standards). 
that statement should be entitled to rely on it. Because the purpose of the patent owner's statement is to induce reliance, courts should be inclined to find such reliance. Of course, the mere existence of a public statement won't always prove reliance. If there is no evidence that the accused infringer was aware of the statement, or if the evidence suggests it expected the patent to be enforced but thought a lawsuit was an acceptable business risk, estoppel should not apply. ${ }^{112}$

Whether reliance on an affirmative statement that a company doesn't own any patents that cover a standard is appropriate might be thought to depend on the alternative ways SSOs and members might learn about the patents. When the IP owner possesses only an unpublished patent application, it would be virtually impossible for competitors to acquire information about this potential IP right, except from the patent applicant herself. In this situation, reliance is clearly appropriate. Where a patent has been issued or the patent application published, on the other hand, it is possible for the SSO to search the patent literature to ensure that no patents cover the proposed standard. Some might argue, therefore, that SSOs should not be entitled to rely on statements made by the IP owner. Even in this latter case, however, I do not believe reliance is inappropriate. Such a search is costly and imperfect. Imposing such a requirement on SSOs will therefore not necessarily prevent the patent owner from using a lack of information to her advantage. In either case, therefore, the SSO may lack relevant information if the patent owner fails to disclose the existence of a patent. Finally, even if an accused infringer is aware of the existence of a patent, it might reasonably rely on the patent owner's statement as evidence that the patent owner doesn't consider the patent relevant to the standard, or is willing to abandon its rights.

\section{b. Application Outside of Standard-Setting Organizations}

Application of equitable estoppel may not be limited to representations made to SSOs. Rather, a number of cases, including Stambler, ${ }^{113}$ have applied estoppel to statements made to the marketplace. Thus, in Wang Labs., Inc. v. Mitsubishi Elecs. Am., Inc., ${ }^{114}$ the court held that the defendant could maintain an estoppel defense by alleging that Wang Labs had represented to customers that its standard would remain open. This is

112. See Winbond Elecs. Corp. v. ITC, 275 F.3d 1344 (Fed. Cir. 200I) (denying an estoppel claim where the defendant conceded it had no knowledge of the patentee's statements to an SSO); Hall v. Aqua Queen Mfg., Inc., 93 F.3d I548 (Fed. Cir. I996) (denying an estoppel claim where the accused infringer acted on belief that the patent was invalid, not on the basis of representations by the patentee); Hemstreet v. Computer Entry Sys., Inc., 972 F.2d 1290 (Fed. Cir. 1992) (denying an estoppel claim where the accused infringer didn't rely on Hemstreet's actions, but rather on its own business judgment about the risk of being sued). Cf. Gasser Chair Co. v. Infanti Chair Mfg. Corp., 60 F.3d 770 (Fed. Cir. I995) (holding that conclusory evidence of reliance was insufficient to constitute estoppel).

113. See supra note 105 and accompanying text.

114. 103 F.3d I57I (Fed. Cir. 1997). 
important because de facto standard setting can also be influenced by misleading statements about the open nature of a standard.

Wang Labs is a fairly easy case because of the affirmative nature of the representations that were later used to bind the company. But a number of claims have involved silence and failure to sue during the critical formation period of a de facto standard. For example, one significant dispute involved the most common standard for file exchange of graphics over the Internet during the early I990s: the "GIF" standard. No SSO set GIF as a standard; rather, after GIF was released by Compuserve in 1987, it was apparently free for all to use and was gradually adopted by a number of Internet users (as well as developers of extension programs) during the late 1980s and early 1990s. In 1986, Unisys Corporation obtamed a patent that arguably covered the compression algorithm used by the GIF standard (the LZW patent). Unisys kept silent about the patent while the GIF standard gained market share; whether intentionally or because they were unaware of the GIF-LZW overlap is unclear. Beginning in 1994, however, it asserted the patent against Compuserve and other companies that transferred graphics over the Internet using the standard, a group that included virtually every major company on the Internet at one point in time. ${ }^{115}$ Although Unisys made no affirmative representation that the standard was not proprietary, its silence during the crucial period of standards competition allowed it to take a more mature industry by surprise. ${ }^{116}$

Some cases have held that silence in the face of known infringement can rise to the level of estoppel. For example, in Stryker Corp. v. Zimmer, Inc., ${ }^{117}$ the court held that a delay of four years after discovery of infringement not only barred damages claims under the principle of laches but also estopped any prospective relief against the defendant. ${ }^{118}$ The Federal Circuit has been somewhat more dubious of such claims, however, and recent cases are divided in their treatment of claims based solely on silence in the marketplace. ${ }^{119}$ One of the difficulties with such claims is proof of reliance. It isn't sufficient that an accused infringer benefit from nonenforcement of a patent; they must reasonably rely on the patent owner's

115. Efforts to enforce the patent continue today. See Evan Hansen, Patent Demands May Spur Unisys Rivals in Graphics Market, CNET NEws.COM, at http://news.cnet.com/news/0-1005-2001713278.html (Apr. 18, 2000).

116. For a discussion of this case, see Lemley, supra note 11 , at 1087.

117. 741 F. Supp. 509 (D.N.J. 1990).

118. The doctrine of laches is based on unreasonable delay, and bars only retrospective relief. By contrast, the doctrine of estoppel completely bars enforcement of the patent. For a discussion of the two doctrines, which are frequently intertwined, see A.C. Aukerman Co. v. R.L. Chaides Constr. Co., 960 F.2d 1020,1020 (Fed. Cir. 1992) (in banc).

119. See, e.g., B. Braun Med., Inc. v. Abbott Labs., 124 F.3d 1419 (Fed. Cir. 1997) (rejecting liability based merely on silence in the marketplace); Hemstreet v. Computer Entry Sys. Corp., 972 F.2d 1290 (Fed. Cir. I992) (same). But see Scholle Corp. v. Blackhawk Molding Co., 133 F.3d 1469 (Fed. Cir. I998) (finding liability in such a circumstance); ABB Robotics, Inc. v. GMFanuc Robotics Corp., 52 F.3d 1062 (Fed. Cir. 1995) (same). 
silence as an indication that the patent will not be enforced. ${ }^{120}$ Where, as in the GIF case, it is likely that those using the GIF standard had no relationship with Unisys at all and knew nothing of the LZW patent, it is hard to see how they could have relied on Unisys not to enforce that patent. More generally, estoppel by silence in the marketplace, unlike silence in the face of an SSO IP rule, effectively creates an affirmative duty to "police" patent infringement. This may not be wise as a policy inatter. ${ }^{121}$

\section{Reasonable and Nondiscriminatory Licensing Obligations and Implied License}

Equitable estoppel is unlikely to apply to a situation where a patent owner has disclosed the existence of a patent but promised to license it on reasonable and nondiscriminatory terms. A patentee who has made such a promise has not induced others to believe it will not enforce the patent; far from it. The patentee has made an affirmative statement that it intends to enforce the patent, putting the world on notice that they must expect to pay royalties if they are to use the proposed standard. ${ }^{122}$ As a result, even if the IP owner breaches the agreement to license on reasonable and nondiscriminatory terms, traditional equitable estoppel doctrine seems unlikely to apply. ${ }^{123}$

Nonetheless, patent law may well limit the ability of a patentee to ignore SSO IP rules requiring licensing on reasonable and nondiscriminatory terms. The most likely theory is a license implied from the patentee's conduct, which I will call an "implied license." 24 Inplied license is a doctrine

120. See Sony Elecs., Inc. v. Soundview Techs., Inc., 157 F. Supp. 2d 172, $178-79$ (D. Conn. 2001) (rejecting estoppel claim based on silence before the FCC, since Sony could not prove it relied on that silence). Sony expressly distinguished silence in the face of an SSO IP rule requiring disclosure. Id.

121. See Wanlass v. General Elec. Co., 148 F.3d 1334 (Fed. Cir. 1998) (holding that estoppel doctrine creates a duty to police patent rights); $c f . i d$. at 134I-43 (Rader, J., dissenting) (objecting to the creation of this duty).

122. Soine cases find estoppel from a threat of enforcement followed by a period of silence. See, e.g., Scholle Corp. v. Blackhawk Molding Co., I33 F.3d I469 (Fed. Cir. 1998); ABB Robotics, Inc. v. GMFanuc Robotics Corp., 52 F.3d 1062 (Fed. Cir. 1995). As a result, estoppel may apply to those who identify patents that they intend to license but then do nothing about licensing them for an extended period of time.

123. A stronger equitable estoppel case may be made in those few SSOs that require royalty-free licensing. An IP owner that discloses a patent to such an SSO may reasonably be thought to be representing that the patent is available royalty-free, inducing reliance by accused infringers.

124. In Wang Laboratories, Inc. v. Mitsubishi Electronics America, Inc., 103 F.3d 1571, 1580 (Fed. Cir. 1997), the Federal Circuit annonneed that acquiescence, implied license by conduct, equitable estoppel, and legal estoppel were all part of the same legal doctrine of implied license. This conclusion is certainly questionable as an historical matter. For an excellent discussion of implied license in historical context, see 5 Donald S. Chisum, Chisum on Patents $\$$ I6.03 (2002); Mark D. Janis, A Tale of the Apocryphal Axe: Repair, Reconstruction, and the Implied License in Intellectual Property Law, 58 MD. L. REv. 423 (I999). But as a practical matter, it inakes little difference what label we put on the doctrine. The fact of the matter is that a license implied from an IP owner's conduct in the marketplace is a "different category of conduct" from equitable estoppel. Wang Labs., 103 F.3d 
of quasi contract, and depends on the beliefs and expectations of the parties to the sales transaction. ${ }^{125}$ It is most commonly applied in cases where the product sold by the patentee isn't itself patented, but is necessary for use in a patented process. Courts typically conclude that the sale of a product by the IP owner necessarily carries with it the right to use the patented process for which the product is adapted. ${ }^{126}$ Other uses of implied license in IP law include cases in which the plaintiff develops a product for use by the defendant, but retains the copyright. In such cases the courts will permit reasonable uses by the defendant. ${ }^{127}$ Implied license is also likely where an IP owner invites a use that would otherwise infringe, for example, by posting their copyrighted work on the Internet for free download. ${ }^{128}$

The last situation is perhaps most analogous to standard setting. If an IP owner agrees to license its patents that cover a standard on reasonable and nondiscriminatory terms, others will assume that they are free to use that standard so long as they pay a reasonable royalty. There may be no express license between the IP owner and any of the users of the standard, but it seems perfectly reasonable to imply one from the conduct of the IP owner. ${ }^{129}$ Indeed, Wang Labs itself involved not only representations in the

at 1580 . In this Section, I will use the term "implied license" to refer to a license implied from market conduct.

There is some question as to whether implied licenses in IP are creatures of state or federal law. Patent licenses are normally construed as a matter of state contract law. But Wang Labs. seemed to treat the implied license question as one of federal law, and the Federal Circuit has increasingly treated contractual questions surrounding patent licenses as matters of federal common law. See, e.g., RhonePoulene Agro, S.A. v. DeKalb Genetics Corp., 271 F.3d 1081 (Fed. Cir. 2001) (holding that bona fide purchaser defense for licenses was a question of federal common law); cf. Everex v. Cadtrak, 89 F.3d 673 (9th Cir. 1996) (holding assignability of nonexclusive patent licenses presented a question of federal law); Mark A. Lemley, Beyond Preemption: The Law and Policy of Intellectual Property Licensing, 89 CALIF. L. REV. 111 (1999) (noting a tendency to treat licensing policy questions under federal common law). By contrast, courts treat questions of implied copyright license under state law. See, e.g., Foad Consulting Group, Inc. v. Musil Govan Azzalino, 270 F.3d 821 (9th Cir. 2001).

125. E.g., Withington-Cooley Mfg. Co. v. Kinney, 68 F. 500, 506 (6th Cir. 1895) ("The duration and scope of a license must depend upon the nature of the invention and the circumstances out of which an implied license is presumed, and both must at last depend upon the intention of the parties."); Janis, supra note 124, at 502-505 (noting the critical role that intent of the parties plays in determining the scope of an implied license). But cf. Carborundum Co. v. Molten Metal Equip. Innovations, Inc., 72 F.3d 872, 877 (Fed. Cir. 1995) ("Whether there existed an implied license is a question of law.").

126. See, e.g., United States v. Univis Lens, 316 U.S. 241 (1942).

127. See, e.g., Effects Assocs., Inc. v. Cohen, 908 F.2d 555 (9th Cir. 1990) (concluding that a movie studio that paid to have special effects produced had an implied license to use those special effects in a movie that it distributed).

128. See David Nimmer, Brains and Other Paraphernalia of the Digital Age, 10 HARV. J.L. \& ТЕсн. 1, 39 (1996). For an argument that implied license has some troubling limits in the Intemet context, see Mark A. Lemley, Dealing with Overlapping Copyrights on the Internet, 22 U. DAYTON L. REv. 547, 567 (1997).

129. In Sony Electronics, Inc. v. Soundview Technologies, Inc., the court concluded that Soundview had not impliedly licensed its patents covering V-chip television filtering technology merely because the government required the installation of V-chips. $157 \mathrm{~F}$. Supp. $2 \mathrm{~d} 172$ (D. Conn. 2001). Sony had argued that it was entitled to a royalty-free license because the government required the technology to be used. The court disagreed, finding both that the government did not inandate the 
marketplace, but also Wang Labs' efforts to persuade JEDEC to adopt its proposed industry standard. ${ }^{130}$

While an implied license of this sort may seem superfluous in view of the IP owner's contractual obligations described in the previous Section, there is an important difference between a license under IP law and a contractual obligation to license: the remedy. As we have seen, the remedy for breach of a contractual obligation to license isn't judicial imposition of a license, but merely expectation damages resulting from the breach. Those damages are likely to be insufficient to compensate accused infringers and society at large for the losses they will suffer if they are enjoined from using standards once thought open to all. ${ }^{131}$ By contrast, if a court determines that an IP owner granted a license by virtue of agreeing to be bound by an SSO IP rule, the only remaining questions concern the scope of the license and the royalty rate. The IP owner in that case has only a contractual claim for a royalty, not a cause of action for patent infringement that might result in an injunction, treble damages, and attorneys' fees. The practical difference is dramatic.

1 am aware of no cases treating this issue. I think it is preferable as a policy matter to construe an IP owner's agreement to an SSO IP-licensing requirement as the grant of a license itself, rather than merely a contract with the SSO. Such an approach has several advantages. First, it ensures that all users of the standard benefit from the license, even if they would be unable to sue for breach of the SSO contract itself. This is what the SSO rules almost certainly intend. Second, it sharply narrows the scope of the issues that must be litigated in these cases and, relatedly, makes it possible for the SSO to resolve those issues ex ante. SSOs might try to set standards for determining a reasonable royalty in a license agreement; they would presumably have no power to do so if the IP owner retained a right to sue for infringement. Third, and most importantly, the implied-license approach reduces opportunism by IP owners. Under the contract approach, IP owners have an incentive to assert claims for patent infringement against users of well-established standards, even if the owners previously agreed to license those patents on reasonable and nondiscriminatory terms. By threatening to prevent use of the standard, they can coerce significantly more than a reasonable royalty from users. Determining that IP owners have already licensed their patents prevents such opportunism. It may also reduce the need for the courts to rely on mechanisms like antitrust and fraud, discussed below, to deal with such opportunism.

choice of Soundview's particular technology as the implementing standard and that in any event the government could compel the use of patented technology so long as the royalties charged were reasonable. Id. at 177. Nothing in Sony suggests that conduct before an SSO cannot give rise to an implied license.

130. Wang Labs., Inc. v. Mitsubishi Elecs. Am., Inc., 103 F.3d 1571, 1575 (Fed. Cir. 1997).

131. See supra Part III.A.4. 
The license approach may have one rather unfortunate jurisdictional consequence. Because disputes over the terms of a license are questions of state contract law, they will be decided in state rather than federal court. ${ }^{132}$ Even if there is an independent basis for federal jurisdiction (diversity or another federal question), contractual disputes over license terms do not arise under 28 U.S.C. $\S 1338^{133}$ and so will not go to the Federal Circuit on appeal. ${ }^{134}$ This may be troubling, especially to those who see the Federal Circuit as a force for uniformity not only in patent law but also in related cases. ${ }^{135}$ But questions involving patent law have never been the exclusive domain of federal courts in general or the Federal Circuit in particular. Some cases always have gone to state courts because the underlying dispute concerned the terms of an agreement, rather than patent infringement. ${ }^{136}$ Perhaps standard-setting cases should be no different.

If the jurisdictional question does present a serious problem, one possible solution is for the Federal Circuit to decide that implied, as opposed to express, licenses are questions of federal patent law. This would presumably entail deciding that the licenses in question were implied in law rather than implied in fact. ${ }^{137}$ Certainly such cases are likely to arise, at

132. See, e.g., Mark J. Henry, State Courts Hearing Patent Cases: A Cry for Help to the Federal Circuit, 101 Dick. L. Rev. 41, $44-49$ (1996) (explaining the basis for "arising under" federal jurisdiction, and how it is limited to suits for patent infringement or declaratory judgment, but does not cover other disputes that involve a patent).

133. 28 U.S.C. $\$ 1338(2000)$ (providing for federal jurisdiction over cases arising under the patent laws); Holmes Group, lnc. v. Vornado Air Circulation Sys., 122 S.Ct. 1889 (2002).

134. See 28 U.S.C. $\$ 1295$ (2000) (providing that Federal Circuit jurisdiction extends to cases that arise under section 1338 in whole or in part).

135. The Federal Circuit has increasingly asserted its authority outside of traditional patent law to encompass related state and federal law questions. See, e.g., Semiconductor Energy Lab. Co. v. Samsung Elecs. Co., 204 F.3d 1368, 1379 (Fed. Cir. 2000) (holding that predicate acts for RICO claims will be decided as a matter of Federal Circuit law); Univ. of Colorado Found. v. Am. Cyanamid Co., 196 F.3d 1366 (Fed. Cir. 1999) (holding that inventorship under state tort law will be decided under Federal Circuit standards); Midwest Indus., Inc. v. Karavan Trailers, Inc., 175 F.3d 1356 (Fed. Cir. 1999) (holding that state laws that relate to patent conduct will be interpreted under Federal Circuit law); Nobelpharma AB v. Implant Innovations, Inc., 141 F.3d 1059 (Fed. Cir. 1998) (holding that antitrust questions will be decided under Federal Circuit law); Deirdre L. Conley, Note, Nobelpharma AB v. Implant Innovations Inc., 14 BerKeley TECH. L.J. 209 (1999) (discussing the expansion of Federal Circuit jurisdiction).

The stated goal of this increase in control is to establish uniformity in patent-related doctrines. Whether the Federal Circuit has increased uniformity in patent law is itself a matter of some dispute. See, e.g., Matthew F. Weil \& William C. Rooklidge, Stare Un-Decisis: The Sometimes Rough Treatment of Precedent in Federal Circuit Decision-Making, 80 J. PaT. \& TRademark OfF. Soc'y 791 (1998).

136. See Henry, supra note 132, at 47 (stating that "a suit for damages on a patent license or patent assignment isn't considered to be a federal remedy" and so is heard by state courts); cf. Holmes Group, 122 S.Ct. at 1897-98 (Stevens, J., concurring) (arguing that some jurisdictional diversity is a healthy thing in patent law).

I37. Cf. F. Jay Dougherty, Not a Spike Lee Joint? Issues in the Authorship of Motion Pictures Under U.S. Copyright Law, 49 UCLA L. Rev. 225, 332 (2001) (suggesting that licenses should be implied in copyright law). 
least initially, as defenses to patent-infringement suits that the Federal Circuit would likely hear anyway. ${ }^{138}$ The court may be able to expand its authority to decide such questions as a matter of Federal Circuit law. ${ }^{139}$ Whether it can or not, the number of cases is likely to be fairly modest, and the primary issue those cases present-what is a reasonable royalty-is fact specific and not dependent on general legal principles.

\section{Tort Liability for Nondisclosure of Intellectual Property}

While contract and estoppel-based IP theories may help to enforce SSO IP rules against recalcitrant IP owners, both have their shortcomings. Contract provides only weak remedies, especially for violation of a disclosure rule, and estoppel and implied license are at most defenses to be asserted when an SSO member is sued for infringement. SSO meinbers have understandably sought a more robust affirmative claim agamst IP owners who misrepresent the legal status of a standard. Accordingly, SSO members have turned to two possible tort claims: antitrust and fraud.

\section{Antitrust Theories of Liability ${ }^{140}$}

Antitrust law is designed to protect the integrity of market competition against attempts to raise prices and reduce output, either by a single firm that dominates the market and excludes competition or by a group of firms that act collectively to coordinate their price and output decisions. In the context of SSO IP rules, an antitrust claim against an IP owner likely will focus on the competitive advantage the IP owner receives by misleading the SSO members into adopting a standard they believe to be free to use, but which $\mathrm{m}$ fact is owned by the defendant. In private actions, antitrust claims offer plaintiffs the lure of treble damages and attorney's fees, ${ }^{141}$ as well as the possibility of enforcement by federal or state antitrust authorities.

The most likely avenue of antitrust attack ${ }^{142}$ against efforts to control the standard-setting process by failure to disclose an IP right is an

138. Even if the putative licensee is the plaintiff, federal courts normally still have jurisdiction under the Declaratory Judgments Act as long as the licensee is under imminent threat of suit and seeks a declaration that the patent is invalid or not infringed. See Foster v. Hallco Mfg. Co., 947 F.2d 469 (Fed. Cir. 1991); C.R. Bard, Inc. v. Schwartz, 716 F.2d 874 (Fed. Cir. 1983).

139. The Supreme Court limited the jurisdiction of the Federal Circuit in Holmes Group, 122 S.Ct. 1889 (2002), but has not placed any limits on the Federal Circuit's increasing tendency to decide nonpatent law questions under Federal Circuit rather than regional circuit law. $C f$. Mark D. Janis, Patent Law in the Age of the Invisible Supreme Court, 2001 U. ILL. L. REv. 387 (lamenting the reluctance of the Supreme Court to intervene in patent cases).

140. Portions of this Subsection have been republished in adapted form in 2 HoveNKAMP ET AL., supra note $34, \$ 35.6$.

141. 15 U.S.C. $\$ 15(2000)$.

142. Janice Mueller has suggested an alternative approach: application of the patent misuse doctrine to enforce a disclosure obligation. See Mueller, Misuse, supra note 8.1 discuss this approach in more detail below. Infra notes 187-92 and accompanying text. 
attempted monopolization claim under section 2 of the Sherman Act. ${ }^{143}$ Attempted monopolization has three elements: (1) a specific intent to monopolize; (2) anticompetitive conduct in furtherance of that intent; and (3) a dangerous probability of successful monopolization. ${ }^{144}$ Even a full-blown monopolization claim requires proof of conduct "willfully intended" to further the acquisition or maintenance of monopoly power. ${ }^{145}$ As a result, market power, anticompetitive conduct, and intent all must be proven to make out an antitrust violation, whether the claim is based on monopolization or attempted monopolization. ${ }^{146}$

In several recent cases, antitrust plaintiffs have alleged that a defendant persuaded an SSO to adopt its proposed standard by misrepresenting its status as IP. ${ }^{147}$ This misrepresentation sometimes takes the form of an omission, such as failing to assert ownership in the standard publicly until after it is adopted, and sometimes the form of an affirmative falsehood like signing a statement indicating that the party has no IP rights in the proposed standard. ${ }^{148}$ Two examples follow, presenting somewhat different issues.

In 1992, the Video Electronics Standards Association ("VESA") adopted a computer hardware standard called the VL-Bus standard, which governs the transmission of information between a computer's CPU and its peripheral devices. ${ }^{149}$ Each of the members who voted to adopt the standard, including Dell Computer Corporation, was required by VESA rules to affirm that it did not own any patent rights that covered the VL-Bus standard, and Dell's representative did in fact make such a statement. ${ }^{150}$ Nonetheless, Dell owned a patent that covered the standard and asserted it against other VESA members using the VL-Bus standard eight months

143. See infra note 149 and accompanying text. The FTC brought a claim against Dell not for violation of the Sherman Act, but rather under section 5 of the Federal Trade Commission Act, which is enforceable only by the FTC. Section 5 generally tracks the requirements of section 2 of the Sherman Act. See Fed. Trade Comm'n v. Sperty \& Hutchinson Co., 405 U.S. 233 (1972); 2 Philip E. AreEdA \& Herbert Hovenkamp, Antitrust Law $\mathbb{} 302$ (2d ed. 2000).

144. Spectrum Sports v. McQuillen, 506 U.S. 447, 456 (1993). See 3A PHILIP E. AREedA \& Herbert Hovenkamp, Antitrust Law qfil 804-808 (2d ed. 2000); 2 Hovenkamp et al., supra note $34, \$ 10.4$.

145. United States v. Grinnell Corp., 384 U.S. 563, 570 (1966).

146. Even under broader statutes such as the Federal Trade Commission Act, 15 U.S.C. \$ 45 (2000), which isn't bound by the limits of section 2 of the Sherman Act, only intentional misrepresentations should constitute anticompetitive conduct. While an accidental failure to disclose the existence of a patent might have anticompetitive consequences, that sort of mistake is not the kind of conduct that should be punished as an antitrust violation.

147. See cases discussed in Part III.C.1.

148. For a discussion of the problem of strategic misrepresentations and failures to disclose, see Kipnis, supra note 11 , at 102.

149. See In re Dell Computer Corp., No. $931-0097$ (F.T.C. 1995).

150. Id. Many SSOs, including the American National Standards Institute ("ANSl") and Semiconductor Equipment and Materials International ("SEMI"), have similar rules. See infra Appendix. 
later, after the VL-Bus standard had been widely adopted in the marketplace. ${ }^{151}$ Because Dell worked to have a technology it allegedly knew was proprietary adopted as a group standard, ${ }^{152}$ the Federal Trade Commission ("FTC") argued that Dell effectively sought to enlist its competitors in establishing a standard that it ultimately would be able to control. Dell and the FTC ultimately entered into a consent decree in which Dell agreed not to assert its IP rights in the VL-Bus. ${ }^{153}$

More recently, Infineon alleged that Rambus had asserted against it a patent obtained by fraud. ${ }^{154}$ Infineon argued that Rambus had filed patent applications that related to a standard for DRAM devices, waited until the standard was adopted, and then modified its patent applications so that the claims covered the standards. The standard was adopted by JEDEC, of which Rambus was originally a member (although Rambus later withdrew). ${ }^{155}$ According to Infineon, Rambus's conduct violated JEDEC's rules, which required disclosure of both issued patents and pending patent applications. ${ }^{156}$ The district court dismissed Infineon's antitrust claims after trial on the grounds that Infineon had not proven the relevant geographic market Rambus was allegedly attempting to monopolize. ${ }^{157}$ Nonetheless, it upheld a jury verdict that Rambus had defrauded Infineon and JEDEC by failing to disclose its patent applications. ${ }^{158}$ The FTC apparently has investigated Unocal for similar conduct, ${ }^{159}$ and recently filed a complaint against Rambus. ${ }^{160}$

151. Dell Computer, No. 931-0097.

152. Whether Dell in fact knew this is a matter of some dispute. In her dissent to the FTC's proposed consent decree, Commissioner Azcuenaga claimed that there was "no evidence to support such a finding of intentional conduct." Id. (Azcuenaga, Comm., dissenting). Nonetheless, the FTC's findings suggested that Dell's content was at least knowing, if not intentional.

153. See id. n.13.

154. Rambus, Inc. v. Infineon Techs. AG, 164 F. Supp. 2d 743 (E.D. Va. 2001). For a discussion of the facts of the case, see Richard H. Stern, Rambus v. Infineon: The Superior Aptness of CommonLaw Remedies than Antitrust for Standardization Skullduggery, 2001 EUR. INTELL. PROP. REv. 495.

155. Rambus nonetheless kept abreast of JEDEC's standards decisions even after it withdrew from the SSO, and arguably tailored its patent applications during prosecution to match those standards. See $i d$. at 495. Cf. David A. Balto \& Daniel 1. Prywes, Standard-Setting Disputes: The Need for FTC Guidelines 3 (2002) (draft working paper, on file with author) (suggesting that the FTC mandate disclosure of any patent applications derived in part from information gained in a standard-setting process).

156. In fact, JEDEC's rule was changed in 1993 to explicitly address pending applications, but the court found that JEDEC members knew even before 1993 that the policy was intended to cover pending applications as well as issued patents. Rambus, 164 F. Supp. 2d at 743. See also Sandisk Corp. v. Lexar Media, No. C-98-01115, slip op. at 3 (N.D. Cal. Oct. 17, 2000) (holding that a claim of implied duty to disclose pending patent applications survived summary judgment).

157. Rambus, 164 F. Supp. 2d at 670.

158. Id.

159. Neela Banerjee, FTC Begins Inquiry into Unocal's Patents, N.Y TIMES, Aug. 15, 2001, available at http://www.nytimes.com/2001/08/15/business/15GAS.html?searchpv=day06 (discussing Unocal investigation); Alexei Barrioneuvo, Exhausting Feud: A Patent Fracas Pits Unocal Corp. Against Big U.S. Oil Producers, Wall St. J., Aug. 17, 2000, at 1; Tony Smith, Federal Trade Commission Probes Rambus, Sun, THE REG., Oct. 9, 2001, at http://www.theregister.co.uk/ 
A number of commentators have been critical of the FTC's consent decree in Dell Computer. Some of these complaints reflect concerns that the case might be read broadly as imposing liability on IP owners in the absence of proof of intent and ability to monopolize a market. ${ }^{161}$ These concerns are reasonable, and I discuss the proper elements of such a claim in detail below. But others have suggested that antitrust law should not police disclosures to SSOs at all. ${ }^{162}$ This absolutist approach strikes me as misguided. It is certainly feasible for an IP owner to gain a market advantage by concealing its IP rights from an SSO long enough for the SSO to adopt a standard. And where adoption of the standard is likely to determine the way the market develops, one wielding the power to control that standard may ultimately control the market. This is an antitrust risk that needs to be addressed. ${ }^{163}$

At least one court has dealt with an antitrust claim based not on failure to disclose a patent, but on a false representation of willingness to license the patent on reasonable and nondiscriminatory terms. In ESS Tech v. PC$\mathrm{Tel},{ }^{164}$ the district court held that a false representation to an SSO that a patent owner was willing to license on reasonable terms constituted more than a mere refusal to license, and was the sort of deceptive conduct that could support an antitrust claim. ${ }^{165}$ ESS has parallels to Dell Computer and Rambus; the only significant difference is that the patentee misrepresented its willingness to license a patent rather than the existence of the patent itself.

content/archive/21581.html. The FTC recently concluded a similar inquiry against Sun Microsystems without filing charges. Jayne O'Donnell, Rambus Faces Antitrust Lawsuit, USA TODAY, May 13, 2002, at http://www.usatoday.com/money/tech/2002-05-13-rambus.htm.

160. FTC Complaint, In re Rambus, Inc., No. 9302 (F.T.C. June 19, 2002); O'Donnell, supra note 159.

161. See, e.g., Teague 1. Donahey, Terminal Railroad Revisited: Using the Essential Facilities Doctrine to Ensure Accessibility to Internet Software Standards, 25 AIPLA Q.J. 277, 322-23 (1997); B. Zorina Kahn, Federal Antitrust Agencies and Public Policy Towards Antitrust and Intellectual Property, 9 CoRnell J.L. \& PuB. PoL'Y 133 (1999); Schallop, supra note 11, at 233 (calling the decision "infamous"); Schneck, supra note 100, at 656-57. For a somewhat more favorable treatment, see Gates, supra note 11, at 624; Dana R. Wagner, The Keepers of the Gates: Intellectual Property, Antitrust, and the Regulatory Implications of Systems Technology, 51 HASTINGS L.J. 1073, 1087-89 (2000).

162. Cf. Townshend v. Rockwell lnt'l Corp., 55 U.S.P.Q.2d 1011, 1026 (N.D. Cal. 2000) (rejecting an antitrust claim based on an IP owner's alleged fraud before an SSO, reasoning that "because a patent owner has the legal right to refuse to license his or her patent on any terms, the existence of a predicate condition to a license agreement cannot state an antitrust violation"). The court's legal syllogism is inaccurate, as we explained in 1 HovENKAMP ET AL., supra note $81, \S 13.4 \mathrm{~b}$. Suffice it to say that in antitrust, the power not to license at all does not automatically confer the power to impose whatever conditions one wishes on a license.

163. See CARLTON \& GeRTNER, supra note, 40 at 3 ("[C]ompanies that subvert cooperative standard setting processes to create their own proprietary, closed systems should face severe penalties.").

164. No. C-99-20292 (N.D. Cal. Nov. 2, 1999).

165. Id. at 3 . 
Misrepresentations can constitute anticoinpetitive conduct in appropriate circumstances, though by no means do all or even most misrepresentations by a competitor raise antitrust concerns. ${ }^{166}$ In the standard-setting context, the theory is that the IP owner's misrepresentation has manipulated the standard-setting process in a way that helps the IP owner achieve market power. Not only does the IP owner end up with exclusive control over the market standard, converting a group standard-setting process into a de facto one, but it uses the group standard to achieve a dominant position it might not have attained in an open standards competition. Had Rambus or Dell, for example, announced up front that the standards they were backing were proprietary, it is unlikely that the affected industries would have chosen those standards. At the very least, those standards would have faced stiffer competition within the SSO than they did. Put more formally, the competitive risk is that the misrepresentation will cause an SSO to adopt a standard it otherwise would have rejected, and that the adoption of that standard will in turn confer on the defendant market power it would not otherwise have obtained. This is a rather long chain of inferences, and each step im the chain should be elaborated.

First, an antitrust plaintiff must establish that the SSO would not have adopted the standard in question but for the misrepresentation or omission. This causation requirement is needed because the failure to disclose the existence of IP to an SSO will not affect the competitive marketplace if the SSO would have approved the standard if it had known about the IP right. For those SSOs with no IP policy or disclosure requirement, misrepresentation should not raise competitive concerns. Even if it violates some other duty, the misrepresentation did not cause the adoption of the standard, and therefore presumably did not contribute to or create market power. Indeed, in the absence of any affirmative requirement by the SSO that a party disclose its IP rights, it probably doesn't even make sense to speak of a failure to disclose as a "misrepresentation" at all. ${ }^{167}$

A separate issue is raised by SSOs that, notwithstanding their stated policy, have a history of promulgating standards even when they are aware that a company owns IP rights in the standard. In that case, the misrepresentation has not necessarily caused the adoption of the standard. Given the SSO's willingness to consider proprietary standards, it is possible that the orgamization would have adopted the proposed standard even if its members knew about the patent rights. Nonetheless, it is also possible that the SSO would have decided differently had its members been aware of the

166. For a discussion of misrepresentation as anticompetitive conduct, see 3A PHILIP E. AREEDA \& HERBERT HOVENKAMP, ANTITRUST LaI, $\uparrow 782 \mathrm{~b}$ ( $2 \mathrm{~d}$ ed. 2000).

167. It is possible, however, that a false affirmative statement could create liability even in such an SSO. For example, if a patent owner were to falsely claim to own no IP rights governing a proposed standard, such a statement could be the basis for an antitrust claim if SSO members relied on it in deciding to adopt the standard, even if the SSO had no explicit policy requiring disclosure. 
patent. This is particularly true for an SSO like the ATM Forum, which requires supermajority approval of patented standards. ${ }^{168}$ The first step in the causation chain requires factual inquiry in such a case. In other cases proof of but-for causation will be easier. If an SSO flatly refuses to adopt any standard covered by an IP right, for example, as some open source groups do, it should be apparent that an intentional failure to disclose the existence of an IP right affected the outcome of the decision.

Second, the SSO's decision to adopt the standard must in turn influence the market. Not all or even most standards adopted through an SSO dominate a relevant market. ${ }^{169}$ In only a limited number of cases will a standard achieve market dominance or the "dangerous probability" of successful monopolization needed to sustain an attempted monopolization claim under section 2 of the Sherman Act. Efforts to capture an industry standard will likely constitute anticompetitive conduct precisely where those efforts are likely to threaten monopolization-where the standard being set is likely to dominate the industry. ${ }^{170}$ Even there, monopolization must result from the misrepresentation and not merely from owning the IP right itself. Market dominance will be the necessary result of enforcing a patent on the standard only in those few cases where the patent actually confers an economic monopoly. In those cases in which there is no realistic alternative to infringing the patent, any misrepresentation to the SSO is likely irrelevant; it is the patent itself that confers power. Antitrust is more properly concerned with cases where the IP owner's control over the market stems from a failure of information in the market, a failure which the IP owner has induced. ${ }^{171}$ Market control is most likely when the SSO members collectively have a dominant share of the market, when past standards the SSO has promulgated have dominated the market, when standard setting is exclusive (that is, only one standard can be selected), and when the IP owner is unwilling to license the undisclosed IP on reasonable and

168. See infra Appendix.

169. See 2 HovENKAMP ET AL., supra note $34, \S 35.4(a)(2)$.

170. While such a market power determination is necessarily fact specific, the same can be said of any attempted monopolization case. Factors such as the collective market share of members of the SSO or the past success of group standards may be evidence of likelihood of successful monopolization.

By contrast, consider the situation in which an IP owner merely encourages the adoption of its standard by an independent agency, without any misrepresentations or intent to deceive. Absent such conduct, benefiting from a SSO's decision does not create a section 2 case.

171. In this sense, one might think of an IP owner who fails to disclose the IP to an SSO as in a position analogous to the defendant in Eastman Kodak Co. v. Image Technical Servs., 504 U.S. 451 (1992), where the defendant took advantage of buyers' imperfect information to require those who had bought copiers from it to purchase parts and service only from it. Where information is imperfect, markets based on that information will be imperfect also. Those in possession of the information can use their knowledge to disadvantage their competitors or consumers. See Mark R. Patterson, Product Definition, Product Information, and Market Power: Kodak in Perspective, 73 N.C. L. Rev. 185 (1994). 
nondiscriminatory terms. ${ }^{172}$ In the absence of some of these conditions, even if the IP owner's nondisclosure convimces the SSO to accept the proposed standard, the promulgation of that standard is less likely to affect competition. ${ }^{173}$

Even if the standard does achieve market power, that power must be attributable at least in substantial part to the actions of the SSO. If a standard would have become dominant anyway in a de facto standards competition, its adoption by the SSO, and thus the IP owner's misrepresentation, has not caused the market dominance. ${ }^{174}$ For example, if the IP right actually confers an economic monopoly because of the absence of feasible noninfringing alternatives, it is the IP right itself, not the IP owner's failure to disclose it to the SSO, that restricts competition in the market.

Finally, assuming an antitrust plaintiff can prove both market power (or a dangerous probability of its acquisition) and anticompetitive conduct that helped acquire or maintain that power, the plaintiff must prove that the defendant's failure to disclose its relevant IP rights was intentional and not an oversight. One might argue that failure to disclose is problematic regardless of intent. While that argument may have some force when it comes to contract and perhaps even IP law, antitrust law properly requires more. For an IP owner to violate the antitrust laws and be subject to treble damages, the law requires willful conduct in an effort to monopolize. Inadvertence does not suffice. ${ }^{175}$

Actual intent to monopolize is difficult to prove, but in some cases it can be inferred from conduct. ${ }^{176}$ This imference might be drawn from facts that suggest knowledge of a misrepresentation regarding IP was likely-for instance, where the inventor of the patent is also the person who signed a statement to the SSO. One might also draw an inference of at least reckless indifference from an IP owner's failure to do any investigation, particularly in that small subset of SSOs that impose an obligation to search one's own patent portfolio. In many standard-setting cases, such an inference will be easy to draw. In Allied Tube \& Conduit Corp. v. Indian Head, Inc., ${ }^{177}$ for example, the defendant successfully persuaded the National Fire Protection Association ("NFPA") not to certify polyvinyl conduit as fire-safe

172. See 2 HovenKAMP ET AL., supra note $34, \S 35.5(\mathrm{~b})$.

173. Because of this requirement, nondisclosure is more likely to violate the antitrust laws where interface standards rather than quality or safety standards are at stake. Quality and safety standards are normally nonexclusive, while the selection of an interface standard is more likely to exclude other possible interface protocols. Further, interface standards tend to exist in markets with network effects, and market power is more likely in such an industry.

174. On the difficulty of proving causation in the innovation context, see David McGowan, Innovation, Uncertainty, and Stability in Antitrust Law, 16 BERKELEY TECH. L.J. 729 (2001).

175. See Spectrum Sports, Inc. v. McQuillen, 506 U.S. 447, 456 (1993).

176. See, e.g., Handgards, Inc. v. Ethicon, Inc., 743 F.2d 1282, 1293 (9th Cir. 1984); William Inglis \& Sons Baking Co. v. ITT Cont'1 Baking Co., 668 F.2d 1014, 1027-28 (9th Cir. 1981).

177. 486 U.S. 492 (1988). 
insulation by recruiting new "members" of the NFPA, flying them to the meeting, and instructing them to vote down the proposal. The court found this conduct clearly was designed to influence the standard-setting process. ${ }^{178}$

A court should not be too quick to draw an inference of intent, however, because in many cases deciding whether a patent covers a particular standard will require an individual to construe the meaning of the patent claims. Patent claim construction is a complex and uncertain legal inquiry, ${ }^{179}$ and courts should be hesitant to impute knowledge of a patent's scope if there is evidence that the defendant believed in good faith that the patent that would not cover the standard. ${ }^{180}$ By contrast, where the evidence is indicative of bad faith, courts should be inore willing to infer intent. For instance, based on the facts found by the court in Rambus, it appears that Rambus entered into a course of conduct designed to deceive JEDEC about what patents and pending applications it owned. ${ }^{181}$ Similar courses of conduct constitute evidence from which a court can infer intent to monopolize. A court might also infer intent from truthful but misleading conduct, such as failing to fill out the form required by the SSO to affirm that all IP rights have been disclosed.

Once the above requirements for an antitrust violation through willful failure to disclose have been met, the question becomes whether an IP owner can avoid the disclosure obligation by withdrawing from the SSO. ${ }^{182}$ At the outset, it is relatively easy to dismiss some efforts to evade the SSO IP rules. For example, a company should not be permitted to resign from an SSO the day before the vote and rejoin the day after. Permitting such behavior would inake a inockery of the disclosure requirement.

178. Id.

179. See Markman v. Westview Instruments, 517 U.S. 370 (1996). For a discussion of the many problems that eome up in this context, see, for example, Craig Allen Nard, $A$ Theory of Claim Interpretation, 14 HARV. J.L. \& TECH. 1 (2000). Indeed, the effort to map the words of patent claims to products is inherently an uncertain one.

180. Cf. Mitek Surgical Prods. v. Arthrex, Inc., 230 F.3d 1383 (Fed. Cir. 2000) (finding suit not objectively baseless where alternative patent claim constructions were both plausible). A defendant will be able to make this argument in only a very limited number of cases. By hypothesis, the defendant is asserting in litigation that the patent does cover the standard. Thus, only where the defendant can prove that it legitimately believed one thing but now legitimately believes the opposite will this issue be relevant. It is worth noting, however, that in Rambus, the court ultimately concluded both that Rambus's patent infringement claim was frivolous-that Rambus's patent clearly did not cover the JEDEC standard-and that Rambus committed fraud by intentionally failing to disclose the patent to JEDEC. Rambus, Inc. v. Infineon Techs. AG, I64 F. Supp. 2d 743, 776-77 (E.D. Va. 200I). These findings are in some tension, since if the patent clearly doesn't cover the standard, Rambus should have no obligation to disclose it to JEDEC. Rambus was unsuccessful in pressing that argument, however, likely because it was claiming that the patent covered the standard.

181. Rambus, 164 F. Supp. 2d at 743.

182. Withdrawal is more likely as part of an effort to avoid reasonable and nondiscriminatory licensing obligations, rather than disclosure obligations. I discuss the consequences of withdrawal for licensing obligations in more detail supra Part III.A.2. 
A more serious question is presented when an IP owner decides to withdraw from an SSO altogether rather than disclose its IP interest in a pending standard. Here it is the timing of the withdrawal that is critical. Obviously a company that once belonged to an SSO isn't forever bound to disclose its IP rights to the SSO. At the same time, IP rights that already existed (or for which applications were pending) while the company was a member of the SSO and which cover standards under consideration while the company was a member should generally be understood to fall within the disclosure obligation. A company that strategically withdraws from an SSO to avoid disclosure may create the same sorts of problems that nondisclosure creates, although sometimes the act of withdrawal itself will serve to draw attention to the company's IP portfolio.

The above requirements are fairly stringent. As a result, antitrust liability for failure to disclose will likely be limited to those situations im which nondisclosure both is motivated by a desire to capture market share and is likely to do so. This is probably as it should be. Antitrust is an extreme remedy, and it is properly reserved for cases in which an IP owner's failure to disclose has significant competitive consequences. Thus, while antitrust can serve as a useful check on abuses of the standard-setting process, it cannot substitute for a general enforcement regime for disclosure rules. ${ }^{183}$

\section{Common Law Alternatives to Antitrust}

It is possible that the failure to comply with an SSO bylaw that restricts enforceability of IP rights could constitute fraud or misrepresentation. Fraud is most likely where, as in Dell Computer discussed in the last Section, the IP owner has an obligation to disclose the existence of an IP right and knowingly fails to do so or affirmatively states that none exists. A fraud theory might be a stronger enforcement mechanism for the SSO than contract, in that it offers plaintiffs the possibility of recovering their actual damages. And it may be a less cumbersome tool than an antitrust claim, which requires extensive inquiry into market definition and market power. Further, fraud may reach beyond antitrust law, since members of an SSO could be defrauded to their detriment even in circumstances in which it is unlikely the IP owner could exercise control over a relevant economic market. ${ }^{184}$ The Rambus case discussed above was ultimately decided on fraud and not antitrust grounds, for example. ${ }^{185}$

183. I therefore disagree with Wagner, who argues that Dell Computer reflects an implicit shift from a property rule towards a general liability rule in standard setting. See Wagner, supra note 161, at 1089-93.

184. See Stern, supra note 154 , at 495 (discussing the relative merits of fraud and antitrust claims in this situation).

185. Rambus, 164 F. Supp. $2 d$ at 743. 
But there are limitations on the use of fraud as a substitute for antitrust. Most notably, a fraud theory premised on nondisclosure must necessarily be based on some duty to the plaintiff, which would seem to preclude suits by consumers or by nonmembers of the SSO. ${ }^{186}$ Thus, while a fraud theory offers an affirmative basis for relief, it is subject to some of the same problems as a breach of contract claim.

Janice Mueller has recently suggested another alternative: applying the patent misuse doctrine to preclude enforcement of patents that an IP owner willfully failed to disclose to an SSO. ${ }^{187}$ Using misuse doctrine has some advantages, most notably avoiding the more ponderous machinery of antitrust, ${ }^{188}$ but misuse has problems as well. First, it isn't clear how a misuse claim would fare under existing law. The Patent Misuse Reform Act provides that refusal to license a patent cannot constitute misuse. ${ }^{189}$ There may be ways around this. For example, the bad conduct might be the misleading silence, rather than simply the refusal to license. However, the Federal Circuit is likely to be skeptical of misuse claims that it perceives to be based on a unilateral refusal to license. ${ }^{190}$ Second, the Federal Circuit's current formulation of patent misuse-whether it expands the patent beyond its lawful scope-doesn't seem applicable to a failure to disclose a patent. ${ }^{191}$ Finally, the remedy for patent misuse-a judicial refusal to enforce the patent at all until the misuse is purged ${ }^{192}$-may be overbroad in circumstances in which the patent also covers technologies not included in the standard.

\section{Conclusions}

SSO IP rules are enforced through a hodgepodge of legal theories, each with their own shortcomings. Taken together, these legal rules do a fair job of ensuring that IP owners do what they promised to do. In this Part I have suggested some ways that the law should be interpreted to improve enforcement in circumstances in which it is warranted. But the

186. See State ex rel. The Illuminating Co. v. Cuyahoga Cty. Ct. of Common Pleas, 776 N.E.2d 92 (Ohio Ct. App. 2002) (listing the elements of a common law fraud claim, including the existence of a duty to disclose).

187. Mueller, Misuse, supra note 8. See also Cowie \& Lavelle, supra note 11, at 114-18.

188. Because misuse is a defense to patent infringement, it does not require proof of market definition, damages, standing, and various other requirements that make antitrust litigation so protracted and expensive. On differences between patent misuse and antitust law, see 1 HoveNKaMP ET AL., supra note 81, § 3.2(c); Mark A. Lemley, Comment, The Economic Irrationality of the Patent Misuse Doctrine, 78 CALIF. L. Rev. 1599 (1990).

I89. 35 U.S.C. \$ 271(d)(4) (2000).

190. Cf. C.R. Bard, Inc. v. M3 Sys., Inc., I57 F.3d 1340, I373 (Fed. Cir. 1998) ("[T]he catalog of practices labeled 'patent misuse' does not include a general notion of 'wrongful' use.").

I91. See B. Braun Med., Inc. v. Abbott Labs., 124 F.3d I419 (Fed. Cir. I997). For criticism of this requirement, see Cowie \& Lavelle, supra note 11, at I16-17.

192. See Morton Salt Co. v. G.S. Suppiger \& Co., 314 U.S. 488 (1942); 1 HovenKamP ET AL., supra note $81, \S 3.6(a)$. 
bottom line is that the law provides various effective means to enforce SSO IP rules.

\section{IV}

\section{ANTITRUST LIMITS ON STANDARD-SETTING ORGANIZATION INTELlectual Property Rules ${ }^{193}$}

SSO rules regarding the ownership of IP present a number of antitrust issues. In Part III.C, I considered the possible antitrust liability of an IP owner for violating an SSO's rules by failing to disclose or refusing to license a patent covering a standard. In this Part, I will focus on the possible liability of the SSO and its members for collaborating to compel a license from an IP owner. These antitrust theories are in soine sense mirror images; one assumes that the SSO IP rule is procompetitive and punishes efforts to avoid it, while the other views the rule itself as anticompetitive because it reduces incentives to innovate. After reviewing the rather underdeveloped state of the law in this area, I conclude that antitrust law should show great deference to legitimate efforts to set collective rules for dealing with IP, even if those rules require competitors to discuss both the technical merits of their products and the price of an IP license.

The deference I suggest is specific to IP rules. I do not mean to suggest that SSOs should generally be immune from antitrust scrutiny. SSOs face antitrust scrutiny on a variety of grounds unrelated to the IP rules they adopt. For example, some cases have suggested that SSOs themselves may violate section 1 of the Sherman Act as a cartel. ${ }^{194}$ Other cases challenge efforts to exclude certain competitors from using the standard set by an SSO or from participating in the SSO altogether. ${ }^{195}$ A large number of cases challenge the selection of a standard itself on the merits; ${ }^{196}$ still others challenge the process by which the standard was selected. ${ }^{197}$ There are also cases that focus on the special problems of immunity associated with government-set standards, ${ }^{198}$ and the liability of the SSO for the acts of its members. ${ }^{199}$ I have discussed these issues in detail elsewhere, ${ }^{200}$ and I do not revisit them here except to the extent they relate directly to SSO IP rules.

193. Portions of this Part have been republished in adapted form in 2 HovenKaMP ET AL., supra note 34.

194. See, e.g., Addamax Corp. v. Open Software Found., 888 F. Supp. 274, 281, 284-85 (D. Mass. 1995), aff d, 152 F.3d 48 (1st Cir. 1998) (finding that an antitrust challenge to an SSO could proceed to trial under the rule of reason, but ultimately finding no liability). For a discussion of these cases, see 2 HOVENKAMP ET AL., supra note $34, \$ 35.2$.

195. For a discussion of these cases, see 2 HovenKAMP ET AL., supra note $34, \S 35.3$.

196. For a discussion of these cases, see id. $\$ 35.4$.

197. See id. \$35.5.

198. See id. $\$ 35.7$.

199. See id. \$35.8.

200. See id. \$35; see also Lemley, Internet Standardization, supra note 11. 


\section{A. Intellectual Property as Procompetitive}

The typical antitrust analysis of IP and standard setting assumes that the existence and enforcement of IP rights poses a potential risk to competition. Courts inquire into whether an IP right confers market power, or alternatively whether that right has been used to restrict competition in an industry. This standard approach makes sense in light of the classical conception of the IP-antitrust conflict: that IP rights represent a necessary interference with an otherwise competitive market. ${ }^{201}$

There is an alternate way to think of the relationship between IP and antitrust, however. In industries in which continual innovation is important to social welfare, IP can be procompetitive on balance insofar as it encourages more innovation than it restrains. On this theory, interfering with the acquisition and enforcement of IP rights, while procompetitive in the short run, actually harms social welfare in the long run by reducing innovation. ${ }^{202}$ Examples of procompetitive uses of IP in the standard-setting context exist in industries in which standards evolve quickly. In several instances, an IP owner has used its IP rights to ensure that softwares that used a standard were interoperable, and to oppose efforts to "split" the standard.

One example of a company making such a use of IP rights is Sun's litigation against Microsoft over the compatibility of Sun's "Java" platform. The fundamental issue in the case concerned Microsoft's alleged alteration of certain aspects of the Java technology. Sun contended that Microsoft was attempting to co-opt the Java platform (which is "platform independent," meaning it runs on many different operating systems) by designing a separate, proprietary "version" of Java that runs only on Windows, and not on competing operating systems. Sun's concern was that a Windows-specific version of Java could undermine the potential transition to platform-independent competition; Microsoft claimed it

201. See generally 1 HovENKAMP ET AL., supra note $81, \S 1.3$. Among the voluminous literature on the overlap between IP and antitrust law, see Robert D. ANDERson \& NaNCY T. Gallini, Competition Policy and Intellectual Property Rights in the Knowledge-Based Economy (1998); Ward S. Bowman, Jr., Patent and ANTitrust LaW: A Legal and Economic Appraisal (1973); William Baxter, Legal Restrictions on Exploitation of the Patent Monopoly: An Economic Analysis, 76 Y ALE L.J. 267 (1966); Richard Buxbaum, Restrictions Inherent in the Patent Monopoly: A Comparative Critique, 113 U. PA. L. REv. 633 (1965); Louis Kaplow, The PatentAntitrust Intersection: A Reappraisal, 97 HaRv. L. Rev. 1813 (1984); Tracy R. Lewis \& Dennis Yao, Some Reflections on the Antitrust Treatment of Intellectual Property, 63 ANTITRUST L.J. 603 (1995); Willard K. Tom \& Josh A. Newberg, Antitrust and Intellectual Property: From Separate Spheres to Unified Field, 66 ANTITRUST L.J. 167 (1997).

202. This was the FTC's theory in the Intel consent decree, for example. In re Intel Corp., No. 9288 (F.T.C. 1999), available at http://www.ftc.gov/os/1999/9903/d09288intelagreement.htm. For a detailed discussion of the FTC's case against Intel, see 1 HovENKAMP ET AL., supra note 81, § 13.4(d). Other government cases premised on threats to future innovation include United States $v$. Microsoft Corp., 253 F.3d 34 (D.C. Cir. 2001) and United States v. Visa U.S.A., Inc., 163 F. Supp. 2d 322 (S.D.N.Y. 2001). 
altered the Java specifications to "optimize" Java's performance with Windows. ${ }^{203}$

This dispute raised some fundamental antitrust and IP issues. If Microsoft could alter the Java technology to disrupt its platform independence, it could short circuit the promise Java holds for operating-systems competition. ${ }^{204}$ Indeed, as long as Microsoft's version of Java works better with Windows than do other versions of Java, users might gravitate towards the Microsoft version. Microsoft's historical experience (its successful domination of numerous other markets ${ }^{205}$ ) might reasonably give it some confidence that by splitting the standard into incompatible, proprietary versions, it could engineer a de facto standards competition that it stands a good chance of winning. If Java were truly an open platform, owned by no one, it seems unlikely that Sun could prevent this. Sun's reservation of its IP rights in Java provided it with the means to prevent unauthorized alteration of the standard and therefore to preserve the integrity of a cross-platform standard that might otherwise be fragmented. ${ }^{206}$

With the possibility firmly in mind that in certain circumstances IP rights can promote rather than hinder competition, one might look at SSO rules that restrict ownership of IP in a new light. If IP is procompetitive, SSOs and their members might violate the antitrust laws by collectively attempting to defend against patent enforcement or compel licensing of those patents. Arguments of this sort arise in two contexts. First, SSOs sometimes act collectively to defend against lawsuits by nonmembers that claim that a standard infringes their patents. Second, the act of adopting SSO IP rules itself might be viewed as an effort to purchase advance licenses to a yet-to-be-determined group of patents at an artificially low price. I consider each argument in turn.

\section{B. Joint-Defense Agreements as Licensee Cartels}

It is well established in antitrust law that monopsony and buyers' cartels are just as pernicious to competition as monopoly and sellers' cartels. ${ }^{207}$ The risks mirror the risks from seller's cartels-prices will be artificially depressed rather than artificially raised. Legal treatment of monopsony likewise mirrors the treatment of monopoly. Thus, in National

203. Sun Microsystems, Inc. v. Microsoft Corp., 999 F. Supp. 1301, 1310 (N.D. Cal. 1998).

204. See id. (noting that Microsoft's argument in the case "would essentially allow Microsoft to destroy the cross-platform compatibility of the JAVA programming environment").

205. See, e.g., United States v. Microsoft Corp., 253 F.3d 34 (D.C. Cir. 2001) (holding that Microsoft has monopoly power in the operating systems market).

206. For a detailed discussion, see Lemley \& McGowan, supra note 40.

207. Monopsony is the exercise of market power by buyers rather than sellers to artificially depress prices. For detailed discussion, see Roger D. Blair \& JeFrrey L. HarRison, Monopsony: Antitrust Law And Economics (1993); 12 Herbert Hovenkamp, Antitrust Law ch. 20B (2d ed. 2000); Roger D. Blair \& Jeffrey L. Harrison, Cooperative Buying, Monopsony Power, and Antitrust Policy, 86 Nw. U. L. Rev. 331, 338 (1992). 
Macaroni Manufacturers Ass' $n$ v. FTC, ${ }^{208}$ the FTC challenged an agreement by members of a pasta manufacturers' trade association to set standards for the composition of the pasta they would sell. The Commission successfully argued that the standards were intended to artificially depress the price of durum wheat, a traditional pasta ingredient. The fact that the horizontal agreement injured sellers rather than buyers, and drove prices down rather than up, did not save it from per se condemnation.

When IP rights are at stake, SSOs sometimes act as a buyers' cartel (or more precisely, a licensee cartel). SSOs can serve as a sort of clearinghouse for the defense of infringement suits in which patents are asserted against an entire industry. They may agree to share costs or to jointly hire lawyers to opine on the validity of the patent. Joint-defense agreements also sometimes bind the members not to settle independently of the group as a whole. Because this sort of joint defense against IP owners involves concerted action by competitors, it raises many of the same economic concerns as a traditional cartel. By negotiating jointly, the meinbers of an industry may be able to obtain a license for a lower price than if they bargained individually. Indced, some early industry associations were apparently set up primarily to coerce lower licensing fees by preventing the inembers from settling patent infringement suits independently. ${ }^{209}$

Joint-defense agreements may have some procompetitive effects. They presumably generate substantial efficiencies resulting from reduced legal costs. Further, to the extent that society perceives enforcement of the IP right itself as undesirable-perhaps because the IP owner is holding up an industry that did not in fact benefit from its invention-SSO jointdefense agreements may be an effective response. There are unquestionably circumstances in which IP litigation is filed as part of a holdup, ${ }^{210}$ and a fair bit of academic literature suggests that "clearing" the thicket of overlapping IP rights may be necessary for true innovation to occur. ${ }^{211}$ In cases in which different parties hold patents on necessary inputs to a particular

208. 65 F.T.C. 583 (1964), enforced, 345 F.2d 421 (7th Cir. 1965).

209. See, e.g., Steven W. Usselman, Regulating Railroad Innovation: Business, TeCHNology, AND Politics IN AMERICA, I840-1920, at 171-76 (2001) (discussing the Eastern and Western Railroad Associations).

210. The most infamous "holdup" artist in IP cases was Jerome Lemelson, who enforced his hundreds of patents against companies in a wide variety of industries, but never himself made any products. For a discussion, see M. Scott Carey, Note, Ford Motor Co. v. Lemelson, 13 Berkeley TECH. L.J. 219 (1998).

211. Michael A. Heller \& Rebecca S. Eisenberg, Can Patents Deter Innovation? The Anticommons in Biomedical Research, 280 SCI. 698 (1998); Lemley, supra note 2; Robert P. Merges, Intellectual Property Rights and Bargaining Breakdown: The Case of Blocking Patents, 62 TENN. L. Rev. 75 (1994) [hereinafter Merges, Bargaining Breakdown]; Arti K. Rai, Fostering Cumulative Innovation in the Biopharmaceutical Industry: The Role of Patents and Antitrust, 16 BERKELEY TECH. L.J. 813 (2001); Shapiro, Thicket, supra note 11. 
standard, solving the double-marginalization problem can also be a substantial efficiency. ${ }^{212}$

Defense against an actual lawsuit is protected by Noerr-Pennington immunity unless the "petitions" (here, the defensive court filings) amount to a "sham." 113 The same is true of coordinated efforts to defend against a lawsuit. ${ }^{214}$ Thus, most such joint defense agreements will be immune from antitrust scrutiny so long as the defendants only share costs and information, and do not jointly exercise settlement authority. ${ }^{215}$ Immunity should also apply to joint petitions in the administrative context, as where the SSO submits evidence concerning a pending patent application or petitions the Patent and Trademark Office ("PTO") for reexamination. ${ }^{216}$

It is less clear, however, whether agreements that contemplate litigation or administrative action but do not actually involve petitions trigger Noerr-Pennington immunity. The Federal Circuit has indirectly suggested that agreements in advance of litigation to defend a competitor if they are sued for patent infringement aren't immune under Noerr-Pennington and may violate the antitrust laws. ${ }^{217}$ On the other hand, it is surely permissible to agree to indemnify a customer who is sued for patent infringement

212. The double-marginalization problem occurs when two monopolists own complementary inputs, and each prices at the monopoly level. The resulting systems price is inefficiently high. See infra note 268. Cf. Douglas Lichtman, Property Rights in Emerging Platform Technologies, $29 \mathrm{~J}$. LEGAL STUD. 615 (2000) (making a double-marginalization argument in favor of vertical integration in computer systems).

213. The Noerr-Pennington doctrine immunizes defendants from antitrust liability resulting from their efforts to petition government or the courts. It is based on the First Amendment right to petition. For detailed discussion of Noerr-Pennington immunity, see 1 AREEDA \& HovENKAMP, supra note 29, 99 201-08. On the question of whether concerted agreements qualify for Noer7-Pennington immunity, see id. $\{203 \mathrm{i}$; 12 HovenKAMP, supra note 207, $\{2044$.

214. See Lemelson v. Bendix Corp., 621 F. Supp. 1122 (D. Del. 1985) (holding that joint defense in a patent infringement suit is not an antitrust violation); 12 HovENKAMP, supra note 207, ๆ 2045; cf. In re Circuit Breaker Litig., 984 F. Supp. 1267 (C.D. Cal. 1997) (holding that joint suit by trademark plaintiffs is protected by Noerr-Pennington immunity).

In FTC v. Superior Ct. Trial Lawyers Ass' $n, 493$ U.S. 411 (1990), the Court held illegal per se and unprotected by Noerr-Pennington immunity a group boycott by lawyers who routinely worked as appointed counsel for indigent defendants. The lawyers were seeking to obtain a higher billable rate for the work. The reason the Superior Court Trial Lawyers Asscciation ("SCTLA") boycott did not qualify for the immunity may be that the government was the buyer in the market and was therefore the target of the boycott, rather than a decision-making body petitioned in its governmental capacity. Thus, SCTLA does not stand for the proposition that joint petitions lose immunity.

215. In Gould v. Control Laser Corp., 462 F. Supp. 685 (M.D. Fla. 1978), the court held that an agreement to share the costs of litigation against a patent was ordinarily legal, and "only in the most egregious circumstances would the Sherman Act proscribe such an agreement." Id. at 692. Accord Jones Knitting Corp. v. Morgan, 361 F.2d 451 (3d Cir. 1966) (condemning a joint defense agreement, but only because it went beyond the sharing of litigation costs and attempted to control the ability of the members to settle the case independently).

216. See 2 HoVENKAMP ET AL., supra note $34, \$ 11.2($ b).

217. See Rodime PLC v. Seagate Tech., Inc., 174 F.3d 1294 (Fed. Cir. 1999). In that case, the court merely opined that Noerr-Pennington immunity was unlikely and that the facts gave "rise to an inference" that the antitrust laws had been violated. Id. at 1307 . 
because they used a supplier's product. Efforts by an SSO to gather prior art in advance of anticipated litigation occupy a gray area in the law between these two positions. The better rule is to protect such ancillary activity, just as threats to file a lawsuit are protected in most circuits. ${ }^{218} \mathrm{~A}$ contrary rule, protecting only litigation filings but not licensing negotiations, would needlessly encourage litigation of disputes that might otherwise be settled before a case is ever filed.

Concerted decision making by defendants during litigation presents a somewhat different problem. Defendants with common interests who act jointly must retain independent decision-making authority. If they act in concert in deciding not just how to litigate the case, but whether to settle and on what grounds, they have crossed the line into a conspiracy to restrain trade. In Primetime 24 Joint Venture v. $N B C$, Inc., ${ }^{219}$ the Second Circuit held that a conspiracy between copyright owners not to settle (that is, deal) with an infringement defendant could violate section 1 of the Sherman Act. The court emphasized that "copyright holders may not agree to limit their individual freedom of action in licensing future rights to such an infringer." ${ }^{220}$ The same is true in the reverse situation as well-where a group of accused infringers jointly agrees not to settle with a plaintiff. ${ }^{221}$ This may put a law firm that represents multiple defendants in a difficult position, since it must advise each client independently and may not coordinate settlement strategies. Nonetheless, at least one court has rejected an antitrust claim based on joint decision making notwithstanding the fact that the same firm represented all the defendants. ${ }^{222}$

218. See 1 AREeda \& HovenKamp, supra note 29, II 503(e); Coastal States Mktg., Inc. v. Hunt, 694 F.2d 1358 (5th Cir. 1983) (threats to sue are protected by Noerr-Pennington immunity). But see Cardtoons, L.C. v. Major League Baseball Players Ass'n, 208 F.3d 885 (10th Cir. 2000) (en banc) (holding that threats to sue are unprotected by Noerr-Pennington immunity in a nonantitrust case). For further discussion of immunity for threats to sue, see 2 HovENKAMP ET AL., supra note $34, \S 11.3 \mathrm{~b} 5$.

219. 219 F.3d 92 (2d Cir. 2000).

220. Id. at 103.

221. See, e.g., Jones Knitting Corp. v. Morgan, 361 F.2d 451 (3d Cir. 1966) (holding such an agreement illegal per se); Sony Elecs., Inc. v. Soundview Techs., Inc., 157 F. Supp. 2d 172, 183 (D. Conn. 2001) (refusing to dismiss an antitrust complaint that alleged that members of an SSO had conspired to set a maximum price they would pay to license a patent); Gould v. Control Laser Corp., 462 F. Supp. 685, 69I-93 (M.D. Fla. 1978) (treating such an agreement under the rule of reason and granting summary judgment because plaintiffs offered no evidence that the joint defense agreement extended to agreement on the terms of settlement); cf. Shapiro v. Gen. Motors Corp., 472 F. Supp. 636, 641 (D. Md. 1979) (rejecting on summary judgment an antitrust claim based on auto makers' uniform insistence on royalty-free, second-source licenses; the court reasoned that the patentee had the option not to sell and therefore was not harmed).

222. Lemelson v. Bendix Corp., 621 F. Supp. 1122 (D. Del. 1985). 


\section{Standard-Setting Organization Rules Restricting Intellectual Property as Antitrust Violations}

A somewhat inore complex issue is presented by SSO rules regarding ownership or licensing of IP outside the litigation context. If IP rights are procompetitive because they encourage innovation, might an SSO violate the antitrust laws by requiring IP owners to limit or forfeit their rights as a condition of standardization? ${ }^{223}$ The SSO cannot take shelter under the Noerr-Pennington doctrine because making and enforcing bylaws does not relate directly to petitioning the government. ${ }^{224}$ The answer may depend on what the bylaws say.

\section{Disclosure Requirements}

To begin, consider an SSO (like VESA or ANSI) that requires disclosure of IP rights to the SSO before the SSO members vote on the standard but does not otherwise interfere with ownership. ${ }^{225}$ It seems nnlikely that such a disclosure requirement standing alone could be anticompetitive. Although the requirement has an information-forcing effect, and may in some unusual circumstances interfere with an IP owner's trade secret rights, ${ }^{226}$ this is unlikely to be a major concern. Only the existence and scope of the patent or patent application, not the technical know-how of the invention itself, normally must be disclosed to an SSO. While the very existence of a patent application may sometimes be a valuable secret, in the context of a publicly adopted standard the legitimate value of this particular secret does not seem very high. Further, withholding the information would be most valuable as a tool for deception, as in Dell Computer. ${ }^{227}$

The SSO, on the other hand, has a presumptively legitimate reason for requiring the information: it wishes to make a fully informed decision on whether to adopt a particular standard. SSOs should be given significant leeway to adopt reasonable rules that are necessary to the operation of their business, even if those rules indirectly regulate the circumstances under which competition occurs. Further, it is difficult to see how consumers will

223. For an argument that SSO IP rules are used to facilitate cartels, see Peter Grindley et al., Standards Wars: The Use of Standard Setting as a Means of Facilitating Cartels in Third Generation Wireless Telecontmunications Standard Setting, 3 INT'L J. CoMM. L. \& PoL'y 2 (Summer 1999).

224. This is true of private SSOs. For rules relating to petitioning government-run SSOs, see 2 HOVENKAMP ET AL., supra note $34, \S 35.7$.

225. See infra Appendix.

226. SSO rules that restrict ownership or require disclosure of IP normally apply to patents, which are necessarily public documents. Some SSOs extend the rule to pending patent applications, a logical move since they are worried about pending applications that will issue once the standard is adopted. Because some patent applications can also be trade secrets-specifically, those not embodied in a product sold on the open market, and which are in their first eighteen months of prosecution, or which are filed only in the United States (see 35 U.S.C. $\$ 122(2000)$ ) - it is possible that a disclosure rule will require a trade secret owner to disclose its secret to competitors.

227. See supra notes $149-53$ and accompanying text. 
be harmed by a disclosure requirement. Presumably the 1P owner is free to decide whether to submit its proposal for consideration as a standard, and the SSO is free to decide whether to adopt the standard notwithstanding the existence of the IP right.

A different type of challenge to an SSO disclosure rule might assert that the purpose of requiring disclosure is to permit the SSO to refuse to adopt any standard covered by an IP right. This is in effect a claim that the rule isn't really just a disclosure rule, but in fact is a no-IP rule. I discuss such rules below. ${ }^{228}$

\section{Royalty-Free or Compulsory Licensing Requiremcnts}

Where an SSO requires members to license their IP rights, either to other members or to all comers (as the ISO does $^{229}$ ), or where it requires members to forgo IP protection for a standard altogether (as the IETF used to $\left.\mathrm{do}^{230}\right)$, more difficult questions are presented. The fundamental right granted to IP owners is the right to exclude others; forcing them to give up that right restricts the value they can get from their IP. Further, while some variants on the compulsory-licensing rule permit the IP owner to set the royalty rate, so long as it isn't discriminatory, others restrict the royalty that can be charged or require IP owners to forgo a royalty altogether. ${ }^{231}$ Such rules may reduce the incentive to develop potential new standards or the incentive to participate in cooperative standard setting rather than "going it alone" in a de-facto standards competition. Both the Antitrust Division of the U.S. Department of Justice ("DOJ") and the FTC have taken the position in individual cases that an SSO rule that prohibits members from owning IP rights in a standard may violate the antitrust laws. ${ }^{232}$

228. See infra Part IV.C.2.

229. See infra Appendix.

230. See supra note 7.

231. It isn't clear into which category we should put a requirement that the IP owner license its patent on "reasonable" terms. If the reasonableness requirement has teeth, it may permit or even require SSO oversight of the rate charged. If, on the other hand, it is largely precatory, the IP owner has much more freedom.

232. In a series of negotiations regarding rules promulgated by ETSI, the United States put substantial pressure on ETSI to back down from its original rule requiring disclosure and nondiscriminatory licensing of member IP rights embodied in ETSI standards. See, e.g., Amy A. Marasco, Standards-Setting Practices: Competition, Innovation and Consumer Welfare, Testimony before the Federal Trade Commission and U.S. Department of Justice (April 18, 2002). This approach has precedent in some earlier U.S. cases condemning patent pools and cross licenses. See, e.g., United States v. New Wrinkle, Inc., 342 U.S. 371 (I952). Further, there were apparently some legitimate complaints about the reciprocity of the ETSl licensing provisions. See Corien Prins \& Martin Schiessl, The New Telecommunications Standards Institute Policy: Conflicts Between Standardisation and Intellectual Property Rights, 8 Eur. INTELL. Prop. Rev. 263 (1993). For discussions of the evolving ETS1 rule on IP rights, see Raymond T. Nimmer, Standards, Antitrust and Intellectual Property, in InTEllectual Property ANTITRUST (P.L.I. 1995); Bekkers \& Liotard, supra note 96, at 122; Mark Shurmer \& Gary Lea, Telecommunications Standardization and Intellectnal Property Rights: A 
And at least one court has found that an antitrust claim alleging that an SSO conspired to demand a low "reasonable" royalty rate survived a motion to dismiss. ${ }^{233}$

In evaluating such a claim, several mitigating circumstances and potential justifications should be taken into account. First, because an SSO rule should be treated under the rule of reason, rather than the per se rule, a court must inquire into market conditions before condemning an IP policy. ${ }^{234}$ SSOs whose members don't collectively have market power will find it difficult to influence the market in a way that restricts mnovation, even if that is their goal.

Second, courts should not forget the alternatives available to members. Companies that do not want to relinquish rights im their IP have a choice: they can decline to participate in the SSO altogether, or they can withdraw from consideration of a particular standard $\mathrm{m}$ which they have an niterest. ${ }^{235}$ Because SSO rules necessarily bind only members of the SSO, exit is always an option. The only companies for whom this will not be a realistic choice are the ones whose goal is to push for group adoption of a standard to which they own the rights. But there is no reason such companies should have it both ways. If the SSO permits licensing on reasonable and nondiscriminatory terms, IP owners do not need to retain any further rights unless their true goal is to hold up members after the standard is adopted. Even if the SSO requires royalty-free licensing, the option of exit is not terribly onerous. If the intrinsic value of the proposed standard is great enough, the SSO may adopt it anyway-or if the SSO won't, the market may.

Finally, a rule requiring the licensing of IP may actually be more efficient than the alternative. If membership in an SSO is symmetrical-if it isn't dommated by a single company and if members are on average equally likely to own IP rights in a proposed standard-the SSO does not really have the structure of a buyers' cartel. Instead, the IP policy serves a

Fundamental Dilemma?, in Standards POLICY FOR INFORMation INFRASTructure 378, 392-96 (Brian Kahin \& Janet Abbate eds., 1995).

In In re American Society of Sanitary Engineering, 106 F.T.C. 324, 329 (1985), the FTC entered into a consent decree with the American Society of Sanitary Engineering ("ASSE") that forbade it from rejecting proposed standards solely on the grounds that they were patented. The underlying FTC complaint had alleged that the ASSE policy "had no reasonable basis or justification" and amounted to a concerted refusal to deal. Id. 1t is significant that the standard in question in this case involved health and safety and was inclusive rather than exclusive, so that allowing the complaining party's product to be included in the standard would not have restricted the rights of other members to make use of other approved technologies.

233. Sony Elecs., lnc. v. Soundview Techs., Inc., 157 F. Supp. 2d 172, 183 (D. Conn. 2001).

234. See Lemley, Internet Standardization, supra note 11, at 1080-81 (arguing for treatment under the rule of reason).

235. This assumes that such a withdrawal will he effective in avoiding a licensing obligation. On this point, see supra Part 1II.A.2. 
purpose analogous to a cross-licensing scheme between blocking patents. ${ }^{236}$ Particularly when different parties may lay claim to the same standard, a licensing requirement expands competition by insuring that all members of the SSO are free to build products incorporating that standard. This clearing of the "patent thicket"237 is particularly important to standardization efforts in industries like semiconductors, where tens of thousands of patents would, if enforced, make product development all but impossible. ${ }^{238}$ There is substantial disagreement among both scholars and businesspeople about whether open or proprietary standards best promote innovation in any given case. ${ }^{239}$ Courts should leave substantial room for SSOs to decide that an open standard will best promote their collective interests in the context of a particular market.

Further, since the SSO bylaw is adopted ex ante, the SSO members can enter into the agreement not knowing whether they will be the IP licensor or licensee in any given case. When companies who voluntarily agree to license IP on reasonable and nondiscriminatory terms are operating under a veil of ignorance ${ }^{240}$ - that is, when they don't know whether the rule will help or harm them-they may be presumed to do so because they believe the licensing requirement to be the best policy for the SSO as a whole. There is typically no reason to believe that the goal of such a bylaw is to discriminate against one particular IP owner. ${ }^{241}$

The result is that, subject to two caveats, SSO rules that restrict the exercise of IP rights in a standard should generally be permissible, ${ }^{242}$ especially when they serve to clear potentially competing claims on a standard. One caveat concerns SSO rules that require licensing, but only to other members of the SSO. In certain circumstances, SSO rules that privilege members over nonmeinbers can have the effect of raising rivals' costs or

236. See 2 HovenKAMP ET AL., supra note 34, at ch. 34 (discussing blocking patents and crosslicensing).

237. See Shapiro, Thicket, supra note 11.

238. See, e.g., Heller \& Eisenberg, supra note 211 (discussing the problem of "anticommons" property).

239. For a detailed discussion, see Weiser, Networks Unplugged, supra note 35. See also Lemley, Internet Standardization, supra note 11; Farrell, Choosing, supra note 37.

240. Cf. JoHN RAwLS, A THEORY OF Justice 11 (rev. ed. 1999) (asserting that societies are more likely to make just decisions under a veil of ignorance). For an extended application of Rawls's theory of intergenerational justice under the veil of ignorance to IP law, see Dawn C. Nunziato, Justice Between Authors, 9 J. INTELL. Prop. L. 219 (2002).

241. Of course, in any given case the evidence may demonstrate that the goal was to discriminate. Where an SSO adopts a new IP-restrictive rule over the dissenting vote of an IP owner, with the intention of depriving the IP owner of his rights, antitrust law might be more concerned.

242. In one case Congress has expressly endorsed such a rule. See 17 U.S.C. $\$ 512(i)(2)(B)$ (2000) (defining a "standard technical measure" as one adopted by an SSO and which is "available to any person on reasonable and nondiscriminatory terms"). 
even of excluding them entirely, and therefore cartelizing the industry. ${ }^{243}$ This should not be a problein, however, unless membership in the SSO is closed, the number of members is relatively small, and the members collectively control a significant share of the market. In those circumstances, the SSO may create antitrust problems. ${ }^{244}$

The second caveat covers SSOs that seek not only to specify that licensing will occur on reasonable and nondiscriminatory terms, but also to cap the total fees that will be paid to license all patents. At least one SSO is attempting to do precisely this in $3 \mathrm{G}$ mobile telephony. ${ }^{245}$ Capping the total price to be paid to all IP owners may create monopsony problems because it depresses the total price to be charged for innovation. Those monopsony problems aren't necessarily debilitating, but they are serious enough that SSOs should be concerned about the antitrust consequences of adopting such an approach. This does not mean that members of the SSO should be prohibited from discussing price. Finding out what a "reasonable and nondiscriminatory" license will actually cost will help determine the true value of a proposed standard and how it compares to possible alternatives. It is only when the SSO tries to cap the price ex ante that significant antitrust issues arise.

\section{Conclusions}

SSOs must recognize that they are built on agreements among horizontal competitors, and that their conduct will be subject to scrutiny under section 1 of the Sherman Act. But antitrust courts should recognize that SSOs serve valuable procompetitive purposes, and that they will not be able to function effectively if subject to unreasonable risk of antitrust liability. ${ }^{246}$ Where an SSO adopts a general rule regarding disclosure or licensing of IP rights that binds only its members, that rule should not normally create antitrust concern. Only where an SSO acts in a specific case to favor one set of members over an IP owner should section

243. Cf. Jaap H. Spoor, Standardization and Exclusivity in Intellectual Property, in INFoRMatron LAw TOWARDS THE 2IST CENTURY 374 (Kluwer 1992) (noting that asymmetric licenses can create antitrust problems).

244. See, e.g., Radiant Burners, Inc. v. Peoples Gas Light \& Coke Co., 364 U.S. 656, 659-60 (1961) (per curiam) (requiring that a standard set by an SSO be made equally available to all competitors).

245. See The 3G Patent Platform Partnership, Welcome to the $3 G$ Patent Platform, at http://www.3gpatents.com (last updated May 28, 2002) (describing an SSO that is designed to cap total fees paid to patentees that own rights in the $3 \mathrm{G}$ telephony standard).

246. See, e.g., Jack E. Brown, Technology Joint Ventures to Set Standards or Define Interfaces, 61 ANTrTRUST L.J. 921 (I993); Jonathan T. Howe \& Leland J. Badger, The Antitrust Challenge to NonProfit Certification Organizations: Conflicts of Interest and a Practical Rule of Reason Approach to Certification Programs as Industry-Wide Builders of Competition and Efficiency, 60 WASH. U.L.Q. 357 (1982) (endorsing a fact-specific rule-of-reason approach); Lemley, Internet Standardization, supra note 11, at 1080 (making this argument); Piraino, supra note 11; Teece, supra note 11. 
1 liability be an issue. Even then, only certain types of concerted licensee conduct will raise antitrust concerns.

\section{$\mathrm{V}$ \\ Standard-Setting Organization Intellectual Property Rules as Private Ordering in the Shadow of Patent LaW}

\section{A. Intellectual Property Rules as Efficient Private Ordering}

Economic scholarship has demonstrated that while IP rights sometimes promote innovation, at other times they can actually impede it. This is particularly true in industries where innovation is cumulative, because granting strong IP rights to initial innovators restricts the options available to improvers. ${ }^{247}$ Other work has shown that IP rights are rarely enforced in

247. There are at least three strands to this argument. First, for a variety of reasons, society cannot rely on pioneers to license efficiently to would-be improvers the right to compete with them. As Rebecca Eisenberg has noted:

The risk that the parties will be unable to agree on terms for a license is greatest when subsequent researchers want to use prior inventions to make furthcr progress in the same field in competition with the patent holder, especially if the research threatens to render the patented invention technologically obsolete.

Rebecca S. Eisenberg, Patents and the Progress of Science: Exclusive Rights and Experimental Use, 56 U. ChI. L. Rev. 1017, 1072-73 (1989). See Matthew J. Conigliaro et al., Foreseeability in Patent Law, 16 Berkeley Tech. L.J. 1045 (2001); Lemley, supra note 2, at 1048-72 (offering a variety of reasons why granting exclusive control to pioneers is inefficient); Merges, supra note 211; Robert P. Merges \& Richard R. Nelson, On the Coinplex Economics of Patent Scope, 90 Colum. L. REv. 839 (1990).

Second, positive "spillovers" from innovation that cannot be appropriated by the innovator actually contribute to further innovation. See, e.g., Wesley M. Cohen \& David A. Levinthal, Innovation and Learning: The Two Faces of R\&D, 99 EcoN. J. 569 (1989); Zvi Griliches, The Search for R\&D Spillovers, 94 SCAND. J. EcoN. S29 (1992); Richard C. Levin, Appropriability, R\&D Spending, and Technological Performance, 78 AM. EcoN. REv. 424, 427 (1988); Richard Schmalensee, $R$ and $D$ Cooperation and Competition: Comments and Discussion, 1990 BroOKINGS PAPERS ON ECON. Activity 194, 195-96 (Michael L. Katz \& Janusz A. Ordover eds., 1990); cf. Suzanne Scotchmer, Protecting Early Innovators: Should Second-Generation Products Be Patentable?, 27 RaND J. ECON. 322 (1996) (noting difficulties in the optimal allocation of rights between pioneers and improvers).

Third, granting strong IP rights encourages rent seeking, which may dissipate the social value of the property rights themselves. In the patent context, giving too strong a right to first inventors would encourage wasteful patent races. See, e.g., Robert P. Merges, Rent Control in the Patent District: Observations on the Grady-Alexander Thesis, 78 VA. L. REv. 359 (1992); Jennifer F. Reinganum, The Timing of Innovation: Research, Development, and Diffusion, 1 HaNDBOOK OF INDUS. ORG. 850 (Richard Schmalensee \& Robert Willig eds., 1989); cf. Mark F. Grady \& Jay I. Alexander, Patent Law and Rent Dissipation, 78 VA. L. REv. 305 (1992).

Of course, the operative word here is balance. Pioneering inventors will emerge only if there are sufficient incentives for them to invent. At the same time, too great a division of rights can impede effective use of technologies. See Heller \& Eisenberg, supra note 211. The fact that the law must also encourage competition to improve such pioneering inventions means that the law must take care to allocate rights between the parties. See Nard, supra note 179 , at 36-40.

For discussions of how to optimize that allocation, see, for example, John H. Barton, Patents and Antitrust: A Rethinking in Light of Patent Breadth and Sequential Innovation, 65 ANTIrRUST L.J. 449, 453 (1997); Howard F. Chang, Patent Scope, Antitrust Policy, and Cumulative Innovation, 26 RAND J. 
court or licensed for a royalty, the uses that traditional incentive theory would predict. ${ }^{248}$ In a significant number of cases, then, IP rights may not enhance and may actually hinder the optimal development of technology.

This doesn't necessarily mean that granting IP rights is a bad idea, however. Private parties can sometimes enter into licensing arrangements to avoid potential obstacles. Traditional IP licenses grant the right to use the IP in exchange for a royalty payment. But in many industries IP owners regnlarly cross-license huge stacks of patents on a royalty-free basis. These patents are used defensively rather than offensively; their primary economic value is as a sort of trading card that reduces the risk that their owner will be held up by other patent owners. Such defensive use is particularly important in the semiconductor industry, where a new microprocessor design may be covered by thousands of patents on circuit design, layout, materials, manufacturing processes, and packaging. ${ }^{249}$

These bilateral, ad hoc cross-licensing arrangements are most effective in avoiding holdups when the stakes are symmetrical. If Intel and Motorola each have two hundred patents that they think the other infringes, neither is likely to benefit much from protracted litigation. Indeed, there is some risk that both companies will be enjoined from selling their products.

Econ. 34 (1995); Jerry R. Green \& Suzanne Scotchmer, On the Division of Profit in Sequential Innovation, 26 RAND J. EcoN. 20 (1995).

248. See Mark A. Lemley, Rational Ignorance at the Patent Office, 95 Nw. U. L. REv. 1495, 1501-07 (2001) [hereinafter Lemley, Rational Ignorance] (finding that only 1.5\% of all patents are ever litigated and only $5 \%$ are ever licensed for a royalty).

249. As I discussed previously,

many patentees engage in "defensive patenting," obtaining patents to stake their claim to an area of technology in hopes of preventing other companies from suing them. Indeed, there is anecdotal evidence that at least among high-technology and start-up companies, the primary purpose of patents is defensive. Licensing patents for royalties is correspondingly uncommon in many industries in which all the major players have large patent portfolios. Patent licensing in such an industry has a very different character from the typical model of licensing for royalties. Large companies tend to come to the table with hundreds of patents on each side, relying on volume rather than quality in a sort of "patent arms race." While some crosslicensing deals in such industries are royalty-bearing, it is more common for companies to agree to royalty-free cross-licenses, in which each party gets the freedom to make products but does not have to pay the other. Similarly, in many high-technology industries patent rights are waived (or licensed on a royalty-free basis, which amounts to the same thing) because the patented technology is adopted as an industry standard.

Id. at 1504-05.

For detailed empirical evidence of such cross-licensing in the semiconductor industry, see Bronwyn Hall \& Rose Marie Ham Ziedonis, The Patent Paradox Revisited: Determinants of Patenting in the U.S. Semiconductor Industry, 1980-1994, 32 RAND J. EcoN. 101 (2001). See also John H. Barton, Reforning the Patent System, 287 ScI. 1933 (2000) (arguing that reducing the number of patents would "help to solve the problem of defensive patent portfolios"); Mark A. Lemley, Reconceiving Patents in the Age of Venture Capital, 4 J. SMALL \& EMERging Bus. L. 137, 143 (2000) ("One of the major reasons that companies get patents is that they're afraid that their competitors have them, and they don't want to be the only one left who doesn't have the ability to play in this game."); Scott Herhold, Patent War, SAN JOSE Mercury News, July 18, 1999, at IE (quoting a venture capitalist as saying, "[n]one of my companies seek patent protection because they actually think it will protect them from competition.... Rather, they seek patents to protect themselves from other people who have patents"). 
In such symmetrical cases, the cross-license is an effective solution. By contrast, parties without much to lose-individual patent owners or companies like Texas Instruments or Rambus, which hold major patent portfolios but have either no products or very little market share-are more likely to prosecute suits to completion. ${ }^{250}$ The cross-license isn't an effective solution in such a circumstance.

Cross-licenses tend to be relatively narrow remedies that consist of ad hoc, one-time contracts. But IP owners have also pursued broader solutions, developing institutions designed to reduce the holdup risk of IP rights. In a path-breaking work, Rob Merges studied what he calls "collective rights organizations," industry groups that collect IP rights from owners and license them as a package. ${ }^{251} \mathrm{He}$ finds that these organizations ease some of the tensions created by strong IP rights by allowing industries to bargain from a property rule into a liability rule. ${ }^{252}$ Collective rights organizations thus play a valuable role in facilitating transactions in IP rights. They permit commerce in copyrighted content and patented inventions to proceed without being subject to an almost endless string of holdups by IP owners who have the power to enjoin the use of their IP.

Merges discusses two basic sorts of collective rights organizations: patent pools and music licensing collectives. ${ }^{253}$ Collective rights organizations of this sort tend to spring up after the core IP rights have been created. Indeed, patent pools in particular are often created as a response to nultiple patent infringement suits within an industry. They are most effective when the patent rights in question are blocking, so that no one can make a given product without licenses from at least one other firm. ${ }^{254}$ Patent pools have diverse organizational forms, ranging from informal understandings that look like nultiparty cross-licensing arrangements to

250. See Lemley, Rational Ignorance, supra note 248, at 1505 ("[P]atentees who want to license their patents for royalties are typically parties with asymmetric stakes-they are individuals who don't sell products, 'licensing shops' whose primary output is patents, or older companies that are no longer major players in the marketplace.").

251. Robert P. Merges, Contracting Into Liability Rules: Intellectual Property Rights and Collective Rights Organizations, 84 CALIF. L. Rev. 1293 (1996) [hereinafter Merges, Liability Rules].

252. See, e.g., Guido Calabresi \& A. Douglas Melamed, Property Rules, Liability Rules, and Inalienability: One View of the Cathedral, 85 HARv. L. REv. 1089 (1972) (discussing the difference between property-rule regimes, in which the owner of a right is entitled to an injunction, and liabilityrule regimes, in which a right is enforced only by requiring payment of damages to compensate for the owner's loss).

253. Merges, Liability Rules, supra note 251. See also Robert P. Merges, Institutions for Intellectual Property Transactions: The Case of Patent Pools, in Expanding the Boundaries of INTEllectual Property 123 (Rochelle Cooper Dreyfuss et al. eds., 2001).

254. See, e.g., Carpet Seaming Tape Licensing Corp. v. Best Seam, Inc., 616 F.2d 1133, 1142 (9th Cir. 1980) ("A well-recognized legitimate purpose for a pooling agreement is exchange of blocking patents."); United States Dep't of Justice \& the Fed. Trade Comm'N, Antitrust Guidelines for the Licensing of Intellectual Property $\$ 5.5$ (1995); Steven C. Carlson, Patent Pools and the Antitrust Dilemma, 16 YALE J. ON REG. 359 (1999) (arguing that the legality of patent pools should depend on whether the patents in fact are blocking). 
pools that are institutions in their own right and behave in some respect like joint ventures. ${ }^{255}$ Collective rights organizations are found in all sorts of industries, from automobiles to aircraft to music. ${ }^{256}$ Because they are almost always organized by industry participants who own IP rights, and who therefore have a stake in how the pool is structured, they present substantial risks of collusion. ${ }^{257}$ As a result, patent pools and copyright collective rights organizations have repeatedly been the subject of antitrust litigation. ${ }^{258}$

SSOs behave like patent pools in certain respects. They are frequently, though not always, run by industry participants, and they may ameliorate the problems of overlapping IP rights by requiring licensing on reasonable and nondiscriminatory terms. But there are important differences between SSOs and patent pools. First, unlike patent pools, SSOs tend to be organized around technical outcomes. The goal of an SSO is first and foremost to design a standard for the industry to use, not to worry about licensing IP rights. By contrast, patent pools are formed around patents, and often have little technical content beyond that necessary to determine appropriate royalty rates.

Second, SSO IP rules tend to be set ex ante, while patent pools more often allocate their rights ex post. ${ }^{259}$ SSOs do not design IP rules around particular patents that have been brought to their attention, or even around particular standards that they are setting. Rather, SSOs tend to set a uniform IP policy and apply it across the board (at least if the policy is working properly). This ex ante approach has significant advantages. Because the members of the SSO generally don't know in advance whether they will be the owner or the licensee of any particular IP right, the policy is nore likely to be drafted evenhandedly. ${ }^{260}$ Indeed, there is significant economic literature suggesting that rules drafted in this way are more likely to

255. Merges, Liability Rules, supra note 251 (studying many of these organizations).

256. See id. (discussing numerous examples).

257. See John H. Barton, Antitrust Treatment of Oligopolies with Mutually Blocking Patent Portfolios, 69 AnTITRUST L.J. 851 (2002). Barton goes beyond the statement in the text, contending that blocking portfolios restrict competition whether or not there is collusion.

258. See, e.g., 2 HovenKAMP ET AL., supra note 34, ch. 34; Stanley M. Besen et al., An Economic Analysis of Copyright Collectives, 78 V. L. REv. 383 (1992); Merges, Liability Rules, supra note 251; Shapiro, Thicket, supra note 11; Josh Lerner \& Jean Tirole, Theoretical and Empirical Perspectives on Patent Pools: A Progress Report (2002) (draft working paper, on file with author); Richard J. Gilbert, Patent Pools: 100 Years of Law and Economic Solitude (May 5, 2002) (draft working paper, on file with author).

259. See Schallop, supra note 11, at 269-70. There is a continuum here, of course. Some SSOs set their rules ex post, especially if the SSO itself is created around a single standard, and some patent pools are long-standing groups. But as a general matter the distinction drawn in the text is accurate.

260. See, e.g., Farrell, Choosing, supra note 37, at 15-16, 19. But see David J. Teece \& Edward Sherry, Standards Setting and Antitrust 13-14 (2002) (draft working paper, on file with author) (arguing that SSOs are likely to be biased in favor of users because engineers dislike patents). 
have an information-forcing effect, ${ }^{261}$ inducing members to disclose their real position on IP licensing and perhaps to exit the SSO if they disagree with the policy adopted. Bargaining under the veil of ignorance is particularly likely to solve holdup problems in which society as a whole would benefit from a deal, but once property entitlements are distributed those who receive them have an incentive to "hold up" others for a disproportionate share of the returns. ${ }^{262}$ Further, the SSO can make it clear up front whether the standards it adopts will be fully open (no IP rights allowed), proprietary but with mandatory licensing on reasonable terms, or closed (fully proprietary). This clarity in turn allows the market to evaluate the full costs and benefits of competing standards. Ex ante policy setting also reduces the risk that a particular policy will be adopted or used merely as a front for a cartel. As a result, ex ante SSO IP policies should generate fewer antitrust problems than patent pools. This argument also suggests that antitrust might look more favorably on preexisting policies than ones changed midstream, and that the IP policies of continuing groups may create fewer problems than those of newer consortia built around a single standard.

Third, unlike patent pools, interface SSOs of the type I have focused on in this Article aren't distributed randomly across industries. Rather, they tend to be concentrated in network industries like software, Internet, telecommunications, and semiconductors. ${ }^{263}$ All of these industries are characterized by at least virtual and sometimes actual network effects, ${ }^{264}$ making

261. There is a voluminous literature on the design of rules with information-forcing effects. Rules that cause parties to have incentives to accurately disclose private information, such as their valuations, are generally desirable, though they can be hard to achieve. For discussions, see Barry E. Adler, The Questionable Ascent of Hadley v. Baxendale, 51 STAN. L. Rev. 1547 (1999); Ian Ayres \& Robert Gertner, Majoritarian vs. Minoritarian Defaults, 51 STAN. L. Rev. 1591 (1999) [hereinafter Ayres \& Gertner, Defaults]; Ian Ayres \& Robert Gertner, Strategic Contractual Inefficiency and the Optimal Choice of Legal Rules, 101 YALE L.J. 729 (1992) [hereinafter Ayres \& Gertner, Contractual Inefficiency]; Jason Scott Johnston, Strategic Bargaining and the Economic Theory of Contract Default Rules, 100 YALE L.J. 615 (1990).

262. See generally Mancur Olson, The Logic of Collective Action (1960) (describing the holdup problem).

263. See, e.g., Anton \& Yao, supra note 11, at 247 ("Interface standards are of primary interest in telecommunications and information technology industries."); Steven Oksala et al., The Stricture of IT Standardization, 4 STANDARDVIEW 9, 10 (1996) (majority of all new standards are developed in the 1T sector); Shapiro, Thicket, supra note 11, at 119-20; Surowiecki, supra note 1, at 87 ("[T]he really crucial standards govern information technologies like wireless communications and the Internet."); Lucash, Gesmer \& Updegrove, LLP, Consortium \& Standards List, at http://consortiuminfo.com/ ssl/links.php?cat=1 (last visited Sept. 9, 2002) (collecting consortia, primarily in the Internet and software industries); see also Mueller, Misuse, supra note 8, at 631 ("[O]ne or more hardware or software standards govern virtually every aspect of using a computer or connecting to the Internet."). While Mueller also notes the role of standards in biotechnology, see id., biotechnology standards are largely limited to bioinformatics, the area of biotechnology that intersects with computing.

264. On different types of network effects and their strengths, see Katz \& Shapiro, supra note 15, at 424; Katz \& Shapiro, supra note 16, at 95; Lemley \& McGowan, supra note 15, at 488-95; Liebowitz \& Margolis, supra note 15, at 135. 
interoperability between products at both the vertical and horizontal levels particularly important. These are also the industries in which growing economic evidence suggests that patents create the most difficulties. ${ }^{265}$ Patents in these industries are easier to obtain and are subject to less PTO scrutiny than those in industries like pharmaceuticals, biotechnology, and chemistry. ${ }^{266}$ They are inore likely to block each other, more likely to interfere with cumulative innovation across multiple product generations and, because a single product may require licenses from many different patents, are more likely to lead to holdups. ${ }^{267}$ Even where patent owners do not use injunctive relief to preclude innovation altogether, the costs of licensing rights from multiple owners at a monopoly rate will be inefficiently high. ${ }^{268}$ Patents in these industries also appear to be less valuable to their owners

265. The arguments in this paragraph are conclusory in nature. For a much more detailed analysis, and more citations, see Dan L. Burk \& Mark A. Lemley, Policy Levers in Patent Law (vaporware 2002).

266. Semiconductor and electronics inventions have fewer claims, cite less prior art (especially nonpatent prior art), spend less time in the PTO, and have a less involved prosecution than patents on average, and in particular than patents in the pharmaceutical and biotechnology industries. See John R. Allison \& Mark A. Lemley, Who's Patenting What? An Empirical Exploration of Patent Prosecution, 53 VAND. L. REV. 2099, 2134-42, 2146 (2000); see also Allison \& Lemley, supra note 4, at 134.

267. See, e.g., Shapiro, Thicket, supra note 11, at 124-26; Krechmer, supra note 6, at 3 ("The increase in patents and claims often results in multiple patent holders claiming rights to the technologies within a single communications standard."). Bekkers and Liotard argue that the importance of IP rights, and in particular the problem that "standard designers cannot work around existing, protected knowledge," is greater in telecommunications than in other areas. See Bekkers \& Liotard, supra note 96 , at 115 . There has also been a great deal of discussion about the overlap problem in the particular context of software. See, e.g., Burk \& Lemley, supra note 265; Cohen \& Lemley, supra note 5, at 40-42; Mark A. Lemley \& David W. O'Brien, Encouraging Software Reuse, 49 STAN. L. REv. 255 (1997); Peter S. Menell, An Analysis of the Scope of Copyright Protection for Application Programs, 41 StAN. L. REv. 1045 (1989); Merges, Bargaining Breakdown, supra note 211, at 75; Samuelson et al., supra note 5; James Bessen \& Eric Maskin, Sequential Innovation, Patents, and Imitation (1999) (draft working paper, on file with authors), available at http:// www.researchoninnovation.org/patent.pdf.

To take just one example, the developing $3 G$ Wireless Internet standard in Europe involves essential technologies patented by at least one hundred different companies. See $3 G$ Patent Platform, supra note 245.

Michael Heller and Rebecca Eisenberg discuss what they call the "anticommons" problem in IP, which arises when property rights are inefficiently divided among too many parties. Heller \& Eisenberg, supra note 211; Michael A. Heller, The Tragedy of the Anticommons: Property in the Transition from Marx to Markets, 111 HARv. L. REv. 621 (1998). While Heller and Eisenberg talk about overly divided entitlements in one particular type of biomedical research-gene sequence patents-the problem is much greater in fields like semiconductors.

268. This is a result of the double-marginalization theorem, which shows that it is inefficient to grant two monopolies in complementary goods to two different entities because each entity will price its piece without regard to the efficient pricing of the whole, resulting in an inefficiently high price. For a technical proof of this, see Carl Shapiro, Setting Compatibility Standards: Cooperation or Collusion?, in Expanding the Boundaries of Intellectual Property 81, 97-101 (Rochelle Cooper Dreyfuss et al. eds., 2001) [Hereinafter Shapiro, Cooperation or Collusion]. For a description of the problem in practice, see Krechmer, supra note 6, at 3 (citing examples in which so many different IP owners claim rights in a standard that the total cost to license those rights exceeds the potential profit from the product); Lichtman, supra note 212. 
than patents in industries like chemistry and pharmaceuticals. ${ }^{269}$ And for at least some of these industries, such as software and the Internet, the fixed costs of innovation are relatively low. ${ }^{270}$

Patents in these fields can still serve valuable purposes. But it is striking that SSOs have developed IP policies that require at least disclosure of IP, and often blanket licensing for either no royalty or a reasonable royalty, in precisely those industries where the unconstrained enforcement of patents could be most damaging to innovation. In theory at least, SSOs appear to be an efficient species of private ordering when it comes to IP, allowing bargaining in the shadow of IP law to better meet the needs of the industries in which they exist. ${ }^{271}$

\section{B. The Reality of "Messy" Private Ordering}

There is an important caveat to the conclusion of the last Section that SSO IP rules efficiently "contract around" patent rights. Private ordering is efficient only if the contracting parties have the proper information, the market is competitive, and the costs and benefits of the private agreement are internalized by the parties.

As we have seen, SSOs are remarkably diverse in their IP rules. This diversity raises some questions about the efficiency rationale I offered above. Why do different SSOs treat IP so differently? ${ }^{272}$ One possibility is that the SSOs are responding to different market pressures, and that it makes sense for different SSOs to have different policies. The increased

269. See, e.g., COHEN ET AL., supra note 3 (same); Levin et al., supra note 3, at 796-98 (surveying licensing managers in various industries and finding that patents are important only in a few industries, notably pharmaceuticals and chemistry). More recent work values the patent premium in terms of its effects on $R \& D$ and finds that patents promote $R \& D$ more in drugs and biotechnology than in fields such as electronics. See Ashish Arora et al., R\&D and the Patent Premium (Feb. 25, 2002) (draft working paper, on file with author). This result is entirely consistent with the discussion in the text.

270. See, e.g., Burk \& Lemley, supra note 265.

271. Because SSO IP rules are private, not public, they do not raise any of the standard concerns that would accompany legislative efforts to eliminate or restrict patents in certain industries. Contra Mueller, Misuse, supra note 8, at 24 (raising these conccrns).

272. Some scholars have suggested that private actors are likely to standardize particular terms over time because of the benefits of custom and judicial interpretation of those terms. See, e.g., Marcel Kahan \& Michael Klausner, Antitakeover Provisions in Bonds: Bondholder Protection or Management Entrenchment?, 40 UCLA L. REv. 931 (1993); Marcel Kahan \& Michael Klausner, Path Dependence in Corporate Contracting: Increasing Returns, Herd Behavior and Cognitive Biases, 74 WASH. U.L.Q. 347 (1996); Marcel Kahan \& Michael Klausner, Standardization and Innovation in Corporate Contracting (Or "The Economics of Boilerplate"), 83 VA L. REv. 713 (1997); Michael Klausner, Corporations, Corporate Law, and Networks of Contracts, 81 VA. L. REv. 757 (1995). For more skeptical views, see Lemley \& McGowan, supra note 15, at 562-90; Larry E. Ribstein \& Bruce H. Kobayashi, Choice of Form and Network Externalities, 43 WM. \& MARY L. REv. 79 (2001). SSO IP rules provide ambiguous evidence in this debate. On the one hand, the diversity of policies in general argues against any sort of strong network effect or herd behavior. On the other hand, there are specific terms that seem to have been widely adopted. A notable example of such a term is "reasonable and nondiscriminatory licensing." While there has not been much in the way of judicial explication of this term so far, its common usage may give courts more opportunity to clarify its meaning. 
cost and uncertainty associated with the diversity of SSO approaches might be justified if there was some evidence that the different approaches taken by different SSOs in fact reflected considered policy judgments as to the proper role of IP in standard setting in a particular market. ${ }^{273}$ Certainly this is sometimes true. The SSOs that elect to require royalty-free licensing of IP rights, for example, generally do so because they hope to ensure that the standard they adopt is an open one. But much of the diversity is harder to justify on efficiency grounds, particularly since all of the SSOs I studied operate in the same cluster of industries. Many SSOs have no policy at all. Among those that do, some of the policies are internally inconsistent. Even among the set of SSOs with consistent policies, it isn't clear that the policies differ from SSO to SSO because of any affirmative judgment in favor of a particular policy. For example, it is hard to explain why some SSOs would want to require disclosure of patent applications and others only issued patents, or why some SSOs, but not others, would require searches. Nor is it clear that the choice of a disclosure-based or licensing-based policy is driven by efficiency. ${ }^{274}$

There are some reasons to think that SSO IP rules might not be created in a perfectly efficient market, and that the resulting private ordering will not necessarily be efficient. Negative externalities imposed on other IP owners should not be a great problem, since SSO IP rules can directly affect the IP rights only of those members who agree to be bound. Adoption of a standard will confer positive externalities on nonmenber IP owners, whose IP rights may experience a sudden windfall. ${ }^{275}$ The rules might have second-order effects on consumers of a standard, however, since an SSO rule that affects the structure of a market will affect consumers of the resulting standard. But those effects will largely be internalized by members.

273. See Schallop, supra note 11, at 234 (suggesting that the variance in IP policies creates a sort of competition, with the most efficient IP rule likely to prevail). Schallop offers no evidence to believe there is effective competition between different types of SSO IP rules, and my strong suspicion is that the success or failure of any given SSO has far more to do with its membership and the technical merits of the standards it selects than with its IP policies.

274. An alternative explanation is that the market is in the process of correction, and that policies will converge over time on a single optimal rule. Thus, Updegrove argues that while SSOs had diverse policies in the past, "a consensus on a range of appropriate intellectual property policy solutions is emerging" with disagreements primarily on issues of secondary importance. Updegrove, supra note 11, at 1. At the same time, Updegrove notes tremendous variance in attitudes, and offers this example:

[T] he author has had several situations in which he has spoken with two different representatives (often lawyers) of the same company, on the same day, relating to two different consortia, and encountered two different positions on the same issues. Each time, the two points of view were adamantly espoused-aud diametrically opposed. Id. at 9.

275. On this problem and how to control it, see Gifford, supra note 11, at 12; Patterson, supra note 11 , at 10 . As one measure of this windfall, Patterson notes that Rambus charged a $0.75 \%$ royalty for ordinary patents, but a $3.5 \%$ royalty for patents that had been incorporated in a standard. Id. at 17 n.46. of course, they also got sued. 
of the SSO, at least to the extent that members are the ones selling the products that embody the standard.

Imperfect information is a more serious problem in two respects. First it may lead to inefficient creation of SSO policies in the first instance. IP rules have largely been an afterthought for most SSOs. SSOs are made up of engineers who want to pick the right technical standard, not lawyers who want to clear rights. Indeed, this is one of the things that distinguishes SSO IP rules from the more established patent pools. Pools are set up precisely in order to clear IP rights, so they take account of a variety of important legal issues. SSO IP rules, by contrast, are often put together without much participation by lawyers, and without much thought to the sorts of disputes that might arise. My informal investigation suggests that new SSOs often copy the rules from whatever existing SSO they happen to be familiar with, and that even existing SSOs often write a policy on an ad hoc basis, reacting to a particular issue that arose in the SSO, rather than as part of a considered effort to develop a policy.

Second, even if an SSO chooses a good policy, the efficiency of that policy may be put at risk by imperfect information. SSO IP rules may not always be clearly communicated to members, who as a result may not have made an informed decision to join the SSO. Even if members are aware of the policy, the individuals who attend SSO meetings are likely to be engineers who may have little interest in their company's IP. Indeed, anecdotal evidence suggests that the engineers who participate in SSOs may sign disclosure or licensing agreements without reading them, much less consulting with company lawyers to determine what IP may cover the standard. Further, the fact that many SSOs discourage any discussion of patents or potential licenses for fear of antitrust consequences means that even an SSO that has adopted a disclosure and licensing policy with which all members have complied isn't fully informed about the costs of a particular standard.

Inefficient provision of services is normally taken care of in a market economy by competition. But because SSOs involve groups of competitors jointly setting a policy, they will not always face a competitive market. While some markets have multiple SSOs competing to set a standard, SSOs that count as members most players in the market may not face such competition. SSOs are really a sort of hybrid between top-down public ordering and bottom-up emergent rules. ${ }^{276}$ Indeed, some of the SSOs I studied are quasi-governmental in nature. ${ }^{277}$ Further, the fact that SSOs approach IP rules as an afterthought in most cases means that the ordinary discipline of a competitive market may be lacking. Companies choose to

276. Cf. Kesan \& Shah, supra note 26 (discussing these hybrids in the context of the Internet).

277. For example, ETSI has quasi-official status within the European Union, and ISO voting members are all governments rather than private actors. 
join SSOs because of the market they are in, the identity of other members, and the standards they select. If IP rules enter into the calculus at all, they are well down the list. Thus, SSOs have little incentive to compete on the basis of their IP policy to attract members, and the market will not punish an SSO that selects an objectively inferior IP policy.

SSO IP rules are a "messy" form of private ordering, the result of a decision-making process that, like making sausages or legislation, does not always reward close scrutiny. Thus, it may be fairer to say that SSO IP rules have the potential to be an efficient ex ante bargaining solution to excessive or overlapping IP rights. Whether the IP rules are in fact efficient depends on how the rules are designed, implemented, and enforced. In the next Part, I offer suggestions for optimizing SSO IP rules.

\section{VI \\ Designing Optimal Standard-Setring Organization Policies}

In this Part, I offer a series of ideas for how to optimize SSO IP rules. If SSOs operated in an efficient market, telling them how best to survive would smack of temerity. But as I noted in the last Part, many SSO IP rules are adopted ad hoc, with relatively little thought given to the consequences of the rules. They are ambiguous on important terms. ${ }^{278}$ And for a variety of reasons, the market is unlikely to drive these rules towards efficiency. If SSO IP rules are to fulfill their promise as efficient solutions to IP holdup problems, those rules must be transparent and fair. In this Part I offer several suggestions that will help SSOs clarify their rules, give them greater specificity, and make them fairer. I also offer suggestions to courts and policymakers on how to treat SSO IP rules.

\section{A. Optimizing Standard-Setting Organization Intellectual Property Rules: Suggestions for Organizations and Members}

\section{Define the Intellectual Property Rights in Question}

Many SSO IP policies apply only to issued patents and do not discuss patent applications. ${ }^{279}$ Most policies do not consider whether foreign or only U.S. patents are covered. Still other policies cover patents but not copyrights. ${ }^{280}$ This lack of clarity might be the result of a deliberate decision, but it more likely reflects sloppy drafting that can have real-world consequences.

278. See, e.g., Cowie \& Lavelle, supra note 11, at 100-01 (“[M]ost SSOs have not adopted regulations that are nearly specific enough to address the issues that arise in patent litigation regarding patents related to the standard.").

279. See supra Part II.B.

280. See id. 
Proposed standards often find their way to an SSO while the technology is still new. Because patents take almost three years on average to issue, ${ }^{281}$ it is quite common for members to have patent applications outstanding but no issued patents at the time the SSO votes on the standard. SSOs should deal with this problem up front by making it clear that their IP rules apply to patent applications as well as to issued patents. ${ }^{282}$ Covering pending applications is especially appropriate for rules that require licensing on specified terms rather than disclosure. ${ }^{283}$ Indeed, it probably makes sense to apply those rules to nascent IP that has not yet even matured into a patent application. Similarly, because most standards in the telecommunications and computer industries are global, it makes sense for SSO rules to cover all patents worldwide, not just patents in the United States. In many industries, particularly software and the Internet, it is also advisable to extend the policies to cover copyrights. Failure to specify broad coverage for an IP policy will leave putative IP owners with the power to shut down a standard at some point after it is adopted. It will also leave the true scope of the policy ambiguous, as Rambus pointedly shows. ${ }^{284}$

A more difficult question concerns which patents fall within the scope of a disclosure or licensing requirement. Obviously, IP rights that are coextensive with a standard will be covered by any IP policy. Similarly, any IP rights that are necessary as a practical matter in order to implement the standard will likely be covered, even if the patent in question only covers a subset or component of the standard. ${ }^{285}$ But from there things get murkier. ${ }^{286}$ What about patents that are useful but not necessary in implementing a standard ${ }^{287}$ Those that cover the most common commercial embodiment, but which could be designed around with some effort? Further, to what extent should the policy cover patents that do not literally reach a standard,

281. See Allison \& Lemley, supra note 266, at 2118 (finding an average of 2.77 years for patents issued between 1996 and 1998).

282. Accord Kipnis, supra note 11, at 104 (suggesting that SSO IP rules should apply to patent applications).

283. While 1P owners might object to required disclosure of patent applications, which the law permits to be kept secret for the first eighteen months after filing, 35 U.S.C. $\$ 122(2000)$, there is no analogous ground to object to a reasonable and nondiscriminatory licensing requirement for a patent application.

284. See supra notes $180-85$ and accompanying text. In Rambus, the court ultimately held that JEDEC's policy applied to patent applications, even though on its face it covered only issued patents.

285. See Feldman et al., supra note 11, at 113 ("The incorporation of a basic patent into a standard is likely to be uncontroversial."). Cf. Shapiro, Thicket, supra note 11, at 125 (discussing the definition of essential patents).

286. See Schallop, supra note 11, at 229 (arguing that the meaning of essential patents is "generally ambiguous and can leave plenty of wiggle room for legal negotiating in a dispute").

287. At least one eourt has found that both "optional" and "required" features of a software standard were covered within a standards license, where the license did not expressly differentiate the two. See Intel Corp. v. VIA Techs., Inc., 174 F. Supp. 2 d 1038 (N.D. Cal. 2001). 
but which might be extended to encompass it under the "doctrine of equivalents?"288

An SSO's first instinct will likely be to bring as many patents as possible within the scope of the policy. This may be a mistake, however. Including unnecessary patents will complicate the disclosure and licensing processes. Members who own IP rights may also exploit the policy. It is a common practice among some IP owners to disclose as many patents as possible to an SSO, both in order to avoid possible liability for nondisclosure and to try to obtain royalty payments. ${ }^{289}$ Still other members might drop out of an SSO altogether rather than risk granting blanket licenses to all their IP. Limiting the scope of the IP rules so that they cover only essential IP will minimize these probleins. It will also help an SSO avoid antitrust scrutiny. In the analogous context of patent pools, the DOJ has looked more favorably upon patent pools that were limited to necessary patents, because they presented less risk of industry-wide collusion. ${ }^{290}$

Once the rights in question are defined, the SSO should endeavor to make clear to the public what rights are clained. The easiest way to do this is to post on the Internet all claims of right respecting a particular standard, as the IETF does. ${ }^{291}$ Whether the world will search such a list is another matter. ${ }^{292}$ But they should at least be given the opportunity to do so.

288. The patent doctrine of equivalents permits patent owners to argue infringement, even though the accused device does not fall within the literal scope of the patent claims, if the differences between the patent claims and the accused device are merely insubstantial. See, e.g., Wamer-Jenkinson Co. v. Hilton Davis Chem. Co., 520 U.S. 17, 36 (1997).

The doctrine of equivalents problem is made even less tractable by the fact that the scope of a patent can actually change over time, expanding to cover equivalents developed after the patent was written. This is a result of the fact that equivalence is tested at the time of infringement, not at the time the invention is made. For a discussion of after arising technology, see Conigliaro et al., supra note 247; Merges \& Nelson, supra note 247.

289. See, e.g., CarL Shapiro \& Hal R. Varian, Information Rules 239 (1999) (describing an example of this in the setting of modem standards); Joanne Taaffe, $3 G$ Patents Initiative Devised to Avoid "Qualcomm-type" Disputes, Comm. WK. INT'L, June 19, 2000 ("What certain companies have done is declare more essential patents than they had."); conversation with Robert Barr, Cisco Systems (Jan. 2002) (describing similar strategic behavior that is common in the IEEE) [hereinafter Conversation with Robert Barr].

290. See U.S. Dep't of Justice, Response to Request for Issuance of Business Review LETTER (Dec. 16, 1998), in Mary L. Azcuenaga, Antitrust Issues, I 93 PLV/Corp 457, app. C at 528-33 (2000) (regarding DVD patent pool).

291. See The Internet Engineering Task Force, supra note 7.

292. Under patent law's willfulness doctrine, a company can be held liable for treble damages if it knew of a patent and continued to infringe. As a result, many companies discourage their employees from engaging in any sort of a patent search because they are afraid of the consequences of discovering a patent. Those companies might similarly be disinclined to search an SSO's website for patents. But if the SSO requires reasonable and nondiscriminatory licensing, treble damages presumably will not be a risk in any event. 


\section{Take Process Seriously}

SSO IP rules are worth nothing unless they are enforceable. Indeed, unenforceable rules are probably worse than useless because they may create false expectations among members and the public. To maximize enforceability, SSOs that go to the trouble of creating rules to control the use of IP rights should make sure that the process is as transparent and as fair as possible. ${ }^{293}$ SSOs should treat their IP rules just as they would treat any other contract. Ideally, members should affirmatively consent to the SSO's IP rules in writing. While affirmative consent may not be necessary as a matter of contract law, ${ }^{294}$ it will strengthen the legal and moral case for later enforcing the rules, and it may be more important for the IP doctrines of implied license and estoppel. At a bare minimum, the policy should be in writing and should be distributed to all members. Requiring members to certify that they are disclosing or licensing any relevant patents each time they vote on a standard is also a good idea. Policies should also make their duration clear, and specify what rights a member who wishes to leave the SSO will have to assert its IP against existing, pending, and future standards.

Policies should not only be fairly made but also fairly enforced. Not surprisingly, if an SSO ignores its policy, members will too. ${ }^{295}$ And SSOs that enforce their IP rules against some members while giving others a free ride will not only undermine the credibility of those rules, but may also subject themselves to antitrust risks. ${ }^{296}$ If an SSO plans to treat different members differently-for example, by holding proponents of a standard to a different level of scrutiny than other members-it needs to make such a policy clear at the outset and make sure that it is applied neutrally. These concerns are particularly great when the SSO itself is run by market participants rather than neutral third parties, since market participants have an incentive to discriminate against their competitors.

\section{Eschew Disclosure-Only Policies}

Some SSOs require disclosure; others require licensing. Some require both disclosure and licensing, and some require neither. It strikes me as

293. On the importance of representation by affected parties and fair processes, see Maher, supra note 22 , at $40-44$.

294. See supra Part III.A.I (discussing the enforceability of organizational bylaws under contract law).

295. For example, the IETF nominally requires IP owners to specify the terms on which they agree to license their patents, but no one actually does so. Conversation with Robert Barr, supra note 289. Since the IETF has never sanctioned anyone for noncompliance, there is little incentive to specify terms in the future.

296. For a discussion of group boycott liability, see Northwest Wholesale Stationers v. Pacific Stationery \& Printing, 472 U.S. 284, 296 (I985); II HovenKAMP, ANTITRUST Law 9 ff I901-08 (1999). In the context of SSOs, see Lemley, Internet Standardization, supra note 11, at 1083-86. 
largely futile to require members to disclose their IP rights without requiring any sort of licensing. ${ }^{297}$ While disclosure does give SSOs information about what proprietary rights are out there, that information is notably incomplete. It does not include the IP rights of nonmembers. Because most SSOs do not require their members to search their files for relevant patents, ${ }^{298}$ it doesn't even guarantee that members will actually disclose all their IP rights. ${ }^{299}$ Requiring disclosure without licensing also triggers antitrust problems, as cases like Dell Computer and Rambus demonstrate. ${ }^{300}$ All these problems largely disappear if the SSO imposes a licensing requirement, since nondisclosure is a successful anticompetitive strategy only if the IP owner can use its IP rights to hold up users of the standard.

Even when IP rights are properly disclosed, requiring disclosure without licensing creates a conundrum for the members of an SSO. Members have two choices in such a case: adopt the standard despite the IP right or reject the standard to avoid the effect of the IP right. In the former case, the disclosure obligation hasn't helped the members avoid the effect of the IP right at all. Indeed, they may actually be worse off, since they are now on notice that the IP owner has IP that rights cover a standard they intend to use. ${ }^{301}$ In the latter case, the SSO may have left itself vulnerable to antitrust attack for rejecting a proposed standard solely because it was covered by IP rights. Whether or not such an antitrust claim is well-grounded, ${ }^{302}$ the SSO is effectively behaving ex post as if it requires royalty-free licensing, and would almost certainly be better off committing to openness at the outset.

297. A few SSOs require disclosure but not licensing. See supra Part Il.B. Further, Janice Mueller has advocated just such a system. See Mueller, Misuse, supra note 8 .

298. See supra Part II.B (showing that only four out of twenty-four SSOs that require disclosure impose a search obligation).

299. See Schallop, supra note I1, at 232-33 (noting the uncertain scope of disclosure requirements).

300. See supra notes 149-60 and accompanying text (discussing these cases).

30I. This notice will likely make them willful infringers should they use the standard without first negotiating a license from the IP owner. See, e.g., Johns Hopkins Univ. v. Cellpro, Inc., 152 F.3d 1342 (Fed. Cir. 1998). Willful infringement can lead to an increased award of damages. 35 U.S.C. $\$ 284$ (2000); Embrex, Inc. v. Serv. Eng'g. Corp., 216 F.3d 1343, 1347 (Fed. Cir. 2000).

302. In In re American Soc'y of Sanitary Engineering, 106 F.T.C. 324, 328-29 (1985), the FTC concluded that the Society violated the antitrust laws by refusing to consider patented tcchnology as a standard. That case did not involve an exclusive choice of an interface standard, and it isn't clear that its reasoning is applicable to standards of the sort 1 have talked about here. But the DOJ has pursued at least one similar claim in the telecommunications sector. In a series of negotiations regarding rules promulgated by ETSI, the United States put substantial pressure on ETSI to back down from its original rule requiring disclosure and nondiscriminatory licensing of member IP rights embodied in ETSl standards. See Lemley, Internet Standardization, supra note 11, at I089 n.202. To be sure, this approach has precedent in some earlier U.S. cases condemning patent pools and cross licenses. See United States v. New Wrinkle, Inc., 342 U.S. 371 (1952). Further, there were apparently some legitimate complaints about the reciprocity of the ETSI licensing provisions. See Prins \& Schiessl, supra note 232. Still, it is surprising that an SSO rule that appears likely to facilitate competition was instead challenged as impeding it. 
Disclosure is much less important if members have already committed to license their IP rights, since a licensing obligation should apply to IP whether or not it is disclosed. ${ }^{303}$ Nonetheless, disclosure may be useful insofar as it makes clear to SSOs what the consequences of adopting a standard will be. ${ }^{304}$ But even if disclosure is desirable, most SSO IP rules do little to make sure it occurs. To promote disclosure, one idea is to give members incentives to search for and disclose their IP rights. For example, an SSO might adopt a rule that either requires undisclosed IP rights to be licensed on a royalty-free basis or at least caps the royalties that can be charged on undisclosed IP rights. There is some economic literature suggesting that such a "penalty default" will efficiently induce members to disclose information of which they are aware or could cheaply become aware. ${ }^{305}$ Imposing such a rule will likely induce disclosure, though it may create the opposite problem: overdisclosure..$^{306}$

\section{Decide Where Your Organization Falls on the Open-Closed Continuum}

"Open" standards are trendy. Unfortunately, like "open" source code ${ }^{307}$ there are various definitions of open standards. As a result, SSOs may be tempted to claim they are open when they aren't, to be open for some purposes but closed for others, or even to encourage openness

303. Updegrove finds encouraging signs that companies are moving towards accepting SSO licensing rules. Updegrove, supra note 11, at 7.

304. One limit on the value of disclosure concerns timing. Because most disclosure policies merely require disclosure at the meeting at which the standard will be voted on, SSOs that have invested considerable time in promulgating that standard may be reluctant to reconsider it. Disclosure would be more effective if made earlier. However, it is hard to require disclosure until it is clear what the proposed standard will actually look like because IP owners cannot tell if the standard infringes their rights without understanding the specifications. For a discussion of this issue, see Balto \& Prywes, supra note 155 (arguing for early disclosure "when the participant learns that the technology in question is being considered for inclusion in a proposed standard or might be needed to utilize a proposed standard"); Updegrove, supra note 11, at 4.

305. See, e.g., Ayres \& Gertner, Defaults, supra note 261, at 1600; Ayres \& Gertner, Contractual Inefficiency, supra note 261; Ian Ayres \& Robert Gertner, Filling Gaps in Incomplete Contracts: An Economic Theory of Default Rules, 99 YALE L.J. 87, 91 (1989). For a somewhat more skeptical view, see Thomas W. Merrill \& Henry E. Smith, The Property/Contract Interface, 101 Colum. L. Rev. 773, 800-01 (2001).

In an analogous context, the European Union set a sort of "penalty default" of interoperability in its 1991 Software Directive. That directive provides that if a copyright owner in a computer program does not make interface information "readily available," others are permitted to reverse engineer the program to obtain that information. EC Council Directive on the Legal Protection of Computer Programs, Council Directive 91/250, art. 6.1(b), 1991 O.J. (L 122) 42.

306. For a discussion of the overdisclosure problem, see supra Part V1.A.1.

307. On the different kinds of open source, see McGowan, supra note 66; Yochai Benkler, Coase's Penguin (2001) (draft working paper), available at http://www.benkler.org/ CoasesPenguin.PDF. 
without requiring it. ${ }^{308}$ Any of these options would almost certainly be a mistake. There is little to be gained from wishy-washy IP policies that "prefer" but do not inandate nonproprietary standards. Expectations will be raised and dashed; problems will ensue. ${ }^{309}$ An SSO is either committed to making its standards open and nonproprietary or it isn't. If it is, the only way the SSO can further that goal is by requiring assignment or royaltyfree licensing of IP rights that cover the standard.

Only a few SSOs in my study actually committed fully to open standards. ${ }^{310}$ For better or worse, ${ }^{311}$ the vast majority of the SSOs I studied permitted members to own IP rights in the standards they adopt. This does not mean that SSO IP rules were irrelevant for those groups, however. Rather, those SSOs could use IP rules to bargain from a property rule to a liability rule, in Merges's framework. ${ }^{312}$ In so doing, they could avoid potential holdups by members of the SSO, while at the same time ensuring that IP owners were appropriately rewarded with reasonable royalties. SSO IP rules that require only disclosure will not accomplish this; only licensing on reasonable and nondiscriminatory terms guarantees that everyone is able to use the standard while still allowing the IP owner to get paid.

\section{Permit Licenses that Control Fragmentation}

One critique of mandatory licensing is that it may contribute to fragmentation. ${ }^{313}$ Fragmentation is frequently a problem for open standards. If no one owns the standard, users are generally free to modify it in whatever way they see fit. As a result, a single standard may soon "fork" into incompatible versions, defeating the purpose of standardization. This happened with the UNIX operating system, for example. ${ }^{314}$ Others have suggested that open-source software will fragment unless tightly controlled by a central party. ${ }^{315}$ Reserving IP rights is one way to prevent fragmentation,

308. See supra Part II.B (describing SSOs that "discourage" but do not prohibit the ownership of IP rights in a standard).

309. On the other hand, Lisa Bernstein has suggested that unenforceable agreements may serve valuable purposes in close-knit groups in which reputational effects will keep people in lime most of the time. See, e.g., Lisa Bernstein, The Questionable Empirical Basis of Article 2's Incorporation Strategy: A Preliminary Study, 66 U. CHI. L. Rev. 710 (1999); Lisa Bernstein, Merchant Law in a Merchant Court: Rethinking the Code's Search for Immanent Business Norms, 144 U. PA. L. REv. 1765 (1996) [hereinafter Bernstein, Merchant Law].

310. See supra Part II.B.

3I1. I do not take a position in this Article on whether open or closed standards are better for society. For arguments in favor of open standards, see supra note 40 (collecting literature).

3I2. See Merges, Liability Rules, supra note 251.

313. For a discussion of this problem in the standard-setting context, see Gifford, supra note 11, at 15- 17.

314. See Weiser, Networks Unplugged, supra note 35, at 19-21.

315. See, e.g., McGowan, supra note 66, at 275-87 (noting that successful open-source programs such as Linux have been centrally controlled). 
because the $1 \mathrm{P}$ owner can refuse to license incompatible versions. ${ }^{316}$ Conversely, compulsory licensing on reasonable and nondiscriminatory terms might be thought inimical to unified standards.

In fact, however, there are a number of ways SSOs can compel licensing to anyone who wants to use the standard and still prevent fragmentation. Molly van Houweling has suggested the creation of trusted third parties to hold IP rights in standards, with a mandate to permit anyone to use the standard but to prevent forking. ${ }^{317}$ At least one SSO requires that members assign their IP rights to the SSO, permitting the SSO to serve in effect as the trusted third party. ${ }^{318}$ The most obvious solution, however, is by contract. Reasonable and nondiscriminatory terms are generally thought to refer to royalty rates, but there is no reason an IP owner cannot require compatibility with an existing set of protocols as a condition of the license. Reasonable and nondiscriminatory licensing with such a term gives an IP owner the best of both worlds: the IP owner can control the technological development of a standard, but cannot prevent anyone from implementing that standard in a compliant way. And because a license can compel adherence to a particular set of protocols without demanding a royalty or otherwise restricting use, a nondiscriminatory licensing provision of this sort will work both for open source and proprietary standards.

\section{Give Content to the Reasonable and Nondiscriminatory Licensing Requirement}

It is all well and good to propose that SSOs require licensing on reasonable and nondiscriminatory terms. But without some idea of what those terms are, reasonable and nondiscriminatory licensing loses much of its meaning. ${ }^{319}$ Virtually no SSO specifies the terms on which licenses must be granted beyond the vagne requirement that they be "reasonable" and

316. Sun did this with Java and ultimately prevented Microsoft from selling a polluted version of Java. See Sun Microsystems, Inc., v. Microsoft Corp., 87 F. Supp. 2d 992 (N.D. Cal. 2000). To maintain its IP rights, Sun had to withdraw the Java standard from ISO. See, e.g., David P. Hamilton, Sun Plans to Avoid Alleged Hurdles by Microsoft to Get Java Standardized, WALL ST. J., May 7, 1999, at B7. For an endorsement of this approach, see Schallop, supra note 1I, at 262-71.

Indeed, as some have noted, the open-source movement itself relies on an implicit reservation of IP rights by a central coordinator. See Gomulkiewicz, supra note 66; McGowan, supra note 66.

317. Van Houweling, supra note 40.

318. That SSO is RosettaNet. See infra Appendix. Assignment of IP rights to the SSO may create other problems, however. First, the transfer of the rights is an asset acquisition subject to review under section 7 of the Clayton Act, I5 U.S.C. § I8 (2000), and could present antitrust problems if the SSO's standard is likely to dominate a market. See, e.g., 1 HovenKAMP ET AL., supra note $81, \S 14.2$ (b). Second, IP owners may be reluctant to assign their rights, particularly where the IP has uses both within and outside a proposed standard.

319. As Richard Epstein put it in objecting to statutory compulsory licenses in patent law, "[t]he term 'reasonable' does not begin to unpack the question of what fees should be charged or why." Richard Epstein, Steady the Course: Property Rights in Genetic Material 37 (Mar. 15, 2002) (draft workiug paper, on file with author). 
"nondiscriminatory." Indeed, some SSOs expressly forbid discussion of such issues when a standard is under consideration, presumably for fear of antitrust liability. ${ }^{320}$ Further, private licenses are normally confidential. ${ }^{321}$ The result is uncertainty over the cost and scope of patent licenses that may not prove much better than having no policy at all..$^{322}$

One solution to this problem is to have the SSO specify the royalty that will be charged for each IP right. But if "reasonable and nondiscriminatory" without more is too amorphous, specifying the royalty in advance is likely to be too rigid. Patents differ in their likely validity, their importance to the standard, and the ease with which they can be designed around. Further, standards differ in their importance and the price that can be charged for products or components that incorporate the standard. As a result, "one size fits all" is unlikcly to work very well for patent licenses. Indeed, it may have the perverse result of encouraging members to list as many patents as possible that are conceivably relevant to a standard, hoping to increase their royalty rate through sheer quantity without any reference to quality. ${ }^{323}$

I think there is middle ground between complete specification of royalties and abdication of all responsibility for determining them. In particular, there are several things that SSOs can do to help smooth the process of determining what royalties are reasonable and nondiscriminatory. First, SSOs could require members who assert patents to make available to others a copy of all their licenses involving the patent. This would help potential licensees to ensure that the proffered licenses really were nondiscriminatory. ${ }^{324}$ Second, SSOs could give some content to the nondiscrimination requirement, for example by specifying whether royalty rates must be identical for all parties, or whether potential licensees in different situations may be treated differently. ${ }^{325}$ One organization has even gone

320. See IEEE, Understanding Patent Issues During IEEE Standards Development, at http://standards.ieee.org/board/pat/guide.html (last modified Dec. 13, 2001) (stating that subjects such as how a patent should be licensed "are not appropriate topics for discussion in a standards developing committee").

321. See Bekkers \& Liotard, supra note 96 , at 119 ("Licensing agreements are usually treated as highly confidentiaI ....").

322. Not surprisingly, members have begun to litigate the reasonableness of royalty rates set in the standards context. For an example involving Motorola and the 1TU V.34 modem standard, see Shapiro, Competition or Collusion, supra note 268, at 96-97. See also Intersil Corp. v. Proxim, Inc., Civ. No. 01-266 (D. Del. filed Apr. 24, 2001) (alleging that patentee's offer to license a patent covered by an SSO IP rule was unreasonable and a "sham").

323. My conversation with the general counsel of one Fortune 500 company suggests that many patent owners are starting to do just this-overdisclosing patents to try to increase their royalty stream.

324. Requiring a "Most Favored Nation" clause in the licenses could accomplish the same thing.

325. Three likely circumstances in which licensees might be treated differently are (1) where one licensee also owns IP that could be cross-licensed, and the other does not, (2) where the licensees compete in different fields of use, and (3) where some licensees are for-profit and others nonprofit. See Feldman et al., supra note 11, at 114-15. In addition, IP owners might reasonably want to reserve the right to refuse to license to those who later sue them for infringement of a different IP right. One 
so far as to threaten to withdraw a standard where the patentee refused to license its IP except on terms the organization considered unreasonable..$^{326}$ Third, SSOs might be particularly motivated to prevent certain kinds of restrictive nonprice license terms such as grantback clauses and noncompetition agreements. ${ }^{327} \mathrm{On}$ the other hand, they may want to permit reciprocal dealing requirements, so that patentees who submit a standard do not precommit to license their patents in the standard, only to find themselves without a good bargaining chip when sued by nonmembers with their own patents. Fourth, SSOs might set up some means of dispute resolution within the organization to help resolve royalty disagreements. ${ }^{328}$ Resolving reasonable royalty disputes within the SSO will almost certainly be quicker and cheaper than resorting to the courts. It may also permit the disputants to take advantage of the industry expertise that many SSOs have. ${ }^{329}$ Existing groups like ASCAP and BMI may have experience in arbitrating royalty disputes among members that SSOs could draw upon. ${ }^{330}$ Finally, to prevent any dispute-resolution mechanism from being overrun by frivolous claims, SSOs should develop some mechanisin for distinguishing IP that is truly necessary to the operation of the standard from IP that is peripheral. One possibility is to create an administrative sanction for baseless royalty claims.

ln the absence of any private dispute-resolution mechanisin, the task of determining what royalties are reasonable and nondiscriminatory will fall to the courts. This isn't necessarily a bad thing. Courts have a fair bit of experience with determining reasonable royalties in the patent context, having done so in a large number of patent damages cases. ${ }^{331}$ In making

risk of giving up IP rights is the possibility that an IP owner will license its IP to the world, only to find itself the victim of a holdup by another $\mathrm{IP}$ owner. Maintaining the threat of patent enforcement may permit the parties to cross-license in such a circumstance.

326. See Andrew Orlowski, No More JPEGs-ISO to Withdraw Image Standard, The Reglster, July 23, 2002.

327. For a discussion, see Scott K. Peterson, Patents and Standard-Setting Processes, at http://www.ftc.gov/opp/intellect/020418scottkpeterson.pdf (Apr. I8, 2002).

328. See also Balto \& Prywes, supra note 155 (making this suggestion). One SSO, BSI, leaves this responsibility to the British patent office, in accordance with U.K. law. See infra Appendix.

329. An alternative approach, resort to a standard arbitration agreement with an existing provider, may be simpler to administer, but lacks the benefit of technical expertise. Krechmer suggests an intermediate approach, that WIPO set up an arbitration group specializing in standards conflicts. Krechmer, supra note 6, at 5 .

330. By contrast, ASCAP external licensing policies aren't a good analogy for SSOs, because unlike SSOs ASCAP's interests are asymmetric: they represent only copyright holders, and therefore set policies designed to maximize revenue for members at the expense of nonmembers rather than achieve the optimal social outcome.

331. The patent statute requires that damages include lost profits if possible, but in no event less than a reasonable royalty. 35 U.S.C. $\S 284(2000)$. As a practical matter, however, lost profits are difficult to prove, and many cases involve calculation of a reasonable royalty. See 7 Donal. S. Chisum, Patent LAW $\S 20.01$ (2002). Courts use a multi-factor test to determine the appropriate royalty. See Georgia-Pacific Corp. v. U.S. Plywood, Inc., 318 F. Supp. 11 I6 (S.D.N.Y. I970). For a general discussion of patent remedies, see Roger D. Blair \& Thomas F. Cotter, An Economic Analysis 
this determination, courts should put some emphasis on the requirement that the royalty be "reasonable" in commercial and technological context. ${ }^{332}$ If courts do not impose some limits, IP owners could satisfy their reasonable and nondiscriminatory obligation by setting an intentionally outrageous price for a license. This would effectively vitiate the reasonableness obligation. It would also reinstate the double-marginalization problem that the SSO IP rule purports to elimmate. Properly applied, the reasonable and nondiscriminatory licensing requirement will give greater rewvards to more important rights, while making sure that no IP owner can block the implementation of a standard by "licensing" only at an exorbitant price.

\section{Require Members to Evaluate and Comply with the Standard-Setting Organization's Policy}

As this Article has made clear, SSO IP rules should not be taken lightly by members. IP owners who join an SSO are committing themselves to important contractual obligations. In some cases they may have to give up their IP rights altogether, and, in any event, they generally are agreeing to give up their right to injunctive relief and extraordinary damages. In other circumstances, they are committing to a policy of disclosure that, if not followed, can leave the IP owner liable for fraud or antitrust violations. Given the gravity of these commitments, members should not jom an SSO without thinking about the IP consequences. This is particularly true because of the tendency of companies in the telecommunications and computer fields to join many different SSOs with often overlapping mandates. IP owners that belong to many different SSOs might find theinselves bound to the most restrictive IP policy of all the SSOs they joined.

SSO members need an IP compliance policy. This policy should have two different components. First, companies should think long and hard about whether they really want to belong to a particular SSO. Part of that calculus must be the effect of inembership on the company's IP rights. ${ }^{333}$ Companies should have lawyers review the IP policy, determining what IP is covered, what search and disclosure obligations the company must undertake, what licenses they will commit to, and whether the company can withdraw from the SSO rather than forgo its IP rights. In rare

of Damages Rules in Intellectual Property Law, 39 WM. \& MARY L. Rev. 1585 (1998); Roger D. Blair \& Thomas F. Cotter, Rethinking Patent Damages, 10 Tex. INTELL. PRoP. L.J. 1 (2002).

332. Carl Shapiro suggests that the royalty set should be one that is reasonable ex ante, before the standard is selected, not one that might be obtainable after the industry has been locked into the patented standard. See Shapiro, Competition or Collusion, supra note 268, at 96; accord Feldman et al., supra note 11, at 114; Patterson, supra note 11 . This seems correct. A reasonable royalty should consider the available alternatives at the time the decision was made to adopt the standard, not the value that an IP owner might be able to extort by virtue of the SSO's adoption of that standard.

333. This may be balanced by a corresponding benefit: access to the $1 P$ of other members, particularly if the SSO compels licensing only to its members. 
circumstances a company might be well advised to avoid joining an SSO altogether because of its IP policy. In other cases the policy may not be fully thought out, and the SSO may be open to changing its policy. ${ }^{334}$ Even if the company decides that the benefits of joining the SSO outweigh any loss of IP rights, that decision should be made by people in the company who are aware of the issues, and not simply by any employee who decides to join an SSO.

Second, companies must ensure that they comply with the rules of any SSO that they join. The experience of Dell, Sun, Rambus, Unocal, and others strongly suggests that companies should bend over backwards to disclose IP rights in doubtful cases. But they can't do so unless someone in a position to know about IP rights - almost certainly a lawyer or IP manager-is involved in the standard-setting process in at least a supervisory capacity. Companies must also ensure that they comply with any other obligations, such as a requireinent that they disclose their licenses of covered patents.

It isn't at all clear that most companies take participation in SSOs very seriously today. My suggestions might be thought to raise the stakes in an impractical way. After all, who wants to send lawyers to standardsetting meetings? But companies are making serious commitments by joining such SSOs, and they may come to regret it if they do not recognize the importance of their participation in these SSOs. Taking participation more seriously may cause soine members to drop out of some SSOs altogether, a result that might seem to impede standardization. But if companies drop out because they realize the costs as well as the benefits of participation, we should be happy that they have made a rational decision with full information. Those who would rely on a system of private ordering should expect no less from the marketplace.

\section{B. Implications for Policy Makers}

If the stylized model I offered in Part V.A is accurate, government should not need to do much about SSO IP rules. Rather, it should sit back and enjoy the benefits of efficient private ordering in the shadow of the IP system. In the rather messier real world, however, there are some legal and policy implications of my arguments.

First, like most forms of private ordering, SSO IP rules cannot serve their intended purpose unless they are enforceable in court. ${ }^{335}$ Courts must

334. Two SSOs that have at least considered changing their IP policies in response to member pressure are the IETF and the W3C. See supra notes 7-8 and accompanying text (discussing these cases).

335. Peggy Radin and Polk Wagner recently emphasized the point legal realists taught us long ago: even "private" systems of enforcement depend ultimately on the coercive power of the courts. See Radin \& Wagner, supra note 66. 
be willing to treat SSO IP rules as enforceable agreements. ${ }^{336}$ As we have seen, ${ }^{337}$ though, enforcement as a matter of contract law may not be enough. Courts must also apply the IP doctrines of implied license and equitable estoppel in appropriate circumstances to prevent IP owners from avoiding their contractual obligations. Both contract and IP precedent provide a mechanism for enforcing SSO IP rules; courts should not hesitate to do so.

Second, laws should not impede the creation of these private arrangements. I have argued elsewhere that SSOs themselves generally should not be held to violate the antitrust laws. ${ }^{338}$ One implication of this Article is that courts should be extremely reluctant to condemn SSO IP rules as anticompetitive. There are occasional circumstances in which SSOs act as a front for a cartel. ${ }^{339}$ But, while it is possible for an SSO to restrict competition in innovative markets by systematically undervaluing IP rights, ${ }^{340}$ SSO IP rules can also serve valuable procompetitive purposes by clearing overlapping IP rights, particularly in network markets where standardization is important. Antitrust law should be extremely reluctant to

There are forms of private ordering that do not depend on state coercion, notably social norms. The economic literature on social norms is voluminous. See, e.g., ROBERT C. ELLICKSON, ORDER WITHOUT LAw: How Neighbors Setrle Disputes (1991); Lisa Bernstein, Merchant Law, supra note 309; Lisa Bernstein, Social Norms and Default Rules Analysis, 3 S. CAL. INTERDISC. L.J. 59 (1993); Lisa Bemstein, Opting Out of the Legal System: Extralegal Contractual Relations in the Diamond Industry, 21 J. Legal Stud. 115 (1992); Robert D. Cooter, Decentralized Law for a Complex Economy: The Structural Approach to Adjudicating the New Law Merchant, 144 U. PA. L. Rev. 1643 (1996); Robert D. Cooter, The Theory of Market Modernization of Law, 16 INT'L REv. L. \& EcoN. 141 (1996); Robert D. Cooter, Structural Adjudication and the New Law Merchant: A Model of Decentralized Law, 14 INT'L Rev. L. \& Econ. 215 (1994); Robert D. Cooter, Against Legal Centrism, 81 CALIF. L. Rev. 417 (1993); Avner Greif, Reputation and Coalitions in Medieval Trade: Evidence on the Maghribi Traders, in Reputation (1989); Peter H. Huang \& Ho-Mou Wu, More Order Without More Law: A Theory of Social Norms and Organizational Cultures, 10 J.L. EcoN. \& ORG. 390 (1994); Avery Katz, Taking Private Ordering Seriously, 144 U. PA. L. Rev. 1745 (1996); Jody S. Kraus, Legal Design and the Evolution of Commercial Norms, 26 J. LeGal Stud. 377 (1997); Richard H. McAdams, The Origin, Development, and Regulation of Norms, 96 MrCH. L. Rev. 338 (1997); Richard H. McAdams, Comment, Accounting for Norms, 1997 Wis. L. Rev. 625; Randal C. Picker, Simplc Games in a Complex World: A Generative Approach to the Adoption of Norms, 64 U. CHI. L. REv. 1225 (1997). For more critical analyses, see David Chamy, Illusions of a Spontaneous Order: "Norms" in Contractual Relationships, 144 U. PA. L. REv. 1841 (1996); Lawrence Lessig, Social Meaning and Social Norms, 144 U. PA. L. REv. 2181 (1996); Eric A. Posner, Law, Economics, and Inefficient Norms, 144 U. PA. L. REv. 1697 (1996). A full discussion of social norms as a regulatory system is beyond the scope of this paper. In the context of SSO IP nules, informal social sanctions are unlikely to prevent an IP owner from enforcing its rights. Thus, Bernstein's conclusion that the law should not enforce private norms does not seem applicable here. Bernstein, Merchant Law, supra note 309, at 1765. Still, it is possible that the organizational rule itself will, if internalized sufficiently, encourage more reasonable licensing practices by companies.

336. Accord Maher, supra note 22.

337. See supra Part III.A (discussing limitations of contract enforcement).

338. See Lemley, Internet Standardization, supra note 11, at 1080; accord Shapiro, Thicket, supra note 11 , at 28 .

339. For a full discussion, see 2 HovenKAMP ET AL., supra note 34 , ch. 35.

340. See id. $\$ 35.6$ (discussing antitrust problems of this sort); see also supra Parts IV.B \& IV.C. 
interfere with this process to avoid chilling the creation of private liability rules in the patent system. One way to achieve this is to create a limited safe harbor for SSOs that agree on IP rules. ${ }^{341}$ Whether under a safe harbor or under the rule of reason, SSOs should generally be protected from liability even if they take an active role in determining what a reasonable and nondiscriminatory royalty should be, so long as they apply a fair process set ex ante. ${ }^{342}$

Third, the government acts not only as a regulator but also as a market participant. Several of the SSOs I have studied are either run by the government, have the government as a member, or otherwise have some federal imprimatur. The government can support the development of appropriate IP rules in SSOs not only through legislation, but also by implementing such rules in its own SSOs and advocating their use in SSOs in which it participates. Whether the government should advocate a particular view is another matter. There may be reasons for the government not to take sides in the open-closed debate, for example. ${ }^{343}$ The government is entitled to act in its own interest as a market participant, just as any other large player would be. But the participation of the government even as a market participant highlights the extent to which private ordering in SSOs is imbued with a quasi-public character.

Finally, contract, IP, and antitrust law can all play valuable roles in policing the process of private ordering through SSOs. For example, private agreements to convert patent law's property rules into liability rules are efficient only if the parties to the agreement have accurate information and a full opportunity to decide whether they want to agree. Contract and IP law can help ensure this transparency by enforcing only SSO IP rules that meet certain threshold criteria. And although antitrust law does not normally impose a requirement of minimum process for private decisions, ${ }^{344}$ it can give some teeth to disclosure obligations by policing efforts

341. Such a bill is in the works at the time of this writing. The legislation, sponsored by Reps. Sensenbrenner and Conyers, would modify the National Cooperative Research and Production Act, 15 U.S.C. $\$ 4301$ (2000), to include SSOs in the scope of its partial safe harbor. See also Updegrove, supra note 11 , at 10 (endorsing this approach).

342. See Patterson, supra note 11, at 4-5 (proposing that SSOs be thought of as "owners" of the standard with the power to negotiate collectively on behalf of their members' interests); see also Balto \& Prywes, supra note 155 (proposing to permit SSOs to encourage discussion of licensing terms).

343. The government has endorsed open standards in some settings, though its position on the issue can be criticized as inconsistent. See Mark A. Lemley, Standardizing Government StandardSetting Policy for Electronic Commerce, 14 BERKELEY TECH. L.J. 745 (1999). For an argument that the government should be more involved in pushing these decisions, see Weiser, Internet Governance, supra note 11.

344. See Northwest Wholesale Stationers, Inc. v. Pacific Stationery \& Printing Co., 472 U.S. 284, 293 (I985) ("[T] he antitrust laws do not themselves impose on joint ventures a requirement of process."). 
to achieve market dominance through "gaming" the standard-setting system. ${ }^{345}$

In short, the role of the law in governing SSO IP rules should be limited to ensuring that SSO IP rules are fair and to enforcing them when necessary. Beyond that, the best thing courts can do is stay out of the way. Thus, the implications of SSO IP rules for policy makers at one level are quite limited. But at another level, SSO IP rules have important implications for IP policy, particularly patent policy. Reform of the patent system must take account of both industry-specific variations in how patents affect innovation and how markets respond to patent rights. SSO IP rules dramatically affect both areas. If SSOs provide a way for companies to ameliorate the anticompetitive risks of patents in certain industries, they may make the patent system as a whole much more efficient than it otherwise would be. They may also reduce the need for an industry-specific patent system. ${ }^{346}$ In any event, it should be clear that we cannot design an optimal patent policy without paying close attention to how patents are actually used and licensed in practice. SSOs are a large piece of that puzzle.

\section{CONCLUSIONS}

The interaction between IP and innovation is a complex one. That interaction isn't simply a function of the traditional theory of IP as a mechanism for maintaining market exclusivity. Rather, any study of IP and innovation must take account of how IP is used in the real world. Previous work has shown that the effect of IP differs greatly from industry to industry. For example, patents create most of their problems in the telecommunications, computer, and Internet industries, where they are most likely to overlap and block the development of necessary improvements.

Fortunately, SSOs, which tend to exist in precisely those industries, provide a way for private parties to contract around the effect of these overlapping IP rights. SSO members are effectively contracting in the shadow of IP law, bargaining from an mefficiently powerful set of property rules to a world in which IP rights are either removed from the picture entirely or are licensed in advance on standardized terms. SSO IP rules are thus a partial market solution to a problem created by overbroad IP protection.

SSO IP rules are also an example of what one might call "messy private ordermg. ${ }^{347}$ Legal theorists too often tend to exalt private ordering

345. See supra Part III.C.I (discussing such situations).

346. On the growth of such a system, see Dan L. Burk \& Mark A. Lemley, Is Patent Law Technology-Specific? 17 BERKELEY TECH. L.J. (forthcoming 2002). On its importance, see Burk \& Lemley, Policy Levers, supra note 265.

347. The classic treatment of the internal workings of SSOs is SUZANNE K. SCHMidT \& Raymund Werle, CoORdinating Technology: Studies IN THE INTERNational Standardization of Telecommunications (MIT Press 1998). Cf. Robert J. Aiken \& John S. 
as perfect and denigrate public rules as incompetent, corrupt, or both. My empirical exploration does not reveal a perfectly functioning contractual system, a fact that advocates of private ordering will have to come to terms with. But it is a system that may be good enough for the real world. It is also a system that can be improved by increased attention to process concerns, something I recommend in this Article.

My overall conclusion is an optimistic one. Messy private ordering by SSOs may or may not be better for innovation than an optimally designed IP system. But it is almost certainly better than the problematic IP system that we actually have. By ameliorating some of the threats that overbroad and overlapping patents pose for innovation, SSO IP rules help the IP system do what it was originally designed to do: promote innovation. 


\section{APPENDIX}

Standard-Setting Organization Intellectual Property Policies ${ }^{348}$

\begin{tabular}{|c|c|c|c|c|c|}
\hline SSO & Policy? & Disclosnre? & Search? & $\begin{array}{l}\text { Can } \\
\text { Standard } \\
\text { Inclnde IP? }\end{array}$ & Licensing Provisions \\
\hline W3 $3 C^{239}$ & $\mathrm{P}, \mathrm{TM},(\mathrm{C}$ & $\mathrm{Yes}^{350}$ & No & Yes & $\begin{array}{l}\text { Royalty-free license requested } \\
\text { but not required; RAND as } \\
\text { alternative. }\end{array}$ \\
\hline $120 \mathrm{SIG}^{352}$ & $\mathrm{P}, \mathrm{TM}$ & No & No & $\mathrm{Yes}^{333}$ & Royalty-free license required \\
\hline $\begin{array}{l}\text { Wired for } \\
\text { Management }\end{array}$ & $P$ & No & No & $\mathrm{Yes}^{355}$ & $\begin{array}{l}\text { Royalty-free license required } \\
\text { for necessary claims only }\end{array}$ \\
\hline IETF $^{256}$ & $\mathrm{P}, \mathrm{C}$ & Yes & No & $\mathrm{Yes}^{357}$ & $\begin{array}{l}\text { Royalty-free license as to } \mathbb{C} \text {; } \\
\text { RAND to all users as to P; } \\
\text { terms must be specified }\end{array}$ \\
\hline IEEE $^{399}$ & $\mathrm{P}, \mathrm{TM}, \mathbb{C}$ & Yes & No & Yes & $\begin{array}{l}\text { RAND; terms may not be } \\
\text { discussed in group meetings }\end{array}$ \\
\hline RosettaNet $^{339}$ & All IP & Yes & No & $\mathrm{Yes}^{360}$ & $\begin{array}{l}\text { Business method Ps are li- } \\
\text { censed royalty-free }\end{array}$ \\
\hline $\mathrm{IMC}^{361}$ & None & $\mathrm{N} / \mathrm{A}$ & N/A & N/A & N/A \\
\hline $\mathrm{OMG}^{3 / 2}$ & All IP & No & No & No & Ownership of IP not allowed \\
\hline $\mathrm{OBI}^{3+3}$ & $\begin{array}{l}\text { Rights } \\
\text { reserved }^{364}\end{array}$ & N/A & N/A & N/A & N/A \\
\hline $\mathrm{ITU}^{3 / 3}$ & $P$ & $\begin{array}{l}\text { Yes; } \\
\text { mciudes } \\
\text { pendimg P } \\
\end{array}$ & No & Yes & $\begin{array}{l}\text { RAND; no "monopolistic } \\
\text { abuse" }\end{array}$ \\
\hline $\mathrm{ISO}^{3 / 2}$ & $\mathrm{P}, \mathrm{TM}, \odot$ & Yes & No & Yes & $\begin{array}{l}\text { P must be given up or RAND } \\
\text { required; nonexclusive } \overparen{ } \\
\text { license to ISO; no TM rule }\end{array}$ \\
\hline FSTC $^{3 \times 7}$ & None & N/A & N/A & N/A & N/A \\
\hline $\mathrm{N} \mathrm{ST}^{2 \times 4}$ & $P$ & Yes & Yes & Yes & Incorporates ANSI rules \\
\hline $\mathrm{ANSl}^{3 * \prime}$ & $\mathrm{P}, \mathrm{TM}$ & $\mathrm{No}^{370}$ & No & Maybe $^{371}$ & $\begin{array}{l}\text { RAND; ANSI will review } \\
\text { claims of unreasonableness }\end{array}$ \\
\hline $\mathrm{ETSl}^{372}$ & $\begin{array}{l}\text { P, utility } \\
\text { model, } \\
\text { designs }\end{array}$ & Yes & Depends $^{373}$ & Maybe $^{374}$ & $\begin{array}{l}\text { RAND; irrevocable; but } \\
\text { standard may be adopted even } \\
\text { if patentee refuses to license. } \mathbb{C} \\
\text { and TS are transferred to } \\
\text { ETS }^{375}\end{array}$ \\
\hline $\mathrm{BSI}^{17 \mathrm{th}}$ & $\mathrm{P}$ & No & No & Yes & $\begin{array}{l}\text { Users licensed as of right; } \\
\text { British patent office to settle } \\
\text { disputes as to terms }{ }^{37}\end{array}$ \\
\hline ATM Forum & $\mathrm{P}, \mathrm{TM},(\mathrm{C}$ & $\begin{array}{l}\text { Yes; includes } \\
\text { only published } \\
\text { applications }\end{array}$ & No & $\mathrm{Yes}^{378}$ & $\begin{array}{l}\text { Royalty-free license as to } \mathbb{C} \text {; } \\
\text { RAND licensing of } P \text { or a } \\
\text { written refusal to do so }\end{array}$ \\
\hline
\end{tabular}




\begin{tabular}{|c|c|c|c|c|c|}
\hline SSO & Policy? & Disclosure? & Search? & $\begin{array}{l}\text { Can } \\
\text { Standard } \\
\text { Include IP? }\end{array}$ & Licensing Provisions \\
\hline $\begin{array}{l}\text { CEN/ } \\
\text { CENELEC }\end{array}$ & $\mathrm{P}$ & Yes & No & Maybe $^{379}$ & $\begin{array}{l}\text { RAND to entire world required } \\
\text { or standard is withdrawn }\end{array}$ \\
\hline Parlay Group & $P$ & Yes & No & Yes & $\begin{array}{l}\text { RAND to Parlay and other } \\
\text { members }\end{array}$ \\
\hline $\mathrm{OGC}^{381}$ & None & N/A & N/A & N/A & N/A \\
\hline $\begin{array}{l}\text { Open Mobile } \\
\text { Alliance (pre- } \\
\text { viously WAP } \\
\text { Forum) }\end{array}$ & $\mathrm{P}, \mathbb{C}$ & $\begin{array}{l}\text { Yes; } \\
\text { includes some } \\
\text { pending } \\
\text { applications }{ }^{382}\end{array}$ & No & Yes & RAND required \\
\hline DMTF $^{383}$ & $\mathrm{P}$ & No & No & Yes & $\begin{array}{l}\text { RAND required or Board } \\
\text { approval }\end{array}$ \\
\hline $\mathrm{MWIF}^{384}$ & All IP & Yes & No & Yes & $\begin{array}{l}\text { Royalty free license or RAND } \\
\text { automatically compelled in the } \\
\text { case of nondisclosure }\end{array}$ \\
\hline $\mathrm{OSGi}^{385}$ & All IP & $\begin{array}{l}\text { Yes, } \\
\text { including } \\
\text { pending claims }\end{array}$ & No & Yes & $\begin{array}{l}\text { RAND required by agreement } \\
\text { to join group }\end{array}$ \\
\hline Open Group ${ }^{386}$ & P, C , TS & Yes & De facto ${ }^{387}$ & Yes & $\begin{array}{l}\text { (C) must be licensed royalty- } \\
\text { free; RAND for P }\end{array}$ \\
\hline $\begin{array}{l}\text { Commer- } \\
\text { ceNet }^{38}\end{array}$ & None & N/A & $\mathrm{N} / \mathrm{A}$ & N/A & N/A \\
\hline $\begin{array}{l}\text { Frame Relay } \\
\text { Forum }\end{array}$ & $\mathrm{P}$ & $\begin{array}{l}\text { Yes; standards } \\
\text { may be re- } \\
\text { voked for non- } \\
\text { disclosure }\end{array}$ & $\begin{array}{l}\text { "Reason- } \\
\text { able" } \\
\text { search } \\
\text { required }\end{array}$ & Yes & RAND $^{389}$ \\
\hline AMI $2^{300}$ & None & $\mathrm{N} / \mathrm{A}$ & $\mathrm{N} / \mathrm{A}$ & N/A & N/A \\
\hline JEITA $^{391}$ & $\begin{array}{l}\text { In } \\
\text { progress }\end{array}$ & N/A & N/A & N/A & N/A \\
\hline ECMA $^{393}$ & $\mathrm{P}$ & $\begin{array}{l}\text { Yes, } \\
\text { including } \\
\text { pending appli- } \\
\text { cations. }\end{array}$ & $\begin{array}{l}\text { Maybe; } \\
\text { "members } \\
\ldots \text {.. will } \\
\text { deter- } \\
\text { mine" IP } \\
\text { rights }\end{array}$ & Yes & $\begin{array}{l}\text { RAND, or the standard will be } \\
\text { cancelled }\end{array}$ \\
\hline $\mathrm{J}_{\text {Consortium }}{ }^{394}$ & All IP & $\begin{array}{l}\text { Disclosure } \\
\text { "encouraged" }\end{array}$ & No & Yes & $\begin{array}{l}\text { RAND, or the standard will be } \\
\text { referred back to Committee for } \\
\text { consideration }\end{array}$ \\
\hline $\mathrm{JEDEC}^{395}$ & $\mathrm{P}$, (C) & $\begin{array}{l}\text { Yes, } \\
\text { including } \\
\text { pending } \\
\text { applications }\end{array}$ & No & Yes & $\begin{array}{l}\text { RAND, or possible withdrawal } \\
\text { of the standard, for } P \text {; permis- } \\
\text { sion for }(\mathcal{C} \text { material }\end{array}$ \\
\hline OASIS $^{396}$ & $\mathrm{P}, \mathbb{C}$ & $\begin{array}{l}\text { Disclosure } \\
\text { "encouraged" }\end{array}$ & No & Yes & RAND \\
\hline
\end{tabular}




\begin{tabular}{|c|c|c|c|c|c|}
\hline SSO & Policy? & Disclosure? & Search? & $\begin{array}{l}\text { Can } \\
\text { Standard } \\
\text { Iuclude IP? }\end{array}$ & Liceusing Provisious \\
\hline PKI Forum, ${ }^{3,97}$ & $\mathrm{P},(\mathrm{C}$ & Yes & No & Yes & $\begin{array}{l}\text { Perpetual royalty-free license } \\
\text { for }(; \text {; RAND for } P\end{array}$ \\
\hline $\begin{array}{l}\text { SDR } \\
\text { Forum }\end{array}$ & $P$ & No & No & Yes & RAND; terms specified \\
\hline $\mathrm{DIN}^{3 ; i}$ & All IP & No & No & $\begin{array}{l}\text { Exceptional } \\
\text { cases }\end{array}$ & $\begin{array}{l}\text { No IP rights permitted; in } \\
\text { "exceptional" cases licensing } \\
\text { on "suitable terms" }\end{array}$ \\
\hline $\mathrm{PICMG}^{4 / 5}$ & None & No & No & Yes & $\begin{array}{l}\text { RAND, in one example of } \\
\text { practice }\end{array}$ \\
\hline $\begin{array}{l}\text { Salutation } \\
\text { Consortium }\end{array}$ & All IP & $\begin{array}{l}\text { Yes, if member } \\
\text { needs third } \\
\text { party permis- } \\
\text { sion to grant } \\
\text { licensing of the } \\
P\end{array}$ & No & Yes & $\begin{array}{l}\text { Royalty-free, nonexclusive, } \\
\text { nonrestricted license of } \odot \text { to } \\
\text { members; RAND for P; manda- } \\
\text { tory cross-licensing clause for } \\
\text { nonmembers }\end{array}$ \\
\hline $\mathrm{SCC}^{253}$ & $P$ & Yes & No & $\begin{array}{l}\text { Yes, if justifi- } \\
\text { able for techni- } \\
\text { cal reasons }\end{array}$ & RAND \\
\hline $\mathrm{SCTE}^{2(\omega)}$ & $P, \odot$ & Yes & No & $\begin{array}{l}\text { Yes, if justified } \\
\text { by technical } \\
\text { reasons }\end{array}$ & RAND for P; free license for $(\widehat{C}$ \\
\hline ATIS $^{4 / 5}$ & $P$ & Yes & No & $\begin{array}{l}\text { Yes, if justified } \\
\text { by technical } \\
\text { reasons }\end{array}$ & RAND \\
\hline $\begin{array}{l}\text { The Global } \\
\text { Platform } \\
\text { Organization }\end{array}$ & All IP & Yes & No & Yes & RAND for $P$; full license for $\odot$ \\
\hline $\mathrm{TIA}^{407}$ & $P$ & Yes & No & $\begin{array}{l}\text { Yes, if justified } \\
\text { for technical } \\
\text { reasons }\end{array}$ & RAND \\
\hline
\end{tabular}

348. In this table, P means patent, TM means trademark, (C) means copyright, TS means trade secret, and RAND means "reasonable and nondiscriminatory licensing."

349. World Wide Web Consortium. See W3C, W3C Intellectual Rights Notice and Legal Disclaimers, at http://www.w3.org/Consortium/Legal/.

350. Under the Feb. 26, 2002 Working Draf, W3C Members who commit to royalty-free licensing need not disclose patents. Patent Policy Working Group Royalty-Free Patent Policy, Working Draft 26 Feb. 2002, § 4, at http://www.w3.org/TR/2002/WD-patent-policy-20020226.

351. Id. "Under this policy, W3C will not approve a Recommendation if it is aware that Essential Claims exist which are not available on Royalty-Free terms." Id. $\$ 1$. While the new W3C policy has royalty-free licensing as a default, there are procedures for excluding specific patents from the overall royalty-free licensing commitment. Thus, the $\mathrm{W} 3 \mathrm{C}$ does not always require royalty-free licensing.

352. Intelligent Input/Output Specification. The I2O SIG ceased operations on October 13, 2000. For archive of files and specifications, see Intelligent-IO.com, Home Page, at http://www.intelligentio.com/.

353. Subject to a royalty-free license. $120 \mathrm{S1G}, I 2 O$ Initiative Agreement (Intelligent I/O Specification) (Version 13 October 1995), available at http://www.i2osig.org/SIG/Agreement.html (last 
visited June 19, 2002). "All . . intellectual property rights . . . shall be govemed by the terms of the Technology Contribution Agreement." Id. $\S 1$ I.1. The Technology Contribution Agreement is attached as Exhibit $\mathrm{E}$ to the $\mathrm{I} 2 \mathrm{O}$ Initiative Agreement.

354. The current specification is at Intel Research \& Development, Wired for Management (WfM), at $\mathrm{http}: / /$ developer.intel.com $/ \mathrm{ia} / \mathrm{wfm} / \mathrm{wfmspecs.htm}$. For a description of the patent policy during the development period, see Intel Research \& Development, Wired for Management (WfM) Baseline 2.0 Specifications Are Available Now!, at http://www.fuw.edu.pl/ jt/Intel-wfmspecs.htm ("Before implementing the Wired for Management Baseline Specification Version 2.0, a royalty-free reciprocal patent license must be signed and retumed to Intel.").

355. Subject to a royalty-free license.

356. The major IP-related request for comments is RFC 2026. Network Working Group, The Internet Standards Process-Revision 3, (S. Bradner, ed.), available at http://www.jetf.org/ $\mathrm{rfc} / \mathrm{ffc} 2026$.txt (last modified Oct. 1996). Within RFC 2026, section 10 is the IP section. It discusses copyright and says that "the owners of any proprietary rights . . grant an unlimited perpetual, nonexclusive, royalty-free, world-wide right and license to the ISOC and the IETF under any copyrights in the contribution." Id. $\S 10.3$.1, point 1 . It also discusses disclosure of proprietary or IP rights that are "reasonably and personally known" to the contributor. $I d$. $\S 10.3 .1$, point 6 . Finally, it discusses the "openly specified, reasonable, non-discriminatory terms" for patent licenses. Some groups (such as the Organization for the Advancement of Structured Information Standards) adopt the IETF standards. Id. $\S 10.3 .2(\mathrm{c})$.

357. See id. $\$ 5$. ("[P]refer unpatented technology, but if the best technology is patented and is available to all at reasonable terms, then incorporation of patented technology is acceptable.").

358. Institute of Electrical and Electronics Engineers. See IEEE-SA, IEEE-SA Standards Board Bylaws, available at http:/standards.ieee.org/guides/bylaws/sect6-7.html\#6 (setting forth the IEEESA's patent policy); IEEE-SA, IEEE-SA Standards Board Operations Manual, available at http://standards.ieee.org/gnides/opman/sect6.html \#6.3 (setting forth operational procedures relating to the patent policy); Id. $\S \S 6.1,6.2$. Copyright is covered under section 6.1 of the Standards Board Operations Manual, and the policy merely states that the working group is responsible to get "written permission to use" copyrighted material prior to submission of the standard. Section 6.2 specifies that trademarks shall not be used to the extent possible but may be used descriptively if necessary. Id. See also IEEE, IEEE-SA Records of IEEE Standards-Related Patents, available at $\mathrm{http}$ ://standards.ieee.org/ $\mathrm{db} /$ patents/index.html (last visited June 20, 2002).

359. RosettaNet develops electronic-business process standards. RosettaNet, RosettaNet Home at http://www.rosettanet.org/.

360. Necessary claims of patents for business methods, business processes, data structure, and data format specifications that are contributed to a standard by their owner are required to be licensed royalty-free. RosettaNet, RosettaNet Intellectual Property Policy, Amended and Restated June II, 2002, available at http://www.rosettanet.org/RosettaNet/Rooms/DisplayPages/LayoutInitial?Container =com.webridge.entity. Entity\%5BO1D\%5B19249BD84B612340945D6E 13C4165C17\%5D\%5D. IP owners grant a royalty-free license to copyrights and give up confidential information in trade secrets. RosettaNet makes no claim on trademarks.

361. Internet Mail Consortium.

362. Object Management Group. See Object Management Group, Home Page, at http://www.omg.org. OMG's policies specify only that "[p]roprietary information shall not be disclosed by any participant. . . . In addition, no information of a secret or proprietary nature shall be made available to the OMG as official documents, and no such documents . . shall be made OMG official documents or forwarded to the membership." Object Management Group, Policies and Procedures of the OMG Technical Process (Version 2.0) (13th Sept. 2001), at http://cgi.omg.org/docs/pp/01-0901.html (last visited June 13,2002). A note within the section suggests that IP is not allowed in OMG standards. Id. $\S 5$.

363. Open Buying on the Internet (OB1) Consortium. OB1, Home Page, at http://www.openbuy.org/ [hereinafter OBI, Home Page]. See, e.g., OBI, By-Laws of the OBI Consortium, $\S 2.7$, available at http://www.openbuy.org/members/bylaws.html [hereinafter By-Laws] (specifying rights in IP). CommerceNet's Research Member Distribution Policy suggests that some research may have different copyright and distribution policies (on file with author). 
364. The OBI has not in fact set a policy regarding IP in its bylaws, but has reserved the right to do so. $O B I$, By-Laws, supra note 363 , $\$ 2.7$.

365. International Telecommunications Union. See International Telecommunications Union, ITU-

$T$ Patent Policy, available at http://www.itu.int/TTU-T/dbase/patent/Patent_Policy.html; see also International Telecommunications Union, About ITU-T TSB Patent Statements Database, available at http://www.itu.int//TU-T/patent/Readme.html; International Telecommunications Union, Patent Database [PaLMS Information Search], available at http://www.itu.int/palms/ITU-R/default.asp.

366. International Organization for Standardization. See ISO Online, Home Page, at http:// www.iso.ch. For a detailed discussion of the ISO standard-setting process, see Lemley \& McGowan, supra note 40, at 753-69. A number of smaller groups (such as the UNICODE Consortium) explicitly adopt ISO/IEC rules. See ISO/IEC Information Technology Task Force, ISO/IEC Directives, Part 1: Procedures for the Technical Work, and ISOIIEC Directives, Part 2: Rules for the Structure and Drafting of International Standards (4th ed. 2001), available at http://isotc.iso.ch/livelink/ livelink/fetch/2000/2489/Ittf_Home/ITTF.htin.

367. Financial Services Technology Consortium. See Financial Services Technology Consortium, Home Page, at http://www.fstc.org. The organization does not appear to have an official policy, but at "Project Lifecycle," it says that FSTC "fosters adoptions" of specifications and protocols by "mov[ing] products to marketplace, keeping IP in public domain or-if patented-available through low-cost licensing." Financial Services Technology Consortium, FSTC Projects, at http://www.fstc.org/ projects/lifecycle.cfm.

368. National Institute of Standards and Technology. See National Institute of Standards and Technology, Hoine Page, at http://www.nist.gov; see also Office of Management and Budget, Federal Participation in the Development and Use of Voluntary Consensus Standards and in Conformity Assessment Activities, Circular No. A-119, Feb. 10, 1998, available at http://www.whitehouse.gov/ omb/circulars/a1 19/aI I9.html; Standards Services Division, Home Page, at http://s.nist.gov/ts/htdocs/ 210/ssd.htm.

369. American National Standards Institute. For a discussion of the ANSI policy, see Robert P. Feldman \& Maura L. Rees, The Effect of Industry Standard Setting on Patent Licensing and Enforcement, IEEE Communications, July 2000, at 112, 113. A number of sinaller technical groups (VITA Standards Organization covering the VME Bus standard) explicitly adopt the ANSI approach.

370. ANSI's website says that ANSI is not responsible for identifying patents. American National Standards Institute, Procedures for the Development and Coordination of American National Standards, \$ 1.2.11.4, at http://www.ansi.org/public/library/std_proc/anspro/due_proc1.html. Earlier sections discuss what happens "if" a patent holder brings the patent to the attention of ANSI, but apparently no section requires that a patent holder do so. The "Guidelines for Implementation ..." say that "[n]either the standards developer submitting a standard for approval nor ANSI" are responsible for identifying patents, but that "[a] standards developer . . . should take steps that it reasonably concludes are sufficient" to meet the patent policy. ANSI Online, Guidelines for Implementation of the ANSI Patent Policy, at http://www.ansi.org/public/library/guides/ppguide.html. The "Possible Procedures" section suggests that individual standards working groups may adopt their own disclosure policies, although not including an obligation to search; or the groups might adopt a promise to license on reasonable and nondiscriminatory terms in lieu of disclosure. Id. $\S 3$.

371. ANSI permits patented standards only if "technical reasons justify this approach." American National Standards Institute, supra note 370, \$ 1.2.11.1.

372. European Telecommunications Standards Institute. For a discussion of ETSI policy, see Johan Verbruggen \& Anna Lorincz, Patents and Technical Standards, 33 IIC-INT'L REv. OF INDUs. Prop. \& COPYRIGHT L. 125 (2002), available at http:/www.ip.mpg.de/Enhanced/Deutsch/ Veroeffentlichungen/IIC-Contents/2002/toc_2_2002.htm.

373. EC policy requires that the patent owner conduct a search unless the standard-setting body commits to do the search itself. See European Commission, Communication on IPRs, fif 4.5.I, 4.5.2.

374. ETSI policy provides that the General Assembly shall refer cases of patent ownership to the EC and EFTA "for their consideration" if the patentee refuses to license on reasonable and nondiscriminatory terms. Verbruggen \& Lorincz, supra note 372, at 15. 
375. ETSI Directives Annex 6. ETSI, if requested, may commission a search. Id. § 6.2. Section 9.I covers copyrights (which vest in ETSI but ETSI will credit other copyrighted works included) and section 10 covers trade secrets (which are treated as nonconfidential if adopted into a standard).

376. British Standards Institute. BSI, Home Page, at http://www.bsi-global.com/index.xalter. See also Verbruggen \& Lorincz, supra note 372 , at 125; British Standard, A StandaRd For Standards: Part i: Guide to the Context, Aims and General Principles, available at http://www.bsi-global.com/StandardsDevelopment/Developed/BS0_complete.pdf.

377. This is pursuant to the U.K. Patent Act of 1977, which permits a patent to be endorsed with the phrase "licenses of right." Anyone can license such a patent, and if the parties disagree over the terms of the license, the disagreement is settled by the Comptroller of the Patent Office. U.K. Patent Act of $1977, \S 46$.

378. If the patentee has refused to grant a license to patents covering a proposed standard on reasonable and nondiscriminatory terms, a three-fourths vote of the membership is required to approve the standard. If the standard has already been issued when the problem arises, one-third of the members may vote to revoke the standard. ATM Forum Bylaws, art. 3.3.2.d (on file with author).

379. A standard may include patented technology "in exceptional cases" only. CEN/CENELEC Guide 8, Standardization and Intellectual Property Rights (IPRs), § 1, (ed. 1992), available at http://www.cenorm.be/boss/supmat/refdoc/mm008.htm (noting that "the policy was approved for interim use, pending the outcome of further discussions between CEN, CENELEC and ETSI").

380. Member Participation Agreement, $\S 3$ (on file with author).

381. Open GIS Consortium. OGC has now mentioned IP in their organizational bylaws, but still has no full policy. See Open GIS Consortium, Bylaws of Open GIS Consortium, Inc., $\$ \S 2.9,12.4$, (Rev. May 30, 2002), available at http://www.opengis.org/info/bylaws/20020530_Bylaws_OGC_ Final.pdf. The statement recognizes that members might contribute IP rights, and that the Directors might "from time to time" adopt rules regarding license rights, fees, etc. The Technical Committee Policies and Procedures specifies that there shall be no disclosure of proprietary information but if it is disclosed, then it is disclosed for use without restrictions, "except that no valid copyright or patent right shall be deemed to have been waived by such disclosure." Copyrights are licensed royalty-free. Open GIS Consortium, The OCG Technical Committee Policies \& Procedures, available at http://www.opengis.org/techno/pnp.pdf.

382. Proponents of a standard must notify WAP when an application is filed; other members need not do so.

383. Distributed Management Task Force. See DMTF, DMTF Technology and Patent Policy, Adopted by the DMTF October 17, 2001, available at http://www.dmtf.org/download/policies/patent10-18-01.pdf. The Board "may" authorize the patent even if it is not licensed on reasonable and nondiscriminatory terms (Patent Policy, 7.d).

384. Mobile Wireless Internet Forum. See The Mobile Wireless Internet Forum, Intellectual Property Rights (IPR) Policy Statement, Approved and Adopted April 17, 2000, available at http://www.mwif.org/ipr_policy.doc. The "RAND automatically compelled" only kicks in if there is failure to disclose. Id. $\S 6(\mathrm{~b})$.

385. Open Services Gateway Initiative. See OSG1, OSGi Member Agreement, September 22, 1999, available at http://www.osgi.org/join/memagreement.pdf; see also OSG1, Specification Licensing: Frequently Asked Questions About the Intellectual Property Terms of the OSGi Member Agreement, available at $\mathrm{http} / / \mathrm{www} .0$ gi.org/resources/spec_licensing.asp.

386. The Open Group is a federation of semiautonomous standards forums. See The Open Group, Interface Adoption Criteria, available at http://www.opengroup.org/tech/procedures/iac.htm (last updated Mar. I, 2000); see also The Open Group, Certification Programs, available at http://www.opengroup.org/tech/procedures/pop-products.htm (last updated Apr. 18, 2000) (discussing trademarks); The Open Group, Schedule 5: Trademark Usage Guide, available at http:// www.opengroup.org/registration/tmug.pdf; The Open Group, Confidentiality, available at http:// www.opengroup.org/tech/procedures/confid.htm (last updated Oct. 12, 1999).

387. While the Open Group rules do not require a search, they do require patentees to agree not to sue users of the standard for any patents that were not disclosed during the process. This has an effect analogous to a search requirement. 
388. While CommerceNet itself does not have an IPR policy, CommerceNet has spun off several standards processes that may have their own policies. Spin-offs include, for example, the Open Buying on the Internet (OBI) Consortium. OBl, Home Page, supra note 363.

389. Frame Relay Forum, Frame Relay Forum Intellectual Property Policy, available at $\mathrm{http}: / / w w w . f r f o r u m . c o m / 3000 / \mathrm{P}$ _Policy.doc. See also FRF's list of implementation agreements, which reminds the user that implementation may infringe "third party" rights. Frame Relay Forum, Implementation Agreements, available at $\mathrm{http} / / \mathrm{www}$.ffforum.com/5000/5000index.html.

390. Advanced Memory Int'l, Inc. See Advanced Meinory Int'l, Inc., Home Page, at http:// wwi.ami2.org/.

39I. Japan Electronics and Info. Tech. Industries Ass'n. JEITA, Home Page, at http://www.jeita.or.jp.

392. This policy was under construction when visited Jan. 9, 2001 and still under construction as of June 28, 2002. Japan Electronics and Information Technology Industries Association, Legal and Intellectual Property Rights Committee Website, at http://www.jeita.or.jp/lip/index_e.htm. They have a well-defined committee structure that includes committees to deal with IPR but none of their materials are publicly available. Japan Electronics and Information Technology Industries Association, About JEITA, at http://www.jeita.or.jp/english/about/commit/index.htm.

393. See ECMA, Home Page, at http://wwwv.ecma.ch/.

394. See J Consortium, IPR Policy, (Rev. 3, Mar. 13, 2002), at http://www.j-consortium.org/ ipr_final_rla.shtml.

395. JEDEC Solid State Technology Association develops semiconductor standards. See JEDEC, Home Page, at http://www.jedec.org/.

396. Organization for the Advancement of Structured Information Standards. See OASIS, Home Page, at http://www.oasis-open.org/.

397. Public Key Infrastructure Forum. See PKI Forum, Home Page, at http://www.pkiforum.org/.

398. Software Defined Radio Forum, at SDR Forum, Home Page, at http://www.sdrforun.org/; see SDR Forum, Bylaws of the SDR Forum, Inc., available at http://www.sdrforum.org/public/ sdrf_bylaws_accept_12_26_01.doc.

399. Deutsches Institut für Normung e.V (the German Institute for Standardization), available at DIN, Home Page, at http://wwwv.din.de/. See also GTW Associates, Intellectual Property Rights Policies of Selected Standards Developers May 2002, at http://www.gtwassociates.com/answers/ IPRpolicies.html. The GTW Associates website notes that the policy covers "existing proprietary rights," and that

[s]tandards shall not deal with subjects that are covered by proprietary rights. If, in exceptional cases, it is unavoidable that existing proprietary rights are affected by a standard an agreement shall be reached with the holders of such rights that is consistent with the general interest (i.e., granting of licenses on suitable terms).

Id.

400. PCl Industrial Computer Manufacturers Group. PICMG, Home Page, at http://www.picmg.com. PICMG's bylaws discuss only the IP "developed by" PICMG. PICMG-PCI Industrial Computer Manufacturers Group, Bylaws, art. XII, § 12.1 available at http://www.picmg.com/ pdf/Bylaws.pdf. However, their specification list does include a notice that Motorola had disclosed a patent pending, would specify the patents and agree to a reasonable and nondiscriminatory license. See PCI Industrial Computer Manufacturers Group, Directory of Specifications, available at http://www.picmg.org/specdirectory.stm\#_PICMG_2.20_Serial_Mesh.

401. See The Salutation Consortium, Home Page, at http://www.salutation.org/.

402. Salutation Consortium, Inc., Salutation Consortium Bylaws, $\$ 13.4 .1$, at http://www.salutation.org/whitepaper/bylaws.pdf.

403. Standards Council of Canada. See Standards Council of Canada, Hoine Page, $\mathrm{http} / /$ wwww.scc.ca/; see also Standards Council of Canada, Accreditation of Standards-Development Organizations, art. 5.8 \& Appendix 2, (Dec. 1999), available at http://www.scc.ca/publicat/ canp/ld.pdf.

404. Society of Cable Telecommunications Engineers. See SCTE, Home Page, at http:/l wivv.scte.org/. See also the SCTE's IP declarations, available at http:/www.scte.org/ standards/index.cfm?pID=38. 
405. Alliance for Telecommunications Industry Solutions ("ATIS"). ATIS has adopted ANSI's policy. See Standards Committee TI Telecommunications, Procedures Manual, (Ist ed., I3th Issue, June 2002), available at $\mathrm{ftp} / / \mathrm{ftp} . \mathrm{t}$ l.org/T1/t I-proc.pdf.

406. See Global Platform, Home Page, at http:/www.globalplatform.org/. See Intellectual Property Rights (IPR) Policy, Version 2.0, Approved 13 April 2000, Amended 17 May $200 \mathrm{I}$ (on file with author).

407. Telecommunications Industry Association. See TIA Online.org, Home Page, at http://www.tiaonline.org/. TIA follows ANSI. 